Universidade de São Paulo

Instituto de Psicologia

\title{
LEONARDO ANDRE ELWING GOLDBERG
}

Atitudes perante a morte nos websites de redes sociais: um estudo sobre o luto

São Paulo 


\section{LEONARDO ANDRE ELWING GOLDBERG}

Atitudes perante a morte nos websites de redes sociais: um estudo sobre o luto.

Versão Original

Tese apresentada junto ao Programa de Psicologia Social e do Trabalho do Instituto de Psicologia da Universidade de São Paulo para obtenção do título de Doutor.

Área de concentração: Psicologia Social Orientador: Wellington Zangari

São Paulo 
Nome do autor: Leonardo Andre Elwing Goldberg

Título: Atitudes perante a morte nos websites de redes sociais: um estudo sobre o luto

\section{COMISSÃO EXAMINADORA}

Professor Doutor Wellington Zangari

Presidente e Orientador

Departamento de Psicologia Social e do Trabalho do Instituto de Psicologia da Universidade de São Paulo (USP)

Professor Doutor Nelson da Silva Junior

Departamento de Psicologia Social e do Trabalho do Instituto de Psicologia da Universidade de São Paulo (USP)

Julgamento:

Professor Doutor Everton de Oliveira Maraldi

Programa de Estudos Pós-Graduados em Ciência da Religião da Pontifícia Universidade Católica de São Paulo (PUC-SP)

Julgamento:

Professora Doutora Ana Maria Medeiros da Costa

Programa de Pós-Graduação em Psicanálise da Universidade do Estado do Rio de Janeiro (UERJ)

Julgamento:

Professora Doutora Maria Lucia Santaella Braga

Programa de Pós-Graduação em Comunicação e Semiótica e Programa de Pós-Graduação em Tecnologias da Inteligência e Design Digital, da Pontifícia Universidade Católica de São Paulo (PUCSP)

Julgamento:

Professor Doutor Oscar Angel Cesarotto

Programa de Estudos Pós-Graduados em Comunicação e Semiótica da Pontifícia Universidade Católica de São Paulo (PUC-SP)

Julgamento: 


\section{AGRADECIMENTOS}

À Universidade de São Paulo (USP), sobretudo ao Departamento de Psicologia Social e do Trabalho (PST) do Instituto de Psicologia (IP), pela acolhida imprescindível em todos os momentos de desenvolvimento deste trabalho.

Ao Professor Dr. Wellington Zangari, que decidiu acolher o desafio de orientar um tema tão diverso com tanta parceria, contribuindo para meu crescimento na pesquisa, na profissão e na vida. Wellington foi um interlocutor presente e me privilegiou com cada comentário sobre o tema.

Aos meus pares científicos, que leram o trabalho inúmeras vezes e me brindaram com críticas e sugestões. Aos amigos que participaram ativamente, dando dicas e sugestões, compartilhando dúvidas e prestando ajuda sempre que possível.

Ao meu pai, Jacob, e minha mãe, Norma. Meus irmãos Sidnei, Flavio e Suzana. Ao analista, Roque Luiz Felipini, aos companheiros de estudos, de cartéis, de escolas de psicanálise. Aos amigos do NEPSIDIUSP.

Aos inúmeros familiares por extensão, incluindo meus pets Argos e Zelda. Esses últimos, companhias incondicionais.

Aos meus amores.

Aos queridos amigos que já se foram.

Aos membros da banca pela disposição: escolhidos com precisão para abrilhantar a reflexão. 


\section{RESUMO}

GOLDBERG, Leonardo Andre Elwing

Atitudes perante a morte nos websites de redes sociais: um estudo sobre o luto. 2019. Tese (Doutorado em Psicologia Social) - Instituto de Psicologia, Universidade de São Paulo, São Paulo, 2019

Nessa tese, pretendeu-se examinar as atitudes perante a morte a partir do advento dos websites de redes sociais (WRS's), o que se desdobrou em uma pesquisa também sobre luto, a morte e o campo digital. A estrutura do trabalho envolveu a apresentação do fenômeno na internet: dos cemitérios virtuais às tumbas digitais que habitam o Facebook. Seguiu-se então uma revisão bibliográfica de autores que trabalharam com o tema e de reflexões sobre a questão da identidade no ciberespaço, teorias do conhecimento sobre a morte, psicologia da morte e sobre o luto. Tais temas perpassaram autores da Psicologia, Psicanálise, Antropologia e História. Depois de tais reflexões teóricas, foi apresentada uma análise de dados oriundos de um questionário aplicado na internet, que contou com 173 respostas, além de duas entrevistas realizadas com enlutados. Alguns temas que emergiram evidenciaram a preponderância da interação com perfis de falecidos entre os enlutados, destacando os websites de redes sociais como elemento partícipe do rito fúnebre contemporâneo e consequentemente do luto. Nas considerações finais alguns pontos que concernem aos paradoxos de uma atitude perante a morte e do luto nos WRS's foram elencados. Além disso, a pesquisa suscitou discussões que que se referem à Psicologia da Morte e também à intersecção entre a Psicologia e o Campo Digital.

Palavras-chave: Redes Sociais. Psicologia da Morte. Psicologia Social. Luto. 


\begin{abstract}
GOLDBERG, Leonardo Andre Elwing

Attitudes towards death on social networking websites: a study on mourning. 2019. Thesis (Doctorate in Social Psychology) - Institute of Psychology, University of São Paulo, São Paulo, 2019

In this thesis, it was tried to examine the attitudes toward death from the advent of Social Networking Websites (SNW's), which was unfolded in a research also on mourning, death and the digital field. The structure of the work involved the presentation of the phenomenon on the internet: from virtual cemeteries to digital tombs that circulate on Facebook. This was followed by a bibliographical review of authors who worked on the theme and of reflections on the question of identity in cyberspace, theories of knowledge about death, the psychology of death and about mourning. These themes permeated authors of Psychology, Psychoanalysis, Anthropology and History. After such theoretical reflections, an analysis of data from a questionnaire applied on the internet was presented, which included 173 responses, as well as two interviews with mourners. Some themes that emerged evidenced the preponderance of the interaction with profiles of deceased among the mourners, highlighting the social networking websites as a participant in the contemporary funeral rite and consequently of mourning. In the final considerations some points that concern the paradoxes of an attitude towards death and mourning in the WRS's were listed. In addition, the research elicited discussions that refer to Psychology of Death and also to the intersection between Psychology and the Digital Field.
\end{abstract}

Keywords: Social Networks. Psychology of Death. Social Psychology. Mourning 


\section{SUMÁRIO}

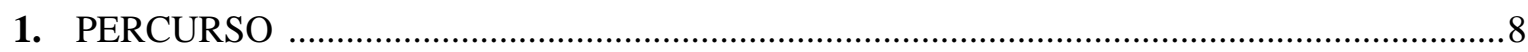

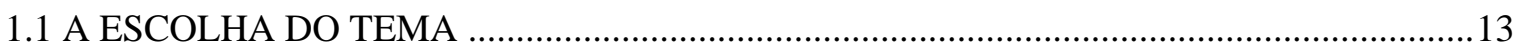

2. DELIMITANDO O OBJETO: OR RITOS FÚNEBRES NO CIBERESPAÇO E NOS WRS'S

2.1 DOS CEMITÉRIOS VIRTUAIS AS TUMBAS INTERATIVAS DIGITAIS .........................18

2.2 DAS IDENTIDADES AOS MODOS DE SUBJETIVAÇÕES DIGITAIS ...............................26

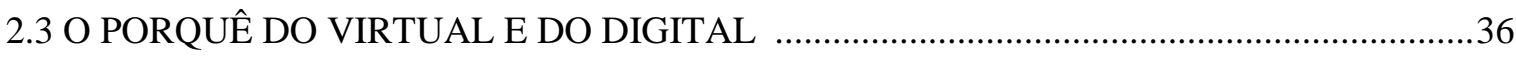

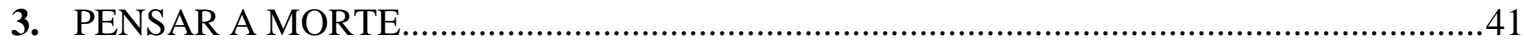

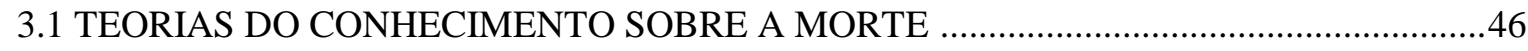

3.2 UMA PSICOLOGIA DA MORTE OU PARA A MORTE …................................................48

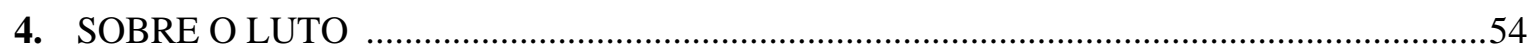

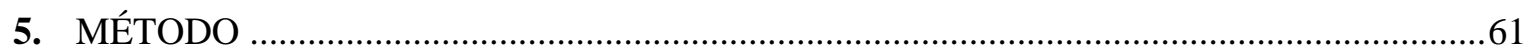

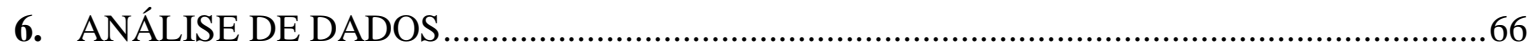

6.1 DUAS ESCUTAS SOBRE A QUESTÃO: ENTREVISTAS COM ENLUTADOS ................98

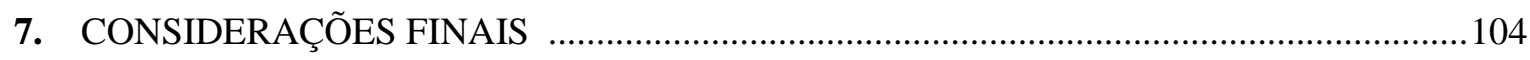

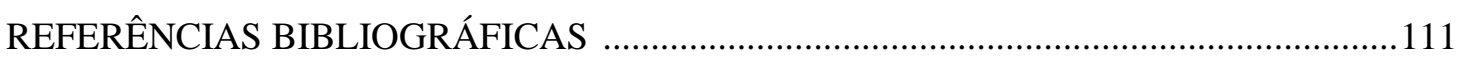

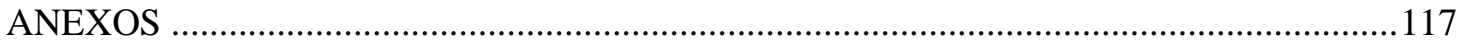


... Quanto à frase derradeira há versões variadas...

Segundo um trovador do mercado, passou-se assim:

"No meio da confusão

ouviu-se Quincas dizer:

'Me enterro como entender

Na hora que resolver.

Podem guardar seu caixão

Pra melhor ocasião.

Não vou deixar me prender

Em cova rasa no chão’.

E foi impossível saber

o resto de sua oração"

A Morte e a Morte de Quincas Berro d'Água

Jorge Amado (2008) 


\section{Percurso}

Nesse capitulo, falarei um pouco do percurso que trilhei e de algumas reflexões levantadas a partir do trabalho de pesquisa e de minhas inquietações. Além disso, introduzirei algumas considerações ao leitor relativas ao tema proposto.

Formei-me em Psicologia em 2011 e meu trabalho de conclusão de curso fora sobre o conceito de sadomasoquismo e sua intersecção com programas televisivos de concursos musicais. O que me incomodava na época eram as cenas de chacota das quais determinados participantes se submetiam em programas televisivos que se propunham, em tese, a encontrar novos ídolos musicais. Estabeleci então uma reflexão sobre a ideia de unidade dialética do conceito de sadomasoquismo em Freud e a desconstrução que Deleuze faz de tal unidade a partir da literatura. Realizei então uma análise sobre a participação de voluntários de tais programas sob a égide de um contrato - contrato esse elaborado pelas produtoras televisivas, no qual o conteúdo autoriza a exposição dos candidatos a situações vexatórias - e estabeleci algumas construções teóricas para pensar no que motivava tal espetáculo.

Depois de concluído, comecei a clinicar e a estudar mais intensamente a teoria psicanalítica em Freud e Lacan. Depois de um semestre, quis continuar a pesquisa, mas ao invés de pensar nos programas televisivos, decidi me concentrar na ascensão do conceito de Websites de Redes Sociais (WRS's), mais especificamente o Facebook. Comecei a trabalhar com a questão dos WRS's a partir do projeto de pesquisa do Mestrado. Ingressei no programa de Educação, Arte e História da Cultura da Universidade Presbiteriana Mackenzie (UPM), na linha de pesquisa sobre novas tecnologias e tive a intenção inicial de continuar a pesquisa sobre programas televisivos, mas decidi enveredar para as redes sociais a partir da hora que percebi o impacto cotidiano, político e a crescente social do Facebook. Fui orientado na ocasião pelo Professor Doutor Wilton de Azevedo, que trabalhava muito com o conceito de expansão da escritura na ambiência digital, e pude participar do início das reuniões do LHUDI (Laboratório de Humanidades Digitais) no próprio Mackenzie. Minha dissertação foi uma espécie de releitura do conceito de sociedade do espetáculo, de Guy Debord, a partir do funcionamento dos WRS's. Para tal proposta, fiz uma incursão em teóricos como Marx, Hegel, Freud, Lacan e Bauman, para repensar conceitos que eu considerava fundamentais para compreender tais mecanismos: reconhecimento, desejo, espetáculo. A dissertação foi elaborada em meio ao conturbado ano de 
2013, e a produção de imagens que circularam nos WRS's foi fundamental para reflexões sobre conteúdos que "viralizavam" sem quaisquer crivos que verificassem a procedência das informações que eram compartilhadas, algo análogo a invenção do conceito de pós-verdade depois das eleições norte-americanas de 2016. A banca que compôs minha defesa contou com a Professora Doutora Margareth dos Reis e com a filósofa e Professora Doutora Márcia Tiburi.

A partir da defesa, e pensando em algumas colocações da Professora Márcia e do meu orientador, Prof. Wilton, decidi continuar a minha pesquisa sob um outro viés, que eu considerava algo diferente, que me estarrecia. A emersão de tal tema me causou algo entre espanto e estranhamento, e trabalha-lo se tratava mesmo de uma urgência subjetiva. Acontece que percebi, por amigos e amigos em comum, que muitas pessoas que faleciam deixavam para trás esse perfil "virtual", que eu considerava uma espécie de "arquivo de linguagem", e que mais tarde me depararia com o conceito de legado digital. Aquilo que o falecido deixa nos WRS's depois de sua morte e como os vivos, enlutados ou não, encaravam a dinâmica do perfil, a ideia de morte e do luto me intrigavam. A partir da questão inicial do meu mestrado, que era, em última instancia, sobre o que se transforma a partir dos WRS's em termos de relacionamentos humanos; pensei que essa ideia de um perfil "virtual" que continuasse, por vezes sendo manipulado por familiares e amigos, poderia se tratar de uma espécie nova de atitude perante a morte, para parafrasear Freud em seu texto de 1915, "Considerações atuais sobre a guerra e a morte" 1 .

Diante dessa questão, que se fazia presente a cada morte de algum conhecido, a cada perfil que continuava "circulando" nas redes sociais, sem necessariamente que alguém estivesse sob o seu comando, mas simplesmente pela programação automática, decidi que era hora de delimitar um projeto para minha pesquisa na tentativa de ingressar em um programa mais especifico de Psicologia. Prestei então o processo seletivo do programa de Doutorado em Psicologia Social do Instituto de Psicologia Social da Universidade de São Paulo (IPUSP), com um projeto ainda em construção, mas fechando a minha questão de pesquisa no que concerne à intersecção entre morte e Websites de Redes Sociais (WRS's).

Foi na ocasião que conheci o meu atual orientador, o Professor Doutor Wellington Zangari, que me acolheu na compreensão da demanda da tese, da pesquisa, dentro da própria dificuldade de trabalhar com um tema que de antemão já implicaria uma pesquisa interdisciplinar: que recorre à conceitos da psicologia mas também da história, antropologia, da cibernética, de linguagem

\footnotetext{
${ }^{1}$, no subtítulo Unser Verhaltnis zum tode: "Nossa atitude perante a morte".
} 
e escritura, em permanentes diálogos e intersecções que só encontrariam terreno na possibilidade de abertura para o "desconhecido". Quando trabalhamos sobre as atitudes do homem perante a morte, o diálogo com o programa de "Psicologia Social da Religião" e do comportamento religioso do humano é enriquecedor e um constante aprendizado. O desafio de manter um recorte de pesquisa e acompanhar a velocidade de novas pesquisas sobre o tema, novos softwares e dos movimentos na rede de programas específicos para usuários já falecidos, assim como dos anseios dos usuários em geral sobre a questão, fizeram com que eu decidisse, junto ao meu orientador, estabelecer como foco do trabalho o website de rede social Facebook para coleta de dados e análise. Em 2015, ano do meu ingresso no programa, publiquei um trabalho embasado em meu projeto, denominado: Perfis póstumos nas redes sociais, na Revista Filosofia Ciência e Vida, que já organizava ao menos um caminho teórico no qual eu pretendia me ancorar.

Um dos grandes desafios na elaboração da tese de doutorado diz respeito ao estabelecimento de um objeto e do recorte da pesquisa: delimitar um campo de pesquisa em um terreno arenoso que se refere à uma Psicologia Social da Morte, mas também à uma Psicologia Social que se preocupe com a emersão de um Campo Digital.

A questão se tratava justamente em pensar como uma Psicologia pode tratar as transformações da cultura sem que se derive para uma Antropologia da Morte, dos costumes ou uma pesquisa em História. O que tentei fazer foi levar em conta tais considerações teóricas para retornar à escuta das pessoas enlutadas e como elas encaram tal questão.

Porém, ao mesmo tempo precisamos pensar não só a partir do efeito de tal dinâmica nos websites de redes sociais, mas também refletir qual atitude do sujeito diante das redes sociais no que concerne à ideia, ou à imagem da morte - afinal a morte é sempre vicária, algo que tratarei mais a frente - e em última instância, recorremos à preocupação que influenciou tanto o trabalho historiográfico de Philippe Ariès (2012) quanto o próprio Freud (2010), sobretudo em um momento que se referia à Primeira Guerra Mundial, no texto "Considerações atuais sobre a guerra e a morte", escrito em 1915. Em tal texto, o segundo subtítulo se descreve como "Nossa atitude perante a morte", no qual Freud estabelece uma reflexão sobre tal atitude. Em outras palavras, é preciso tratar do que pensamos como a morte do outro ou a ideia da própria morte antes de averiguar os efeitos de uma transformação cultural em atitudes daqueles que se deparam com a ideia da morte nas redes sociais. 
Penso que a dificuldade é análoga a de Philippe Ariès, o historiador que teceu um percurso sobre a história da morte no ocidente em texto com título homônimo, e descreveu em seu prefácio de uma reedição, escrito em 1975, sobre a dificuldade de estabelecer um objeto e uma especificidade na atuação do historiador da morte, no que se refere à diferença em relação ao historiador da religião; e pondera sobre seu difícil trabalho como: "pesquisas e meditações sobre as atitudes diante da morte em nossas culturas cristãs ocidentais" (Ariès, 2012, p. 18). O historiador então expõe seu interesse e enfoque sobre essas "atitudes diante da morte", em uma expressão semelhante à adotada por Freud, porém a partir de uma perspectiva da pesquisa em história: dos costumes, documentos, dos cemitérios, dos túmulos, dos rituais fúnebres. Mas a partir da coleta dos arquivos, o desafio seria, para o historiador da morte, decifrar tais documentos em uma análise descolada da concepção dos historiadores da religião, e mais aproximada da tentativa de pensar a atitude cotidiana diante da morte, “[...] o fundo banal de representação comum que era inteligível ao público [...]" (Ariès, 2012, p. 27). Ou seja, a intersecção da linguagem que unia tanto clérigos letrados quanto o público comum. Por muitas vezes, o presente trabalho esteve diante de uma dificuldade semelhante: como estruturar uma pesquisa que se proponha a pensar nas atitudes perante a morte e ao mesmo tempo manter a proposta inicial de uma tese em Psicologia Social? Ou, como extrair dados analisáveis de uma experiência tão singular que é a do luto e da lida com a ideia da morte sem derivar para uma pesquisa puramente historiográfica?

O leitor se deparará ao longo da tese com referências teóricas diversas, aparentemente distantes, encontradas no esforço de dar conta desse paradoxo. Ao tratar do luto a partir do advento dos websites de redes sociais, me vi lançado na difícil tarefa de dar conta de dois campos de pesquisa tão complexos quanto vastos: de um lado, pensar o sujeito que interage no campo digital; por outro, pensar na ideia de morte e todas as implicações que os conceitos sobre a morte e o morrer implicam. Sobre o campo digital, participei da criação em 2018 do NEPSIDI (Núcleo de Estudos em Psicologia e Campo Digital), no Instituto de Psicologia da Universidade de São Paulo (IPUSP), junto à colegas que se interrogavam da mesma maneira sobre o papel da Psicologia em pensar tal campo, e se poderíamos considerar um campo efetivamente novo, de pesquisa e pratica clínica. Em esforço conjunto de criar um território teórico comum, percorremos autores da Comunicação e da Psicologia que tateavam o tema. A inspiração dos capítulos que trabalharam diretamente sobre a questão das subjetivações nas redes sociais foi precisamente evocada em nossas produtivas conversas. 
E por que o Facebook? Diante do agigantamento possível, da própria dificuldade de estabelecer um recorte específico - poderíamos considerar até as redes sociais offline no trabalho - decidi adotar como referência para a construção teórica e a análise o maior website de rede social (WRS) existente, o Facebook.

Porém, ao mesmo tempo em que o próprio Facebook transforma sua maneira de lidar com a morte ${ }^{2}$, surgem diversos outros aplicativos com a proposta de estabelecer memoriais e tentativas de fabricar linguagens possíveis para uma espécie de continuidade digital.

Tais aplicativos serão citados ao longo da pesquisa; mas é interessante pensarmos na atualidade da demanda: de um objeto que se transforma de maneira acelerada e que reinscreve a pesquisa em Psicologia e Campo Digital em uma práxis e responsabilidade, um atravessamento, em uma ética dos possíveis, indispensável para trabalharmos sobre as atitudes humanas perante a morte em um contexto especifico e em um terreno que se transforma de forma mais veloz que as pesquisas que os acompanham.

O percurso que farei, a partir de agora, irá se debruçar primeiro sobre a emersão do tema e autores que já trabalharam com esse específico recorte, restrito ao campo digital e à questão da morte no ciberespaço. Depois, refletirei sobre desdobramentos teóricos que concernem a disciplinas que interessam à pesquisa: Psicologia Social, filosofia, antropologia, história e campo digital.

Após tais reflexões, irei discorrer sobre um questionário aplicado através da plataforma Survey Monkey, oriundo de inspiração metodológica que usou como referência as pesquisas do Professor Jed Brubaker, para pensar características próprias e diferenciais entre as atitudes perante a morte nos WRS's e ritos fúnebres contemporâneos e tradicionais, além de apresentar duas entrevistas sobre o tema. As análises são apresentadas em diálogo com os capítulos teóricos e entre os temas que emergiram e se aproximam. No último capítulo, serão apresentadas algumas considerações finais sobre os dois eixos estruturantes do trabalho: as atitudes perante a morte nos websites de redes sociais e a questão do luto a partir do advento dos mesmos.

\footnotetext{
${ }^{2}$ No início, a rede social deixava apenas duas opções para o perfil de um falecido: exclusão ou continuação na rede. Hoje, o usuário pode determinar uma outra conta como "herdeira digital" para decidir sobre após sua morte. Se a rede é avisada sobre o falecimento de alguém, através de contato familiar, também é possível transformar o perfil em uma página memorial (em memória), que não pode mais ser atualizada ou interagir com outras.
} 


\subsection{A escolha do tema}

A escolha do tema perpassa outros tempos: ainda enquanto profissional recém-formado, quando comecei a construir um percurso em pesquisa no mestrado, meu projeto ainda não interrogava os websites de redes sociais. Na realidade, o que me encucava já enveredava pelos caminhos que refletem sobre a noção de morte. Meu projeto inicial se propunha a pensar sobre Arthur Bispo do Rosário para além da denominação de artista. A partir do momento em que eu me deparei, na Bienal de São Paulo, com seu Manto, sua opus Magnum, acompanhada da explicação de que toda sua obra deveria ser enterrada com o Bispo, por desejo próprio, mas que em determinado momento fora considerada em seu estatuto artístico, e então cooptada por um discurso diferente do seu, à dizer, o místico, tal ideia me suscitou algumas questões: um psicótico que adota toda uma narrativa religiosa para lidar com sua obra perderia seus direitos sobre a mesma? Mais que isso, o desejo de um moribundo, e propriamente de um morto, deveria ser simplesmente suplantado a partir do momento em que seus objetos são considerados valiosos para o mundo da arte?

Os desdobramentos de tais questões geravam caminhos infindáveis. Porém, o que eu considerava interessante e urgente, era realizar que a partir do momento em que uma religião passasse a ser considerada uma mitologia - individual ou coletiva - suas obras sacras eram cooptadas pelo discurso, pelas teorias da arte. E, não obstante, restaria ao desejo de um morto um valor esvaziado, sobretudo se o morto também fosse considerado um louco, o que fica evidenciado na obra de Arthur Bispo do Rosário e nas construções teóricas que a acompanham e claudicam entre o discurso artístico, religioso e psiquiátrico. Eu me deparava nesse momento com a questão da morte e os ritos que a acompanham.

A eleição dos perfis de falecidos nos websites de redes sociais não fora ao acaso. Além de amigos falecidos, alguns muito queridos, e também amigos de amigos, passei a perceber como tais perfis eram alimentados com narrativas diferentes, sobretudo por familiares estarrecidos. As primeiras questões que me vieram em mente concerniam à localização temporal de tal fenômeno, se se tratava de algo novo ou não na história da humanidade. Outra questão remetia à própria função da escrita/escritura: se sua função implicava em derrogar a ausência, ou em fazer presente aquele que não está, como poderíamos pensar em uma plataforma que conserva a escritura do falecido e, de alguma forma, permite que seus interlocutores sigam interagindo 
com tal arquivo, que insiste em se fazer presente? Afinal, se tratamos da morte e de nossa lida com ela, falamos de um jogo de presença e ausência.

É a partir dessa questão também que me interessei em como história circunscreve a relação entre a morte e a escritura: no antigo Egito, a eternidade dependia de uma série de escrituras levadas pelo morto para o além, para o instruir a se comportar, dizer as palavras certas e até sobre as regras de etiqueta que deveriam ser cumpridas no Reino dos Mortos, um verdadeiro ritual. No período que compreendia o Antigo Império (2705-2213 a.C.), os textos sagrados com tais instruções eram gravados para a realeza em seus próprios túmulos. No chamado Primeiro Período Intermédio (2213-2061 a.C.), a baixa nobreza já gravava em seus ataúdes de madeira os escritos das fontes sagradas. Já no começo do Novo Império (1560-1070 a. C.), a busca pela eternidade já se estendia a boa parte dos egípcios, que colocavam o Livro dos Mortos - a reunião de instruções para se livrar das adversidades da vida no outro mundo - enterrados junto ao falecido com tais conjuros inscritos em seus sudários de linho ou em rolos de papiro (Sanchez, 2007, p. 151).

Uma cópia pessoal do Livros dos Mortos era parte de uma viagem empreendida de forma eficaz para o além: um conjunto de instruções que deveriam ser pronunciadas no momento e da forma certa servia como uma apólice que resguardava a vida eterna do falecido (Sanches, 2007, p. 148), em um ritual no qual a continuação da vida dependia da escritura.

A questão da morte sempre esteve intimamente ligada ao desenrolar da lida humana com a escrita. As escritas mais antigas se referem a tábuas de argila queimadas, que indicavam contabilidade, na Mesopotâmia (mais ou menos 3300 a.C.). E, no Egito, sinais usados para registrar precisamente os bens dos mortos em seus túmulos (cerca de 3200 a.C.). Apesar das incertezas, entre os primeiros sinais na Mesopotâmia, do Egito e da China, estão os chamados pictogramas (Robinson, 2016, p. 17).

Os pictogramas, ou escritura pictórica, são imagens com um baixo grau de abstração, em que figuras como animais representam animais, o Sol ele próprio, e assim respectivamente, “[...] um homem desenhado com pauzinhos pode significar, por exemplo, qualquer coisa entre um indivíduo e toda a humanidade; também pode simbolizar "ficar de pé", esperar", "sozinho", "solitário" ou até mesmo "banheiro masculino" (Robinson, 2016, p. 19). A escritura pictórica continua sendo representada em sinais de trânsito e de sinalização em lugares públicos ainda hoje, por exemplo. 
E creio que poderíamos definir parte dos famosos emoticons - as sequencias tipográficas representadas por uma imagem - tão em voga no WhatsApp, no Facebook e em outras plataformas de comunicação digital, como formas de escrita pictórica. Apesar de alguns autores considerarem tais imagens uma outra categoria, determinados emoticons se tratam exclusivamente e precisamente de escritura pictórica. Estaríamos enveredando para uma comunicação com o código empobrecido, sempre mínimo?

Porém, e esse talvez seja o ponto que mais tenha influenciado a escolha por uma tese organizada da maneira que está: além de me interrogar sobre a intrincada e dialética relação entre tecnologia/escritura/imagem e morte, passei a considerar o que de fato interessaria à uma tese de Psicologia. Afinal, para além de todas as questões lógicas, ontológicas, metafísicas e históricas que tal dialética pode suscitar, passei à considerar importante seu desdobramento mais direto: quais eram os efeitos de tais "tumbas interativas digitais", de tais memoriais de escrituras interativos contemporâneos sobre o luto e sobre a forma que poderíamos pensar no contemporâneo? Ou, efeito nenhum? Para isso, além de examinar o que diversos saberes poderiam dizer sobre os temas, depois de um exame de qualificação com sugestões preciosas, decidi que seria também preciso ler e escutar as pessoas que vivenciam tal dinâmica.

Mais um ponto: além de lidar com o fenômeno de forma curiosa, também fui atravessado pela morte de dois amigos muito queridos nesse interim. Um deles, inspiração no tema das redes sociais, Wilton de Azevedo, que fora meu orientador no Mestrado, e que deixou bem destacada a implicação de como a escrita pode ter um valor bem preciso no ato do luto. Um de meus trabalhos, publicado durante o desenrolar da tese, fora um artigo em homenagem ao mesmo, que tratou de forma enfática a questão da palavra enquanto matéria, que inseriria Wilton em uma tradição que, de Demócrito à Lacan, encara tal materialidade como princípio fundamental. Nesse sentido, o artista, análogo ao carpinteiro - como Demócrito chama Homero - construiria um mundo de acordo com a ordenação das palavras.

E outro, um querido amigo de meu cotidiano que se foi muito cedo, de forma acidental e rasgante, e que me entristeceu em muito. Em ambos os casos, encontrei certo afago quando abri mensagens antigas, áudios e imagens que reapresentavam meu contato com eles. Senti, em determinados momentos, que alguma forma de presença se fazia quando eu percorria alguma dessas "memórias concretas" e as fazia falar: uma espécie de convocação bem-sucedida.

Se a lembrança, outrora, poderia ser acessada apenas por escrita e imagem, agora dispomos de verdadeiros arquivos interativos que compreendem imagem, áudio, fotografias e vídeos de 
nossos mortos. O esquecimento imagético já não é tão simples. Se toda fotografia é também de si, se a fotografia conserva o punctum, bem descrito por Barthes, todo arquivo, sobretudo na facilidade com a qual pode ser acessado no meio digital, é uma experiência de revisitar outra experiência, é um tantinho de madeleines que trata de convocar um tempo que já se foi.

Assim nasceu a ideia de encontrar alguma forma de escutar outras pessoas que experimentaram o luto nesse momento em que grande parte da população conserva um perfil nas redes sociais. Depois da qualificação de meu projeto, em que os professores que compunham a banca fizeram ricos apontamentos sobre o quão interessante poderia ser, para além de oferecer uma leitura teórica do fenômeno, escutar outras pessoas que passaram por isso, decidi também estabelecer um questionário. Falarei um pouco sobre a inspiração metodológica e a definição de temas e perguntas do questionário no capítulo sobre método. 


\section{Delimitando o objeto: os ritos fúnebres no ciberespaço e nos WRS's}

\section{Si vis vitam, para mortem}

O Facebook, desde o seu lançamento, atingiu tamanho número de usuários e intensidade em interações que já faz parte do cotidiano do mundo, ao menos no ocidente. Os usuários compartilham questões cotidianas: fotografias, feitos, marcos, sentimentos, afetos; tudo o que couber em um formato de imagem, áudio, texto ou vídeo, na chamada linha do tempo.

Os perfis do usuário são alimentados por fotografias, textos, vídeos e áudios em pretensa ordem cronológica, o que transforma a ferramenta em uma história editável. A plataforma, através da programação, realiza diversos "chamados" para estimular a interação entre os usuários. Entre eles, alguns chamados que se propõe a vivenciar memórias em conjunto e assim reconectar antigos amigos. Tal conteúdo e chamados, mesmo depois da morte do usuário, continua. $\mathrm{Ou}$ seja, os usuários vivos se deparam com os perfis de usuários já falecidos - se estes se mantiverem ativos - em modalidades como "sugestão de amizade" ou em evidência em datas como aniversários ou "comemoração de amizade", ou então de "comemoração de acontecimentos" na rede, através de fotos em conjunto ou de vídeos automáticos criados pela própria plataforma. A ideia do Facebook é que seus usuários se mantenham em interação permanente.

Diante do incômodo de grande parte dos usuários que se deparavam com os perfis de falecidos, o Facebook decidiu, em 2014, atender a demanda e criou as páginas memoriais: uma derivação do perfil tradicional na qual o perfil do usuário já falecido se estagna, não pode mais receber mensagens nem ser atualizado, e também sai da programação automática, já não aparece em datas comemorativas ou em anúncios do website.

Porém, grande parte dos familiares e amigos dos usuários falecidos optam por manter o perfil do usuário como ele deixou; em uma espécie de decisão ética no que se refere ao legado digital do falecido. Tal decisão deve ser tomada por um usuário designado pelo falecido - o que pode ser realizado nas configurações de qualquer conta - o contato herdeiro.

De acordo com a página informativa do Facebook: O que acontecerá com a minha conta se eu falecer? (2018), os usuários da rede social devem indicar um contato herdeiro: aquele que a partir do momento em que o usuário falece, deve escolher entre transformar a página em 
memorial ou exclui-la da rede. Tal usuário também terá a opção de baixar todas as informações contidas na conta do falecido, uma espécie de backup de informações digitais do morto.

Se o usuário decide transformar a conta em uma página memorial, tal perfil não aparece mais nas sugestões ou lembranças, "Os perfis transformados em memorial não são exibidos em espaços públicos, como nas sugestões do recurso Pessoas que você talvez conheça, em lembretes de aniversário ou anúncios" (Facebook, 2018). Assim, passa a parar de interagir com os outros usuários através da programação automática.

Sem ter designado um contato herdeiro, o Facebook estabelece que apenas membros da família ou o advogado titular da família devam enviar "uma foto ou uma digitalização da certidão de óbito do seu ente querido" (Id. 2018), para assim, superando a burocracia, excluir ou transformar a página em memorial.

\subsection{Dos cemitérios virtuais às tumbas interativas digitais}

Embora as atitudes perante a morte e o luto no Facebook chamem a atenção de pesquisadores, sobretudo dos que trabalham com Comunicação e Sistemas de Informação, os cibermemoriais (ou webmemoriais) e os cemitérios virtuais existem há muito tempo na internet.

O The World Wide Cemetery ${ }^{3}$, mais antigo em funcionamento, data de 1995. Seus memoriais têm homenagens a usuários falecidos do mundo inteiro, e podem ser publicados em 6 línguas, inclusive português. Os usuários podem visitar os memoriais e deixar flores "virtuais" aos mortos ou publicar uma mensagem.

Em 2000, um artigo sobre o tema realizou um levantamento de três grandes webmemoriais de cemitérios virtuais e chegou a conclusões que chamaram a atenção da literatura sobre morte e luto: Roberts e Vidal (2000) perceberam que a maioria das mortes eram recentes, mas $7.3 \%$ tinham ocorrido mais de 20 anos antes das postagens. A maioria dos memoriais eram endereçados à comunidade, mas $28.3 \%$ eram escritos para o morto. Apesar de a maioria dos memoriais escritos se tratarem de histórias de celebração, alguns outros temas foram encontrados: saudades do falecido, narrativas sobre a circunstância da morte e também culpa.

\footnotetext{
${ }^{3}$ Cf. https://cemetery.org/about/
} 
Robert e Vidal (2000) também apontaram como tais webmemoriais serviam como espaços privilegiados para pesquisadores acessarem escritos pessoais sobre luto durante essa fase, e que uma questão pertinente seria pensar que tipos de benefícios escrever publicamente para e sobre o morto poderiam trazer para os usuários de tais plataformas.

Em outra publicação sobre de que forma os webmemoriais afetavam os enlutados, Roberts (2004) discorre sobre a função social de tais plataformas e sugere então que elas podem ser o gatilho de um senso de comunidade entre os enlutados que as utilizam. Fala sobre a conexão que os enlutados podem formar a partir de um senso psicológico de comunidade que pode ser mais facilitado que os de interação face-a-face.

Brubaker et al. (2013) encontram mais tarde uma situação análoga em relação aos grupos de Facebook que se formam a partir da morte de um usuário, nos quais os usuários se deparam com narrativas diferentes sobre um mesmo falecido.

Ambas pesquisas incorrem em uma questão que importa tanto aos pesquisadores da morte quanto aos antropólogos: a função comunal do rito, central no que se refere à antropologia da morte.

Louis-Vincent Thomas (1996), ao prefaciar um texto de Jean-Pierre Bayard, relembra da rapidez dos funerais modernos, que se distanciam da ideia da necessidade do ritual fúnebre. Reunindo fundo e forma, o rito corresponde a uma determinada função social; ancorado no mito, quando cumprido pela comunidade, pelo coletivo, é eficaz em produz um efeito tranquilizador, e "[...] é por causa desse poder estruturador e tranquilizador que a ele recorremos quando deparamos com uma situação nova e aleatória" (Thomas, 1996, p. 8).

Thomas (1996, p. 16) sublinha a função comunal do rito e a destaca como uma fragilidade própria de nosso tempo. Afinal, essa mobilização comunitária, essa resposta à ruptura da morte através de uma continuidade coletiva, ofereceria um grande valor terapêutico. Além disso, o grupo encontraria coesão e bradaria por continuidade de forma regenerada, quando um dos seus falece, assim como o autor (Id, Ibid.) testemunha em funerais africanos. Essa questão aparecerá com ênfase no momento em que descrevo a pesquisa de Jed Brubaker et al. (2013) como inspiração metodológica de meu trabalho. Também falarei sobre questões que concernem ao rito fúnebre no contemporâneo a partir da Psicologia Social da Morte.

A função do rito comunal no ciberespaço é um apontamento interessante que aparece em ambas pesquisas supracitadas. Porém, é também desses diálogos que se sirvam de uma antropologia 
da morte que a literatura em torno dessa temática carece, especificamente em pesquisas que se amparam unicamente em dados quantitativos, como a de Roberts e Vidal (2000).

Além dos webmemoriais, também nos deparamos com websites com o objetivo de registrar um memorial para pessoas comuns, mortas em acontecimentos históricos específicos: nessa categoria encontramos os museus do Holocausto, com um trabalho intenso de registro das vítimas do nazismo (Yad Vashem www.yadvashem.org.il e Museu Americano Memorial do Holocausto http://www.ushmm.org/), o memorial de soldados americanos mortos na guerra do Vietnam (http://www.thevirtualwall.org/), além de inúmeros outros, cada um correspondente à um evento especifico (Walter et al., 2016).

Precedido pelos webmemoriais e outras formas de registro destinados propriamente a esta finalidade, o advindo dos Websites de Redes Sociais (WRS's) como conhecemos hoje se popularizou com plataformas como o Orkut e o MySpace, em meados dos anos 2000. A questão da morte de seus usuários, consequência óbvia dessa migração digital, também gerou literatura específica.

Sobre o MySpace, Brubaker e Hayes (2011) realizaram um estudo envolvendo 205.068 comentários postados em 1.369 perfis de usuários que tinham falecido, apontando para uma espécie de "amplificação" de padrões existentes fora do ciberespaço, como lembranças em datas memoráveis ou sagradas, atualizações de eventos cotidianos e manutenção de uma relação com os perfis dos usuários falecidos, como por exemplo, aparece em uma das passagens recordadas: "I know people read these comments and think I am weird to post stuff like this, but is the only way I feel like I can still connect" (Id. Ibid.).

Brubaker e Hayes (2011 apud Brubaker, 2013) encontraram um forte padrão de mensagens postadas nos perfis dos mortos diretamente ao morto. Citando um dos participantes, que relata ter se deparado com essa fala diretamente direcionada para o morto "I just remember a loto $f$ people saying 'I will miss you forever. I can't believe you're gone' like speaking to somebody versus about somebody".

Algumas pesquisas também se referem à questão dialética entre o público e o privado nos WRS's entre os adolescentes, como Boyd (2007), que fez um levantamento de como as redes impactavam na vida social e os dilemas afetivos de adolescentes americanos.

O Facebook, talvez pela intensidade que atravessou o cotidiano no ocidente, talvez pelo número de usuários, que em 2018 chegou à 2 bilhões ao redor do mundo, passou a exercer papel central 
em questões relativas ao social, ou propriamente à cultura. $\mathrm{O}$ que também fez com que pesquisas com diferentes recortes abordassem a questão da morte em sua plataforma.

Tama Leaver e Tim Highfield (2016) levantam uma questão interessante que remete ao sujeito: ao fazerem um levantamento das hashtags \#ultrasound e \#funeral no Instagram, examinaram imagens e escritos que se referem à sujeitos que estão por vir e suas malhas socio simbólicas (os bebês que ainda não nasceram) e também sobre a questão do luto que envolve postagens sobre a morte de alguém querido. Constataram um dado interessante: diferentemente do uso de outras plataformas como o Facebook, no Instagram não existem tantas postagens que falam sobre o falecido ou alguma data comemorativa que remeta a ele. Pelo contrário, nessa rede social em que a imagem é preponderante, o que se compartilha sobre o luto concerne à uma dor pessoal dividida com os outros usuários. Na conclusão dos autores, seria difícil estabelecer uma aproximação entre as postagens sobre nascimento e morte especificamente no Instagram. Cada afeto é tratado de forma diferente de acordo com a rede social, suas preponderâncias, possíveis, limites e estrutura.

DeGroot (2014) refletiu sobre os usuários que não eram tão íntimos dos falecidos e que se deparavam com grupos criados pelos enlutados. Alguns recortes também articulavam teorias da identidade, sobretudo influenciados por uma tradição da ego psychology norte-americana, além de serem mais trabalhados por pesquisadores da ciência da computação e de comunicação e mídia que especificamente tanatologistas ou psicólogos (Walter et. al. 2016). A questão do grupo, ou da organização comunal entorno dos enlutados, aparece também de forma intensa, dos webmemoriais aos WRS's, quando falamos especificamente do Facebook.

Uma pesquisa dinamarquesa, baseada em páginas criadas para lembrar de 6 jovens mortos em casos noticiados pela mídia, analisou 1015 comentários deixados por usuários em páginas com mais de 5 mil seguidores. RIP pages são páginas criadas exclusivamente para compartilhar lembranças e prestar homenagens a um morto. Não é uma prática comum em relação aos usuários brasileiros, mas a pesquisa com o público dinamarquês realiza conclusões interessantes: $24 \%$ dos comentários foram direcionados diretamente para o morto (você...) e apenas $11 \%$ se referiram ao morto em terceira pessoa. A maioria escreveu RIP (rest in peace em inglês ou requiescat in pace em latim) e o nome da pessoa falecida, além de uma mensagem de condolência geral. Ao menos $18 \%$ dos comentários traziam alguma referência ao contexto da morte e $6 \%$ foram feitos por pessoas que claramente não tinham nenhum contato com o falecido. Os pesquisadores supõem então que esses "santuários espontâneos" têm a função de tornar público o luto que ocorreria de forma privada (Klastrup, 2014). Poderíamos também 
inferir a função reparadora, a partir de uma concepção de eficácia simbólica, de tornar pública uma resposta para uma morte trágica, em direção ao morto e à comunidade.

A morte de pessoas públicas sempre se transforma em um acontecimento social e suscita a circulação de afetos de maneira intensa.

Katie et. al. (2017) chamam tal categoria de luto - quando ocorre entre um alguém que não era conhecido de outro - de luto parasocial, uma derivação da ideia de relação parasocial, uma relação que aconteceria apenas para um dos envolvidos, mas sentida de forma similar às relações íntimas que conjugam ao menos dois. Uma paisagem bem característica é quando grupos de fans se reúnem para sofrer coletivamente a morte de um líder ou celebridade que provavelmente não lhes conhecia.

Em sua pesquisa, Katie et al. (2017) identificam um conflito entre "normas" adotadas por diferentes pessoas em relação a como se comportar diante do falecimento de alguém, sobretudo ao se deparar com ondas de reação a partir da morte de alguma celebridade. Dá o exemplo, após anunciada a morte de um ator que participou de Harry Potter, de reações de alguns usuários diante da tristeza escancarada através de comentários de outros: "Okay people!!! I understand that Alan Rickman was a pretty good actor (even if he usually played grumpy types) .... but PLEASE- stop with the whole "Boo Hoo, I'm sooo sad!" shit. You never met him, you didn't know him.... move on to being sad about something that matters [...] (Comment \#204, Rickman)".

Ou seja, a ideia de conceber um luto parasocial incomoda outros usuários que provavelmente não entendem como alguém pode ser tão tocado pelo falecimento de alguém que não conhecem pessoalmente.

No Brasil, muitos também se incomodaram profundamente com grandes manifestações de tristeza após o falecimento de pessoas públicas, como foi no caso do assassinato da vereadora do Rio de Janeiro, Marielle Franco.

Historicamente, essas reações já foram muito mais extensas e muito mais intensamente sentidas, por exemplo a partir da morte de Carlos VII, que o povo,

"[...] fica fora de si tão logo vê o féretro: todos os dignitários da corte 'vestidos de luto fechado, que dava muita pena de ver; e a dor e a grande tristeza que se viam neles pela morte de seu senhor fizeram toda a cidade prantear e lamentar' [...] de tão triste, um dos rapazes não comia ou bebia havia quatro dias, comentava o povo enternecido" (Huizinga, 2010, p. 18). 
Porém, ao menos a partir do Século XVI, já “[...] não existe mais lugar em torno do morto para as grandes e longas deplorações de antigamente; ninguém mais declama em voz forte as saudades e os elogios, como outrora" (Ariès, 2014, p. 217), transformando as antigas lamentações em leitura do ofício dos mortos, passagem para os especialistas da morte.

Além das manifestações em perfis públicos de luto, tristeza, saudades, fora dos WRS's também existe espaço para declinar a limitação geográfica para lidar com o rito fúnebre através da tecnologia. Walter et. al. (2016) destacam que além de questões que concernem a uma espécie de atualização das práticas de memorização e luto que já existem offline para as plataformas online, vários serviços oferecidos para transmitir os funerais e até cremações via streaming já são disponibilizadas por empresas que trabalham na área. Dessa forma, parentes que não conseguiriam chegar a tempo, podem assistir um funeral em tempo real através de câmeras instaladas no local do ritual. Também podem encomendar flores, cartas ou orações especificas à distância.

Algumas possibilidades tecnológicas vão além: o aplicativo With Me, da empresa sul-coreana ELROIS, permite que os usuários façam selfies e conversem com avatares de seus amigos ou familiares mortos, a partir da pretensão de "apaziguar um coração ferido"*4. Além disso, aplicativos não especificamente criados para isso são cada vez mais usados para realizar um “duplo digital" de alguém que faleceu: o Replika ${ }^{5}$, por exemplo, é um aplicativo desenhado com uma interface bem facilitada que permite o usuário interagir com seu duplo e o quanto mais o usuário interage, mais o aplicativo aprende seus padrões de linguagem e suas probabilidades de resposta em determinada conversa. Sendo assim, o mesmo pode ser usado para reproduzir conversas de alguém que já faleceu e simular respostas que o morto daria. $\mathrm{Na}$ realidade, qualquer programa de respostas automáticas pode ser adaptado a esse uso, inclusive adaptados à simples aplicativos como o Facebook Messenger e o WhatsApp.

Em 2017, no X Simpósio da Associação Brasileira de Pesquisadores em Cibercultura (ABCIBER), apresentei um bot adaptando um aplicativo de respostas automáticas para o WhatsApp. Na ocasião, passei meu número para os outros pesquisadores para que interagissem com o bot. No Painel Temático que reunia pesquisadores do eixo sobre inteligência artificial, hibridização homem-dispositivo, trans-humanismo, wearables, os que interagiam com o aplicativo, no qual coloquei informações, não ao acaso, do personagem Quincas Berro D'água,

\footnotetext{
${ }^{4}$ Cf. http://www.elrois.com/eng/sub/ray_3d.php

${ }^{5} \mathrm{Cf}$. https://replika.ai/
} 
protagonista da obra A Morte e a Morte de Quincas Berro d'Água, de Jorge Amado, relataram certo estranhamento e um efeito surpresa quando respondidos de forma automática.

A escolha poderia ser facilmente substituída por um familiar já falecido, o aplicativo preenchido com suas informações, inclusive ultimas localizações por GPS, e os familiares poderiam assim conversar com essa "réplica" do falecido. Tal questão foi explorada pela série inglesa Black Mirror, sucesso no mundo inteiro por suscitar questões que atravessam as relações humanas a partir da tecnologia, sobretudo as que tencionam temas sensíveis como política e saúde. O episódio que abre sua segunda temporada, chamado Be Right Back (2011), envolve uma protagonista que ao perder seu namorado em um acidente, contrata uma empresa que oferece exatamente este serviço: primeiro, um aplicativo que simula suas mensagens a partir do seu histórico de interações; depois, quando resolve assinar o plano premium, um autômato que reproduz fisionomia, corpo e todos os comportamentos adotados outrora pelo falecido. A narrativa encontra um ponto de ruptura quando a protagonista passa a perceber a falta de equívocos, de erros, uma espécie de biunivocidade da linguagem que gera estranhamento e decepção. O episódio é feliz em evidenciar a diferença da linguagem de máquina e da linguagem humana a partir da falta da equivocação. $O$ autômato entra em confusão quando demandado a discutir com ela, à não corresponder suas demandas de forma "automática".

Jed Brubaker et. al. (2013, p. 25), ao fazerem uma extensa pesquisa que se propôs a pensar sobre a forma como as pessoas já lidam e os fenômenos que se estabelecem a partir dos perfis de falecidos que continuam nos WRS's, sugere o termo tumba interativa digital para se referir à esses casos. Quer dizer, como o morto não está apto a moderar o conteúdo entorno de sua representação, os sobreviventes encontram em tal espaço uma forma de descrever suas narrativas sobre o falecido; o que transforma tais espaços, tais perfis, em ambientes propícios à construção de novas narrativas sobre o falecido. Os autores dão o exemplo de uma entrevistada que descreve o quanto ficou impressionada ao perceber como a atividade do mergulho era importante para seu primo e como ela não tinha ideia disso antes de se deparar com a narrativa de seus pares no perfil do falecido.

Assim, de acordo com Jed Brubaker et al. (2013, p. 25), tais narrativas podem envolver tanto questões que comungam entre os sobreviventes quanto estranhamentos e pontos de tensões entre os mesmos: a diversidade dos grupos sociais que interagem com o morto evidência diferenças nas narrativas. Os autores (Id. p. 29) concebem a ideia de que os usuários, nos WRS's, são atravessados por encontros diferentes com a ideia de morte: constatam a partir de publicações que alguém faleceu e também se deparam com perfis de falecidos que continuam 
na programação automática do próprio Facebook: esses “encontros inesperados” geram reações diversas nos usuários. Essas novas formas com que os usuários se deparam com a morte e procedem a partir dela aconteceriam a partir de três categorias de expansão: temporal, espacial e social.

A expansão temporal teria a ver com o próprio funcionamento dos WRS's: a flexibilidade de um meio assíncrono, particularmente sobre as notificações da morte, e o entrelaçamento da morte às experiências cotidianas, faz com que parte dos usuários continuem se engajando com perfis de falecidos, compartilhando memórias, novidades e falando sobre o morto. Como resultado, seria visto um entrelaçamento entre morte e o luto de forma contínua no cotidiano, diferente do conjunto temporal que se refere às práticas rituais dos funerais e memórias tradicionais. Inclusive a pesquisa encontra uma tristeza bem particular em relação aos usuários que sabem da morte de alguém querido de forma tardia (Brubaker et al., 2013, p. 31).

A expansão espacial se refere às supressões das barreiras físicas, o que fica bem evidente no exemplo retro referido de um funeral ao vivo transmitido através da internet. Já a expansão social, teria a ver com a disseminação das informações e o colapso do contexto na auto representação online. Ou seja, tal disseminação pode unificar grupos sociais que eram separados previamente e conectá-los a partir da morte de um usuário, colocando-os frente à outras narrativas sobre uma mesma pessoa, podendo gerar diferentes efeitos: relacionamentos casuais, narrativas a partir de diferentes contextos e uma nova narrativa a partir desses encontros. A expansão social inclui o falecido no espaço social dos WRS's, e estabelece uma nuance bem delicada pois em algum nível, existiria uma continuidade desse falecido no campo social dos sobreviventes, produzindo efeitos de forma contínua (Brubaker et al, 2013, p. 28).

Porém, antes de adotarmos o conceito de tumbas interativas digitais, devemos esmiuçar a relação entre as práticas fúnebres e ritos que se referem à lida do ser humano com a morte independentemente dos WRS's e então demarcar as possíveis diferenças. Além disso, ao trabalharmos também com a ideia do sujeito no campo digital, é importante percorrer o arenoso campo da identidade: poderíamos pensar em uma identidade digital?

Já é tão difícil demarcar o conceito de identidade fora do campo digital, poderíamos ao menos delimitar então essa intersecção de maneira precisa? A ideia de uma identidade digital também figura entre uma preocupação dos pesquisadores do campo, o que implica em discutir as incongruências que concernem ao campo da identidade, mas também em pensar como o conceito de ciberespaço influencia e é influenciado por essa tópica. O capítulo seguinte tratará 
dessa questão em um movimento que intitulei "das identidades aos modos de subjetivações digitais".

\subsection{Das identidades aos modos de subjetivações digitais}

Identidades Digitais se referem ao conjunto de informações que o usuário deposita no ciberespaço ou ao próprio jogo dialético impresso no manejo que o usuário realiza ali, aonde ele pode se representar? Tal identidade independe do usuário ou simplesmente se esvai assim que o usuário corporalmente falece? Seriam seus traços e marcas no ciberespaço identidades digitais?

Brubaker (2015), se contrapõe à alguns autores que sustentam a separação entre o conceito de identidade online de uma identidade digital, como se a identidade online se referisse à uma representação direta do sujeito e a identidade digital ao data, o conjunto de informações que excluiria o próprio sujeito. Endosso essa não separação e penso que a questão da identidade é um terreno arenoso, sendo digital, online ou não. É fácil cair em um discurso do self ou do ego, como se se tratasse, para usar uma alusão de Lacan (1979), de um homúnculo que dirigisse um carro, uma unidade bem delimitada que pudesse dar conta de um pensar pelo sujeito.

Brubaker (2015, p.5) dá uma luz interessante ao se propor a circunscrever de que forma poderíamos trabalhar com uma ideia de identidade digital:

"Identidades digitais ocupam o lugar das pessoas por elas representadas; identidades digitais são o subproduto de performances sociais que foram alocadas em um sistema técnico, de tal forma que o sistema pode re-presentar essas performances".

Ou seja, enquanto derivação das performances sociais, a noção de identidade digital estaria atrelada à uma "captura" da representação performática das pessoas que participam desse sistema técnico. Ainda assim, tal definição poderia ser considerada audaciosa, afinal, a partir do momento em que o autor considera a possibilidade de que o sistema represente essas performances, tal representação simplesmente se descolaria do jogo dialético que depende da interação do sujeito no sistema.

Sua sugestão implica e infere na possibilidade de uma identidade que já se reproduz na própria cadeia do sistema. Sendo assim, se tomássemos tal proposição como precisa, depois do 
falecimento corpóreo de alguém, poderíamos lidar com sua identidade através de suas redes sociais, renovada a cada nova interação, como uma espécie de entidade digital.

Porém, mesmo com a representação que o sistema pode fazer dessas performances, em algum momento o sujeito que interage com tais perfis se daria conta de um certo automatismo, a repetição própria de algo que não produziria mais alguma mensagem nova. Então, mais que uma identidade digital, o sujeito que interage com tais perfis, interage com um arquivo, mas mais interativo que a tumba tradicional.

A Profa. do Massachusetts Institute of Technology (MIT) Sherry Turkle, oferece uma interessante aproximação entre a noção lacaniana de um eu ilusório, desalojado, com a ideia da Internet como um elemento propício para concebermos a questão de como a identidade poderia encarnar algo da ordem de uma multiplicidade. A autora (Turkle, 1997) pensa que, nessa aproximação, a leitura lacaniana oferece uma alternativa às escolas das relações objetais (inglesa) e à primeira geração freudiana, que teriam abandonado a perspectiva original e radical de Freud, de uma visão descentrada do eu, e de forma análoga o percurso da internet também oferece um exercício possível de uma performance, de diferentes "personalidades" que o sujeito poderia encarnar ao interagir na rede, o que ela denomina multiplicidade.

Turkle (1997) conta casos em que entrevistadas suas evidenciam uma relação com a internet na qual os usuários imprimiam, ou melhor, exerciam personalidades diferentes, alternando entre umas e outras. Dois dos casos: uma mulher que tinha relações com um amante virtual e está afoita com o que pode encontrar ao vivo: “[...] Só espero, na presença dele, conseguir meterme na pele do meu eu online durante algum tempo" (Turkle, 1997, p. 264) e uma outra mulher que oscilava entre três papeis que forjara para si mesma em um website de comunicação, Internet Relay Chat (IRC).

Para Turkle (1997, p. 265), apesar de adotarmos uma ideia de identidade que sempre envolveu diversas "máscaras" ou papéis, o que se transforma a partir do advindo do computador, no que ela denomina "era pós-moderna", é a facilidade da transição entre tais papéis, pois,

“[...] no passado, esta rápida alternância entre diferentes identidades não era uma experiência facilmente acessível. Outrora, é claro, as pessoas [...] assumiam diferentes papéis e máscaras sociais, mas, na maioria dos casos, o seu envolvimento vitalício com uma determinada família e comunidade mantinha esta alternância sob um controlo bastante rígido e apertado" (id. p. 265)

Dessa forma, Turkle (id.) aponta como a internet converge com uma ideia de um eu dotado de várias "identidades alternativas", assim como um laboratório social em que as performances se 
encontram. Ao menos em termos de intensidade, o que transforma essa alternância de identidades em algo mais acessível e facilitado. O que a autora interroga é sobretudo como poderíamos pensar as relações a partir dessa ideia. Se, afinal, mediadas pela internet, tratamos de e com pessoas "inteiras", até expansões do eu ou algo descolado propriamente do que chamaríamos de um eu. Porém, Turkle (id.) ainda sustenta uma diferença entre "identidades virtuais" e uma certa coerência da "vida real". Talvez essa seja justamente uma antinomia que devamos colocar em xeque, sobretudo na Psicologia.

O que Pierre Lévy desconstrói tanto em seu livro Cibercultura (2010) quanto em $O$ que é o virtual? (2011) é justamente o par oposto entre virtual e real, largamente propagado a partir das narrativas que trabalham com temas da internet. Virtual não seria o par oposto de real. O par oposto de virtual, se pensarmos no plano filosófico, é o atual, é em relação a uma razão temporal que podemos nos referir. Virtual é potência, faculdade, o que pode vir a ser. O virtual, para Levy (2011), tem a ver com a atualização, em uma permanente dialética entre o par virtual/atual.

Uma semente de melancia implicaria uma teleologia própria e uma suposição de melancia. E é assim, virtual como o dinheiro, o mercado, a palavra. Para Lévy (2010, p. 51), “o virtual é uma fonte indefinida de atualizações". Porém, para o autor (2011, p. 16), o virtual não se trata de uma sinonímia de contingencial, pois se desfaz a oposição entre o que produz e é produzido pois:

\footnotetext{
"Por um lado, a entidade carrega e produz suas virtualidades: um acontecimento, por exemplo, reorganiza uma problemática anterior e é suscetível de receber interpretações variadas. Por outro lado, o virtual constitui a entidade: as virtualidades inerentes a um ser, sua problemática, o nó de tensões, de coerções e de projetos que o animam, as questões que o movem, são uma parte essencial de sua determinação".
}

Porém, lidamos com a ideia de virtual no senso comum como algo que concerne, em um amplo espectro, ao "mundo da internet", como se tratasse de um outro mundo. Turkle (1997) se interessa justamente pela performance dos usuários na internet e seus desdobramentos para pensarmos questões identitárias. A autora se refere aos MUD’s (Multi-User Dungeos), um tipo de rede social muito em voga na época em que escreveu tal obra. Os MUD's nada mais são que jogos de RPG (role-playing game), os famosos jogos de interpretações de papéis nos quais os jogadores simplesmente adotam o papel de personagem e percorrem uma narrativa, construindo e interagindo com ela e com outros usuários.

Os jogadores de MUD's trabalham a partir da mesma base de dados, mas podem interagir com outros utilizadores, objetos, “cidades”. Mas, ao invés de lidar com paisagens gráficas ultra 
elaboradas, esses usuários percorrem um "jogo de palavras", no qual a experiência é toda através de construções descritivas: “[...] Construir nos MUD’s é algo de híbrido entre a programação e a ficção literária” (Id. p. 268).

Turkle (1997) se refere aos MUD's para apontar o que considera um fenômeno próprio do eu na contemporaneidade: apesar de se fragmentar em várias facetas, os usuários confidenciam para a autora que se sentem mais "livres" e mais à vontade para "aparecer" nessas narrativas ficcionais. Alguns exemplos são interessantes, como um usuário de vinte e dois anos que constrói personagens violentos: “[...] acho preferível violar mulheres nos MUD’s, onde não faço mal a ninguém” e uma secretária de vinte e seis anos que diz “[...] mesmo que nos MUD’s eu me desmultiplique em vários eus, sinto-me mais ‘eu própria' nessas ocasiões” (id. p. 273).

Nesse sentido, poderíamos inferir que a mediação digital serviria para que os usuários realizassem algo da ordem do desejo em espaço fantasístico, que remeteria à fantasia mesma, mas seria precipitado. Tal questão se desdobra na direção de refletirmos se se trata, para adotar uma antinomia de Turkle, de por um lado um "desempenho de papéis”, ou do exercício mesmo de "vidas paralelas".

A interrogação que se coloca é se a mediação digital se revelaria um entrave, um dispositivo forçoso, algo que cristalizasse demasiadamente uma imagem de um eu "coerente", indivisível, de um indivíduo indiviso, reflexo de uma concepção de mundo contemporânea e que provavelmente se desmonta em algum momento, nem que seja no momento mori - e aqui, o tema desse trabalho se faz tão significativo - ou então se se trata de algo que opera no campo dos possíveis, de um princípio de prazer, que afloraria e despontaria na realização do irrealizável, do fantasístico que se desprende do corpo e do sensível: um homem que pode performar como mulher num joguete preciso e que pendula entre papéis/performances ou outro que realiza seu desejo de violentar sem que para isso machuque fisicamente alguém. Nos dois casos, porém, parece que a ideia de um sujeito que evita riscos, sobretudo os dois riscos mais fundamentais, a morte e a sexualidade e seus desencontros, poderia encontrar no ciberespaço uma espécie de promessa que se reforça continuamente e almeja tanto a imortalidade quanto controles sobre os desencontros próprios do sexual.

Para Nusselder (2009, p.11), poderíamos encarar o ciberespaço como uma "alucinação consensual": assim como nos exemplos anteriores, aquilo que não poderíamos realizar na realidade, seria realizado via tela da fantasia. O ponto chave da tese de Nusselder (2009) é que a tela do computador funcionaria no ciberespaço como um espaço psicológico, como uma tela 
da fantasia. Assim como o mundo entendido como um suporte não apareceria para nós no ciberespaço, sem uma interface que possa exercer a mediação; então, essa interface, para o autor, teria um status similar à concepção de fantasia na teoria lacaniana. O autor (2009, p. 29) recorre à concepção lacaniana de objeto pequeno a (objeto causa do desejo) para explicar nossa relação com a tela:

"[...] A psicoterapia online, e as relações online em geral, poderiam ser desinteressantes - e consequentemente se esgotar - se nós (inconscientemente) não postulássemos 'alguma coisa' nas impressões que recebemos do outro na tela (Lacan converte essa "coisa" em sua teoria como o objeto a: objeto causa do desejo e que colocar o desejo em movimento; a fantasia decora, desenha, esse objeto). O outro é mais do que sua imagem na tela. Toda a coisa sexual na Internet iria parar sem o seu suporte fantasmático. Pois, se simplesmente o medíssemos contra a 'realidade face-a-face, verdadeira', perceberíamos imediatamente que não é real e deixaríamos de surfar. Os mundos virtuais online também são uma expressão da fantasia, mas, como muitos usuários atestam, estão longe de ser apenas uma ilusão imaginária: os usuários os amam e 'vivem neles' - com todas as ambiguidades associadas a essa frase."

A concepção de Nusselder (id. ibid.) é muito interessante porque emparelha os dispositivos digitais e sobretudo a tela, a interface, com a noção de fantasia, sem recorrer às categorias que concebem o ciberespaço como algo irreal, ou como uma contraposição da realidade. Porém, incorre em um pequeno equivoco quando se refere, mesmo entre aspas, à uma realidade facea-face, assim "verdadeira". Acredito que o que faria com que deixássemos de surfar não seria uma medição comparativa com a "realidade face-a-face"; mas sim, se a interface fosse desprendida da ideia de um outro e do Outro que lá habita: essa impressão que o usuário tem é uma condição para que ele possa encarar o que está na tela e seus traços que lhe captam como aquilo que remonta ao objeto, e, consequentemente, aquela coisa que lhe causa desejo. Aliás, Miller (2008, p. 404) observa precisamente que a ideia lacaniana de Grande Outro evacua a dimensão de um ser de carne, e ressalta justamente seu "caráter maquinal”, simbólico; porém, representado por um corpo sexuado, então humano.

Se esse não for o suposto, um suposto que exige que o usuário deposite na tela tal garantia: a de que haja um outro lá, em uma relação dialética do desejo e do reconhecimento, um outro sujeito, além daquilo que remonta a um espaço simbólico; afora propriamente do exercício de um "eu”, o usuário, mais que desinteressado, seria atravessado por uma estranha sensação, assim como quando brincávamos com o brinquedo Tamagotchi:

“tratamos como ente um não ente virtual: agimos 'como se' (acreditássemos que) houvesse, por detrás da tela, um Self real, um animal reagindo a nossos 
sinais, embora saibamos bem que não há nada nem ninguém 'atrás', apenas circuitos digitais" (Zizek, 2013, p. 111).

Tal problemática coloca em questão algumas das principais interrogações que o ciberespaço tenciona: em última instância, se poderíamos conceber uma réplica como um ente, ontológico, se de fato nos comunicamos e sobretudo a emersão da consciência em uma "realidade" compartilhada. Talvez, se adotássemos a premissa de que qualquer consciência seja virtual e de que quando nos referimos à identidade, nos referimos à uma noção de um eu que não seria substância, tampouco centrado, tanto para os referidos "desconstrucionistas" mas também para linhas distintas da Psicologia (vide a ideia de centro de gravidade narrativa ou a consciência como rede de narrativas, de Daniel Dennett) (Zizek, 2013, p. 89), poderíamos ao menos parcialmente, avançar no exame de uma possível identidade digital.

Turkle (1997) descreve as comunidades virtuais do outro lado da tela como espaços nos quais a identidade poderia ser "reconstruída" a partir de uma cultura da simulação. Esse é um recorte interessante quando usamos para pensar em variações como cibersexo e a questão de gênero, além da violência nas redes. A autora conta como usuários descrevem e se definem costumeiramente a partir do gênero oposto para realizar "sexo virtual", que geralmente consiste na descrição de uma cena ou em simulações gráficas do próprio ato.

No Brasil, salas de bate-papo destinadas à tais modalidades, "fantasias escritas" continuam em voga com muito sucesso. Já a questão da violência, que poderia ser concebida como simples desdobramento de tal cultura da simulação, pode produzir efeitos políticos e práticos irreversíveis. Incontáveis casos de "linchamento virtual" transbordaram para fora das telas e tiveram como consequência perseguições e mortes: em um dos mais trágicos, uma mulher fora perseguida na cidade do Guarujá (São Paulo), acusada por um boato nas redes de realizar magia negra com crianças ${ }^{6}$.

Uma hipótese para pensarmos casos assim se ampara na concepção de uma certa dimensão asséptica das redes. Os usuários teriam a impressão que, de forma análoga ao game, um ato poderia simplesmente ser apagado, em um espaço no qual violência apareceria apenas como simulacro. Seus efeitos, excluindo a noção prática de consequência ao outro, seriam apenas "virtuais", como joguetes que não atravessam os corpos ou qualquer dimensão sensível.

\footnotetext{
${ }^{6}$ Cf. http://g1.globo.com/sp/santos-regiao/noticia/2014/05/mulher-espancada-apos-boatos-em-rede-socialmorre-em-guaruja-sp.html
} 
A diferença da escrita na tela e a escrita no rolo, no papel, em qualquer suporte material, é que o usuário tem essa impressão de que o apagamento não deixa manchas, marcas, que simplesmente faz desaparecer aquilo que estava escrito. Goldin (2001) faz uma reflexão sobre a relação disso com a violência ao citar um trabalho de Michelle Reverbel no qual crianças expressam desejos violentos em relação às outras quando inseridas em oficinas de literatura. A dimensão asséptica disso seria a implicação própria de uma "cultura de simulação" ou de uma gamificação da vida cotidiana. Em contrapartida, sabemos que isso se trata apenas de uma impressão, pois tudo o que se opera na telinha deixa rastros e registros em diferentes níveis e passíveis de resgate técnico.

Essa referência à tela como analogia de nossa relação perceptiva fora usada, não ao acaso, por Freud (2011), em sua Nota sobre o "Bloco Mágico", de 1925, o wunderblock. Nesse ensaio curioso, Freud (2011) faz referência ao bloquinho que contém uma fina camada de celuloide transparente, e que é utilizada para escrita através da pressão que um estilete faz entre o verso do papel encerado contra a tabuinha de cera. Para poder apagar, o usuário deve apenas levantar ou "balançar" o bloquinho, desfazendo assim o contato do papel encerado com a tabuinha de cera nos lugares pressionados que formavam a escrita. Apagado, o aparelhinho está pronto para novas anotações.

Freud (id. p. 271) faz uma analogia clara de tal aparelho com a "estrutura do aparelho psíquico perceptual". Apesar do apagamento, ao levantar a folha de cobertura inteira, percebemos que o traço duradouro permanece na tabuinha de cera, sobretudo se usada uma iluminação adequada. Esses traços são marcas indeléveis e é por isso que Freud (op. Cit.) escolhe tal modelo para se referir ao aparelho psíquico perceptivo. Nas telas do ciberespaço todo acontecimento é também registrado, e apesar da impressão constante da possibilidade de apagamento, o sujeito deixa registros e marcas ao navegar; e, ademais, produz efeitos em outros sujeitos implicados na dinâmica. Mas, há sujeito lá aonde insiste seu registro independendo do corpo? Afinal, na dialética do sujeito no ciberespaço, resta alguma identidade quando o corpo e consequentemente a autopercepção se esvaem?

Lacan, tanto no Seminário 1 (1979) quanto no Seminário 2 (2010) oferece uma alternativa interessante para tal questão, que perpassa a ideia da implicação do sujeito na constituição dos aparelhos, que são atravessados em sua cadeia de comunicação pelo registro simbólico utilizado por aqueles que a pensaram e construíram - os seres humanos - o que embasa a ideia de que a expressão "aparelhos subjetivos" não se refere à uma contradição em termos, afinal, o aparelho é “(...) inteiramente construído com a ajuda de um x e de um y, que habitam o domínio em que 
vive o sujeito, quer dizer, o da linguagem" (Lacan, 1979, p. 106). O desdobramento de tal ideia retoma a questão do cogito, afinal, se se trata de um sujeito descentrado, que "está enfiado num jogo de símbolos, num mundo simbólico [...] é com esse mesmo jogo, com este mesmo mundo, que a máquina é construída" (Lacan, 2010, p. 69).

Portanto, quando nos referimos à noção de identidade digital, mais que sobreposições de imagens e identificações com as quais o sujeito se apresenta no ciberespaço, também devemos pensar no mundo simbólico que a constitui e a orienta. Sem que caiamos em uma "humanização" adiantada da máquina - um sonho caro aos precursores da ideia de Inteligência Artificial - mas possamos pensar que algo próprio do ser humano, o registro simbólico, a linguagem, está estampado e possibilita o funcionamento da máquina. Essa também foi uma questão levantada de forma análoga pelo criador do conceito de Cibernética, Norbert Wiener (1968). A tese de Wiener era de que:

"A sociedade só pode ser compreendida através de um estudo das mensagens e das facilidades de comunicação de que disponha; e de que, no futuro desenvolvimento dessas mensagens e facilidades de comunicação, as mensagens entre o homem e as máquinas, entre as máquinas e o homem, e entre a máquina e a máquina, estão destinadas a desempenhar papel cada vez mais importante" (Id. p. 16).

Além da linguagem, para o sujeito que navega no universo online, a função da adoção de uma “identidade" pode ter diversas facetas. Seria fácil recairmos para uma leitura moral e definir o ciberespaço como um espaço puramente imaginário (que se refere aqui a imagem), no qual as identidades, espécies de sobreposições de identificações imaginárias, permaneceriam cristalizadas, fixadas na tela como ideais editáveis, em que o sujeito se apresenta para o outro sujeito - ou outro avatar de um sujeito - da forma que entende mais pareada possível com seu ideal, a partir de um punhado de traços eleitos. Precisamos levar em conta um certo empuxo ao narcisismo nesse sentido, mas essa é uma das direções de tal processo, que, como assiná-la Lerude (2017, p. 204), “parece excluído, [...], ou, antes, reduzido à sua própria imagem”.

Porém, o recurso da identidade digital enquanto função é tão ambivalente quanto a própria noção de identidade. Turkle (1997, p. 388) faz uma definição muito interessante nesse sentido:

"Quando as pessoas adotam uma identidade online, penetram num território prenhe de significados e implicações. Algumas experimentam uma sensação desconfortável de fragmentação, outras uma sensação de alivio. Algumas pressentem as possibilidades de autodescoberta, ou até autotransformação, que se the oferecem".

O que o campo dos possíveis aberto e contingenciado pelo ciberespaço escancara é justamente a impossibilidade de pensar o sujeito de uma forma unitária, indivisível, de um indivíduo, 
pretendendo eliminar as divisões e, portanto, multiplicidades de cada um. Se tal espaço pode servir para ancorar uma imagem rígida e projeções identificatórias sobrepostas, em uma preponderância da circulação de imagens, é também no ciberespaço que a possibilidade de performar certos desejos, por vezes impossibilitados pela realidade, pode encontrar vazão.

O campo digital coloca em evidência a questão do sujeito e seus limites, inclusive de um limite que seria último e que tanto nos interessa a partir do tema: a finitude. Essa é uma questão importante para o tema da morte pois um dos anseios humanos mais estridentes seria justamente o desejo da imortalidade e suas implicações tecnológicas. O que confere um certo protagonismo no recorte é justamente a diferença entre máquinas e humanos e os tabus que envolveriam coloca-los em pé de igualdade.

O sonho de imortalidade tal qual a ideia de equivaler homens e máquinas foram essenciais para a história do desenvolvimento tecnológico e influenciaram em muito os teóricos do conceito de Cibernética e suas derivações.

Wiener (1968), em sua obra Cibernética e Sociedade, aponta sua inspiração em eleger o conceito de "Cibernética", derivado da palavra grega Kubernetes: timoneiro, piloto, governador. Se, por um lado, sua preocupação girava em torno de pensar a sociedade por meio de um movimento que tencionasse a comunicação ao máximo e examinasse uma espécie de tendência à entropia,

"[...] a minha tese é a de que o funcionamento físico do indivíduo vivo e o de algumas das máquinas de comunicação mais recentes são exatamente paralelos no esforço análogo de dominar a entropia através da realimentação" (Wiener, 1968, p. 26),

por outro, a analogia entre o funcionamento de humanos e máquinas - assim como o fizeram Freud, citado por Wiener, e Lacan, que o dedica várias das aulas de seu segundo seminário, para Wiener, a questão é necessária especificamente para pensarmos no papel que tal leitura deveria exercer no contexto social, enquanto "respostas orgânicas da própria sociedade".

Wiener (id. p. 13), leitor de Freud, faz uma aproximação entre Gibbs e Freud no que tange ao elemento do acaso:

"[...] no reconhecer um elemento fundamental de acaso na textura do próprio universo, esses homens estão próximos um do outro, e próximos da tradição de Santo Agostinho". 
E é a partir da concepção de um princípio de prazer freudiano que pudesse ser radicalmente levada à cabo, que nos depararíamos então com um paradoxo, o do repouso absoluto, por isso sempre um mais além do princípio do prazer, e sobretudo da satisfação.

Porém, em Deus Golem e Cia. (Wiener, 1971, p. 53-54), o autor vai além e propõe a eliminação de uma antinomia conceitual que apresentasse humanos e máquinas enquanto polos distintos:

"não há procedência em afirmar categoricamente que os processos de reprodução em seres vivos e em máquinas, nada tem em comum [...] a ideia de que a suposta criação divina de homens e animais, a procriação de seres vivos e a possível reprodução de maquinas sejam partes de uma só ordem de fenômeno é, de fato, perturbadora [...] se pareceu ofensiva ao nosso orgulho a comparação do homem com o macaco, nós já a superamos. Comparar o homem à máquina parece anda mais ofensivo. Cada ideia, em sua época, está associada à repulsa que esteve associada, no passado, ao pecado da feitiçaria"

Se tal ideia corresponde a uma resposta à crítica que trata, ainda hoje, tecnologia e feitiçaria enquanto similares, e sobretudo estabelece uma premissa de comparação entre o homem e a máquina, ao menos serve para entendermos a citação de Turkle que atribui, dentro de um campo de estudos da psicologia e psicanálise, uma visão de sujeito dividido, não individuo, de uma consciência não absolutamente única, a um tempo histórico atrelado às transformações tecnológicas e vice-versa.

Dessa forma, a nossa visão de homem e de sujeito se transforma a partir também das transformações tecnológicas. A discussão sobre a experiência do homem no ciberespaço, não obstante, retoma discussões complexas sobre conceitos centrais da filosofia, do corpo sensível à ontologia. Zizek aponta que se há uma lição derradeira do ciberespaço, é que este "ensina" algo próprio da condição humana: “[...] não apenas perdemos nosso corpo material imediato, mas aprendemos que tal corpo nunca existiu - nossa auto experiência corpórea sempre-já foi aquela de um ente imaginário construído" (Zizek, 2013, p. 118). Nesse sentido, o ciberespaço talvez sustente, de uma forma um pouco mais explicita, o "corpo freudiano - erotizado, sustentado, pela libido, organizado em torno de zonas erógenas - não-animalístico" (id. ibid), mas fundamentalmente preso, atravessado e afetado pela linguagem, em uma organização que adquire uma noção de sujeito e de homem radicalmente atrelada ao simbólico, que extravasa inclusive nossas noções de tempo cronológico e, portanto, de finitude, instrumento e de morte. Lacan trabalha com tal perspectiva em seu escrito Situação da psicanálise em 1956, remetendo o leitor à uma ética própria da psicanálise que se oriente a partir de um inconsciente encarado sob a via de uma exterioridade do simbólico: 
"um psicanalista deve assegura-se nessa evidência de que o homem, desde antes de seu nascimento e para-além da morte, está preso na cadeia simbólica, a qual fundou a linhagem antes que nela se bordasse a história [...] Dessa heteronomia do simbólico, nenhuma pré-história nos permite apagar o corte. Muito pelo contrário, tudo o que nela nos entrega só faz aprofunda-lo mais: instrumentos cuja forma serial volta-nos mais para o ritual de sua fabricação do que para os usos a que eles tenham sido adaptados; - amontoamentos que não mostram outra coisa senão o simbólico antecipatório da entrada do simbólico no mundo; - sepulturas que, para-além de qualquer motivação que possamos imaginar para elas, são edifícios que a natureza não conhece. [...] Essa exterioridade do simbólico em relação ao homem é a noção mesma do inconsciente. E Freud provou constantemente que se atinha a ela como sendo o próprio princípio de sua experiência"

Porém, tais movimentos não encerram a escolha de atrelar, especificamente e precisamente a partir do ciberespaço, para além da operação simbólica que implica e é implicada pelo sujeito, a ideia de identidade e de digital.

Como cooptei a ideia de identidade digital dos teóricos que trabalham com os websites de redes sociais, sobretudo Jed Brubaker e Sherry Turkle, passarei, a partir das problemáticas conceituais retro referidas, a adotar a partir daqui a expressão subjetivações digitais, para precisar a tradição teórica tratada e evidenciar os efeitos subjetivos e de subjetivação próprios do campo digital. Enquanto tradição, a palavra identidade se refere costumeiramente ao idêntico: às identificações construídas, que nunca se fecham - afinal, identifica-se, mas o fado é sempre outro, um idemoutro - sobreposições identificatórias que concernem às construções imaginárias do sujeito.

O idem, sinal de repetição. Para a psicanálise, em um certo sentido:

"a identidade aparece também como construção imaginária de uma representação social que mascara a presença do Outro no si mesmo e avaliza sua pertinência no mundo humano. Desta forma, a identidade surge como sintoma, defesa contra angústia de não poder saber sobre si, a não ser a partir da imagem, tomada em si mesma, como metáfora congelada em um único sentido, sem, no entanto, perder sua propriedade de ser mensagem" (Debieux, 1997).

Apesar de conservar também essa função, como vimos nos exemplos de Turkle (1997), a adoção de determinadas "identidades digitais" é tão polivalente quanto qualquer espectro do campo dos possíveis que envolve modos de subjetivações vigentes e, portanto, determinados também pelos meios de engajamento simbólicos de sua época. Então, para estender tal significação, ou ao menos amplifica-la para abrigarmos o efeito de sujeito, de subjetivação, sugiro uma passagem de identidades digitais para modos de subjetivações digitais.

\subsection{O porquê do virtual e do digital}


Escolhi usar o termo digital no trabalho como adjetivo: identidade digital, tumbas interativas digitais, legado digital, subjetivações digitais e arriscaria na proposição de cunhar o conceito de morte digital. Outros termos muito utilizados por quem pretende se arriscar em oferecer uma leitura do campo digital a partir da Psicologia é virtual, ciberespacial, cibernético, entre outros. No capítulo precedente, tateei a ideia de virtual em Pierre Levy (2010) e as problemáticas que se referem ao seu uso. No tocante às polissemias, Levy (2010) aponta suas diferentes significações: em uma definição do senso comum, se refere ao falso, irreal ou ilusório. No sentido filosófico, enquanto potência. No cálculo computacional, um "universo de possíveis calculáveis a partir de um modelo digital e de entradas fornecidas por um usuário" (id. p. 77).

Outra definição interessante para pensar no tema da pesquisa: o mundo virtual enquanto sentido do dispositivo informacional e enquanto sentido tecnológico estrito, se refere respectivamente à mensagem como "espaço de interação por proximidade dentro do qual o explorador pode controlar diretamente um representante de si mesmo" e enquanto "ilusão de interação sensóriomotora com um modelo computacional” (Levy, 2010, p. 76). Poderíamos arriscar, a partir dos últimos possíveis dos websites de redes sociais como Snapchat, que já não existiria distinção entre tais categorias.

Se, no primeiro caso, enquanto dispositivo informacional, o conceito se refere à construções de mundos virtuais, de narrativas que se engajam com narrativas de outros usuários, de forma semelhante à descrita por Turkle (1997); no segundo caso, enquanto sentido tecnológico estrito, o conceito se refere também aos gadgets, que permitem uma espécie de hibridização no corpo, ou uma espécie de "escriturização técnica do corpo" - como os datagloves, datasuits, ou mais recentemente, o google glass: os smartphones atuais levam à cabo a eliminação da diferença entre tais categorias descritas por Levy.

Mas, para Levy (2011, p. 77), a ideia de virtual se estende à uma eventualidade aberta: da palavra (ainda não dita) aos rituais, religiões, leis, ordenações que correspondem à “dispositivos para virtualizar os relacionamentos fundados sobre as relações de forças, as pulsões, os instintos ou desejos imediatos”. Porém, autores como Philippe Queau (1993), atrelam a questão da virtualização com uma noção própria de tempo, que enquanto função, assim como o que chama de imagens-síntese, nos afastaria do real: que considera interrogação máxima do contemporâneo e colocada em voga a partir do virtual. 
Essa é uma das problemáticas ao trabalhar com a noção de virtual, a de que diversos autores incorrem no par oposto entre virtual e real, como se tratasse puramente de uma representação direta de um "mundo das coisas", a partir de uma noção histórica que problematiza o contemporâneo vislumbrando uma causalidade entre as técnicas e seus efeitos de "virtualização do mundo", e assim lidássemos com um real sondável, descritivo e acessado igualmente entre nossos pares, um ideal de biunivocidade entre linguagem/referente, palavra/coisa. Weissberg (1993, p. 119) também apresenta esse par oposto para então colocá-lo em xeque:

“[...] o virtual no lugar do real corresponde a uma dicotomia visivelmente exportada das categorias de representação (imagem no lugar do objeto, maquinas no lugar do homem etc.) A decodificação de sua trajetória em termos de evicção ou de predominância do virtual sobre o real é sem dúvida portadora de uma interrogação ética salutar. Por outro lado, não é certo que essa trajetória seja a única em processo. Múltiplas experiências, pesquisas, aplicações tendem a constituir uma outra cenografia em que os atores (real/virtual, objeto/imagem, conhecimento humano/programa inteligente) ocupam posições inéditas".

Incorremos aí as voltas do problema tão caro à psicanálise e à psicologia do sujeito e suas relações com o objeto. Enquanto dimensão do real, o virtual pode ser encarado a partir de dois paradigmas apresentados por Weissberg (Id. Ibid.): “[...] virtual e real são duas faces de uma mesma questão. O virtual não substitui o real, ele ajuda a lhe dar sentido" e "[...] torna-se uma de suas formas de percepção num misto em que as duas entidades são simultaneamente requisitadas".

Essa acepção do virtual já se aproxima da adotada - e cooptada da física ótica - por Lacan em sua teorização sobre o estádio do espelho: o corpo passa a ser encarado, circunscrito virtualmente, enquanto unidade, a partir de uma mirada em seu reflexo, do olhar que se direciona à imagem especular.

Diante de tais claudicações, armadilhas conceituais, creio que adotar o digital enquanto campo preciso para trabalhar com temas que concernem aos websites de redes sociais, à mediação através da internet e em geral as transformações tecnológicas que nos atravessam e são por nós atravessadas, que são efeito das criação e também agentes nessa dialética entre o sujeito e seu maquinário simbólico, é o mais razoável.

Se operar uma digitalização consiste em traduzir uma informação em números (Levy, 2010), a concepção de binarização nos interessa pois se uma informação pode ser explicitada ou medida, ela pode ser traduzida dessa forma. No digital, sem perda de informação - muito diferente dos sons e imagens analógicos - “[...] a informação digital usa apenas dois valores, nitidamente 
diferenciados, o que torna a reconstituição da informação danificada incomparavelmente mais simples" (Id, p. 53).

0 ou 1: o princípio da não contradição materializado, codificado como números, processando de forma rápida e precisa em grande escala. Se a virtualização é inerente à própria história do homem, a digitalização da informação - traduzida para 0 ou 1 - circunscreve um momento característico e, portanto, descreve de uma forma mais interessante os modos de subjetivação que concernem ao contemporâneo.

Circunscrita em um continuum, para Levy (2010, p. 51), “[...] a comunicação continua, com o digital, um movimento de virtualização iniciado há muito tempo, pelas técnicas mais antigas, como a escrita, a gravação de som e imagem, o rádio, a televisão e o telefone”. Porém, a informação digital, qualificada de virtual, só pode ser acessada através da sua atualização. Ou seja, através de algum modo de exibição.

Para Levy (Id. Ibid.), apesar da comunicação assíncrona, independente do espaço, recíproca, habitar a humanidade há muito tempo, o que diferencia radicalmente o ciberespaço é a possibilidade de os seres humanos acessarem uma memória comum em qualquer tempo e descolados das contingências geográficas. Inteiramente novo e muito interessante para pensarmos na questão da morte.

Dessa forma, me indago se não poderíamos conceber o arquivo de um morto que navegava na internet como uma espécie de hipertexto: passível de edição, sem uma narrativa que condicione o leitor à iniciar e terminar a partir de determinado ponto fixo e portanto operado a partir daquele que o acessa e o edita, que o inscreve em outra narrativa e assim reescreve o corpo textual. Criador torna-se criatura e vice-versa, até a dinâmica da antinomia ficar completamente deslocada, ocupando cada posição de uma forma diferente. Assim como o hipertexto, estaríamos lidando com outra matriz de textos potenciais ${ }^{7}$ ?

Contudo, várias narrativas sobre os mais diversos personagens históricos/religiosos poderiam ser interpretados a partir dessa perspectiva. Tal concepção, que Levy (id. p. 60) define na Web como a de hiperdocumentos de "escrita-leitura coletiva", transforma as narrativas sobre os mortos e até as escritas pelos mortos em registros documentais mais móveis, voláteis, que se transformam quando editadas e comentadas por quaisquer navegadores. Tal dinâmica é análoga à metáfora de Jorge Luis Borges (2001), que encara a biblioteca como um espaço no qual os

\footnotetext{
${ }^{7}$ Expressão usada por Pierre Levy (Id. Ibid.)
} 
mortos, procurados pelos vivos, são atualizados na medida em que são lidos, procurados: “[...] penso que em toda biblioteca há espíritos. E esses são os espíritos dos mortos que só despertam quando o leitor os busca". Uma bela dinâmica na qual poderíamos pensar o virtual sendo atualizado.

É também a partir dessa intersecção, da relação com a morte enquanto virtualização necessária, que Levy (2011, p. 125) se aproxima de uma possível "virtualização original": a forma como o cadáver de um morto é tratada é conditio sine qua non para a humanidade enquanto tal, operador fundamental. O morto depois do rito é um "operador de socialização", e se a "carne em decomposição não é virtualizada como corpo do morto, isso é sinal certo da desintegração de um grupo, de sua desumanização".

Não ao acaso, percebemos que nesse sentido, do rito enquanto processo de virtualização primeiro ou ao menos enquanto função simbólica e regulatória, em períodos de barbárie e violência, testemunhamos o desaparecimento dos cadáveres ou a redução dos mesmos à pedaços de carne. Thomas (1996, p. 9) estabelece um paradigma no qual o próprio homem poderia ser definido como um animal que prática ritos funerários, uma prática simbólica necessária para reestruturar uma comunidade machucada e poder demarcar a separação entre os vivos e os mortos.

Pensemos então sobre as atitudes perante a morte nos websites de redes sociais justamente para refletir também sobre como as pessoas se sentem e experimentam o luto a partir do momento em que o rito envolve um arquivo que continua circulando entre os vivos, ao menos teoricamente mais interativo. No próximo capitulo, falarei um pouco da morte enquanto conceito e como seria possível trabalhar com tal ideia, de significado sempre fugidio. 


\section{Pensar a morte}

Como falar, escrever, pensar sobre a morte? Morrer enquanto verbo, quando e se conjugado em primeira pessoa no passado ou no presente transforma o enunciado em um paradoxo lógico. Eu morri, eu morro: um problema que arrepia os lógicos e um paradoxo que poderia se desdobrar em digressões infindáveis. Aquele que experimenta a morte não pode nos falar sobre. Enquanto falamos sobre ela ainda não se fez presente, afinal, ainda falamos. O jogo de presença e ausência em sua mais proeminente anunciação. Se é passado ou presente, impossível enunciar à não ser por uma condicional: passar do pé da letra à metáfora. Eu morro... de amor. E sobre o futuro? Só podemos pensa-la a partir da experiência de um outro, deduzi-la, supô-la. É sempre uma experiência que concerne à linguagem e sobretudo vicária. Se alguém se foi, bem provavelmente seremos brindados com o mesmo destino. Um provável que impera como fado, suposto fado. Mas se trata de uma suposição de tamanha importância, que poderíamos arriscar afirmar que delineia toda a experiência de quem está vivo, e, não obstante, talvez o império da técnica - que em sua positividade contínua almeja desabrigar a ideia de pausa e de fim - tente responder justamente ao receio da morte.

Em sua famosa Carta a Meneceu, na qual Epicuro oferece uma espécie de cartilha para uma vida mais feliz, programa para uma moral que pudesse dar conta de ensinar ao interlocutor como encarar a vida, um dos temas centrais é como lidar com a ideia de morte:

\footnotetext{
"Acostuma-te a ideia de que a morte para nós não é nada, visto que todo bem e todo mal residem nas sensações. A consciência clara de que a morte não significa nada para nós proporciona a fruição da vida efêmera, sem querer acrescentar-lhe tempo infinito e eliminando o desejo de imortalidade" (Epicuro, 2002, p. 27).
}

Tal proposição moral implica conceber a ideia da morte como um conceito sem significação, mas o filósofo bordeia determinada significação: ela estaria fora do campo das sensações e da vida efêmera, além de concernir ao tempo não-infinito, cronológico. Além disso, Epicuro (Id. Ibid.) se propõe a resolver a questão dialética entre presença e ausência a partir de uma espécie de interdição do pensamento: "a morte, não significa nada para nós, justamente porque, quando estamos vivos, é a morte que não está presente; ao contrário, quando a morte está presente, nós é que não estamos".

Essa condição de uma vida feliz, que dependeria do desejo de imortalidade barrado, mas também de um apagamento forçado de tudo que remete à morte no campo da linguagem e dos 
costumes, é uma atitude visível na contemporaneidade. É isso que Ariès aponta quando se refere ao medo atual até de "ousarmos dizer-lhe o nome" (Ariès, 2014), contrastando com as atitudes dos antigos.

Freud (2010a, p. 234), na contramão de Epicuro, sugere, em seu "Considerações atuais sobre a guerra e a morte" transformar a máxima Si vis pacem, para bellum em Si vis vitam para mortem. É uma proposição precisa: para aguentar a vida, é preciso se preparar-se para a morte.

Apesar de tratada pelo senso comum como a única certeza, é diretamente insondável. Examinamos escritos, restos, livros, memórias em registro: aquilo em que dela se deixa escapar. Falar diretamente sobre a morte como um referente escancarado, uma entidade isolada, um conceito fechado ou uma significação sobre o qual podemos nos referir com precisão compartilhada é um equívoco. A relação do ser humano e suas atitudes perante a morte se transformam radicalmente com o caminhar da história. Também se transformam os ritos, passagens e a forma como os vivos interagem com os mortos, inclusive algumas culturas não estabelecem uma linha muito concreta de separação, e isso gera implicações aos vivos.

Afinal, o que a anuncia? Tratar o cadáver como um referente indelével seria ignorar a história: gerações inteiras de médicos se interessaram pela morte aparente e o tema povoou a imaginação de todos no século XVII e XVIII:

“[...] Em 1876, certo médico escrevia que um 'pânico universal' tinha então se apoderado dos espíritos, diante da ideia de ser enterrado vivo, de despertar no fundo do tumulo. Ele não exagerava." (Ariès, 2014, p. 527).

Tal medo pode ser encontrado em testamentos que datam a partir de 1662, reunindo conjuntos de condições para que o corpo daquele que viesse a falecer pudesse ser enterrado. Em 1740, o medo da inumação ainda em vida gerou uma verdadeira literatura especializada, que "retomou os dados antigos, os milagres de cadáveres, os gritos ouvidos nos túmulos e os cadáveres devoradores" (Ariès, 2014, p. 529), para reinterpretá-los a partir da ideia de que os ritos da sepultura fossem, de fato, precauções para evitar os enterros precipitados. Discussão que mobilizou ao menos três gerações de médicos, a dos séculos XVI e XVII, a do século XVII e no final do século XIX.

Precisamente, o que os médicos do final do século XIX não podiam aceitar, é que houvesse um estado misto entre o vivo e o morto. Precisava ser um ou outro. A morte "[...] não passava de uma palavra equívoca da linguagem natural que era preciso abolir da linguagem unívoca da ciência, para designar a parada da máquina, simples negatividade” (Ariès, 2014, p. 538). 
Em tempos de uma validação do princípio da não contradição através do discurso médico e científico, abrigar um termo tão polissêmico, fugidio, equivocante, era - e talvez ainda o seja impensável. Era preciso demarcá-la bem precisamente.

Porém, para os médicos dos séculos XVI, XVII e XVIII, o tempo da morte era um estado misto, de vida e morte. Para eles, apenas na decomposição se encontraria a morte absoluta, podendo retardar-se pelo embalsamento (Id. Ibid.).

Até hoje, essa é uma questão para a medicina: o critério de Harvard, de 1968, que estabeleceu a morte encefálica como critério de morte, levanta várias controversas, que incidem desde a prática para caracterizar o silêncio cerebral até as questões éticas que concernem à doação e transplante de órgãos (Santos, 1997).

De acordo com França (2015, p. 910), autor referência em Medicina Legal, ao discorrer sobre a morte encefálica e a necessidade de uma precisão conceitual do momento da morte, define:

\begin{abstract}
"A morte, como elemento definidor do fim da pessoa, não pode ser explicada pela parada ou falência de um único órgão, por mais hierarquizado e indispensável que seja. É na extinção do complexo pessoal, representado por um conjunto, que não era constituído só de estruturas e funções, mas de uma representação inteira. O que morre é o conjunto que se associava para a integração de uma personalidade [...]"
\end{abstract}

No Brasil, os parâmetros para aferir uma morte encefálica se encontram na Resolução CFM número 1.480. Questões para apontar um signo exato da morte esbarram em variáveis como em casos de "estados vegetativos persistentes" e doentes terminais. França (Id. p. 919), considera que "[...] o momento da morte não pode ser objeto de diagnóstico porque ele não é evidente nem avaliado" e que a definição da morte "depende das evidências de sinais claros que indiquem a privação da atividade vital como um todo".

O autor (Id. Ibid.) também discorre sobre a dificuldade do problema da consciência e propriamente questões éticas que concernem à possibilidade de manter as funções vitais de um corpo com privação irreversível da consciência, ainda uma pessoa. Ou, em outros casos, através da tecnologia, o que ele critica veementemente: "[...] manter tecnologicamente um simulacro de vida, prolongar um sofrimento ou insistir no medicalismo obstinado da medicina fútil”.

Essa curta referência da Medicina Legal nos serve apenas para apontar como o terreno da definição conceitual da morte é opaco em diversos saberes - como ela se confunde e se aproxima de questões propriamente filosóficas e psicológicas - da consciência, autoconsciência, representação, auto representação, eu, objeto, coisa, etc... 
Freud também se depara com a dificuldade de conceituar a morte, sobretudo a ideia da própria morte. Sobre a dos outros, manteríamos uma atitude ambivalente que culminaria no tabu, “oposição entre a dor consciente e a satisfação inconsciente com a morte havida" (Freud, 2013, p. 59) e todos os desdobramentos para recriminar um desejo inconsciente que habitava o sujeito antes do acontecimento. Mas as atitudes dos vivos em relação aos mortos também se transformariam com a história, e Freud (2013) sugere um caimento da ambivalência e se refere à máxima latina para descrever seu tempo - de mortuis nil nisi bene - dos mortos não se fala, a não ser bem.

Também no subcapitulo Nossa atitude perante e morte, do texto Considerações atuais sobre a guerra e a morte (Freud, 2010a), encontramos preciosas observações sobre o conceito próprio da morte. Para Freud (2010a), como para Ariès (2014), a atitude geral diante da morte é praticamente "reduzi-la ao silêncio" (Id. p. 230). E é nesse texto que Freud se refere a ideia da própria morte como inacessível ao inconsciente:

“[...] na escola psicanalítica pudemos arriscar a afirmação de que no fundo ninguém acredita na própria morte; ou, o que vem a significar o mesmo, que no inconsciente cada um de nós está convencido de sua imortalidade" (Id. Ibid.).

Em contrapartida, sobre a morte dos outros, se evitaria falar; e somente as crianças ignorariam tal restrição (Id. Ibid.). Freud (2010a) também tenciona a ideia de que preferimos encará-la como algo fortuito ao invés de necessário, apontando sempre uma relação de causalidade, seja doença, acidente, idade avançada. Lembremo-nos que o necessário na lógica não é o contingente nem o impossível, é aquela proposição que não poderia deixar de acontecer.

A ideia de Freud (Id. Ibid.) nesse texto é uma verdadeira crítica da forma como lidamos com a morte, e um apontamento de como a guerra faria com que essa atitude mudasse, pois a lida passaria à ser mais estridente: “[...]As pessoas morrem de fato, e não mais isoladamente, mas em grande número, às vezes dezenas de milhares num só dia. Isso já não é acaso.” (Id. p. 233).

Em contrapartida, destaca essa atitude, a dizer, de ignorá-la, reduzi-la ao inefável, como algo empobrecedor da própria vida, como algo que seria um impeditivo para realizar tarefas interessantes e ousadas:

"Não ousamos considerar muitas empresas que são perigosas, mas necessárias, como as tentativas de voar, as expedições em terras distantes, os experimentos com sustâncias explosivas. Paralisa-nos o pensamento de quem haverá de substituir o filho para a mãe, o marido para a mulher, o pai para os filhos, caso aconteça um desastre. A tendência a excluir a morte dos cálculos da vida traz consigo muitas outras renuncias e exclusões. No entanto, o lema 
da Liga Hanseática dizia: 'navigare necesse est, vivere non necesse!' (Navegar é preciso, viver não é preciso.) (p. 232)"

Freud (2010a) realiza um percurso que se refere a Totem e Tabu para voltar a tratar da ambivalência em relação a morte dos amados, que ao mesmo tempo amados e estranhos, incutiam no homem primevo algo da ordem do conflito.

Apesar de não conceber a ideia da possibilidade da própria morte, o homem primevo teria lidado com tais ambivalências quando se deparava com a morte de algum de seus amados. É aí que, ao invés da especulação filosófica, o que nasceu foi justamente a Psicologia: “[...] o homem primevo teria triunfado junto ao corpo do inimigo abatido, mas sem ver razão para quebrar a cabeça com os enigmas da morte” (Id. p. 237), e do conflito entre a morte de pessoas amadas e ao mesmo tempo estranhas e odiadas, dessa ambivalência teria nascido a própria Psicologia.

E desse conflito, entre consciência de culpa pela satisfação que se entrelaçava com o luto, surgiam os espíritos recém-criados, para que se pudesse lidar com a morte de alguém amado, e então se tornavam demônios e suscitavam medo nos vivos.

Claude Lévi-Strauss (2008) chega à uma conclusão quase análoga ao fazer uma análise através da antropologia estrutural para desvelar o ritual do suplicio do papai noel, ocasião na qual os mortos, através da figura das crianças, visitariam os vivos para que os vivos lhe ofereçam presentes:

“[...] Não surpreende, pois, que o Natal e o Ano Novo (seu duplo) sejam festas de presentes: a festa dos mortos é, na essência, a festa dos outros, visto que o fato de ser outro é a primeira imagem aproximada que podemos construir a respeito da morte" (Id. p. 43).

E é a partir do rito que se poderia, de alguma forma, aplacar a agressividade dos mortos em relação aos vivos (Freud, 2013) (Vincent, 1996) (Lévi-Strauss, 2008). É sobre uma atitude perante à morte que Freud se refere, mas também de uma relação entre os mortos e os vivos que se empobreceria com o fato de os vivos não suportarem pensar na ideia da própria morte:

“[...] Nosso inconsciente é tão inacessível à ideia da própria morte, tão ávido por matar estranhos, tão dividido (ambivalente) em relação à pessoa amada como o homem das primeiras eras. Mas como nos afastamos desse estado primevo em nossa atitude cultural-convencional diante da morte!" (Freud, 2010a, p. 245).

E não sem efeito, absolutamente. Para Lévi-Strauss (2008, p. 44):

“[...] outra atitude em relação à morte continua a avançar entre nossos contemporâneos: talvez feita não de modo tradicional de espirito e fantasmas, e sim do medo de tudo que a morte representa, em si mesma e para a vida, em termos de empobrecimento, aridez e privação". 
Tais referências claudicam ora para tratar da própria morte enquanto conceito, ora para tratar das nossas atitudes perante a morte, incluindo aí sempre uma psicologia própria do luto, que antes da psicologia, foi pensada pela filosofia.

\section{1: Teorias do conhecimento sobre a morte}

Algumas posições em relação a ideia da morte são preponderantes naquilo que poderíamos denominar como teorias do conhecimento sobre a mesma: a primeira, uma atitude de esvaziála e ignorá-la, endossada por Epicuro e rastreada no contemporâneo por Ariès. A segunda, que desde Max Scheler, passando por Heidegger até Freud, que mesmo entendendo que o sujeito talvez não tenha uma apreensão da própria morte, prescreve uma atitude de encará-la, se preparar para tal. A terceira, em Paul Ricoeur, uma crítica férrea em direção à esta, sobretudo em Heidegger, que o mesmo considera que se trataria de uma antecipação de si como "já cadáver" (Ricoeur, 2012).

A noção da morte enquanto uma constante, inerente ao ser, permeia tanto Max Scheler (2017) quanto Heidegger (2005). De acordo com Scheler (2017, p. 28), enquanto elemento não empírico, habitaria a própria experiência humana:

“A morte não é, portanto, um mero elemento empírico estável da nossa experiência, mas pertence à essência da experiencia de cada vida (e também à nossa própria experiencia) o facto de estar dirigida para a morte. A morte pertence à forma e à estrutura na qual, somente, cada vida nos é dada, e nossa tal como a dos outros [...] Ela não é m quadro que é ocasionalmente acrescentado à imagem de processos psíquicos ou fisiológicos isolados, mas um quadro que pertence a essa própria imagem e sem a qual ela não seria a imagem de uma vida [...]".

Scheler (Id. Ibid.) crê que uma espécie de certeza intuitiva da morte nos acompanha e pauta nossos comportamentos em vida; e que ao invés de um evento cortante, a mesma deve ser entendida como algo que não pode ser desatrelado da própria vida, que se dirige desde antes para a morte. Já em Heidegger (2005), ao problematizar a questão da morte e da ideia da morte pensada, forja em seu ser-para-a-morte uma proposta de solução, de uma possibilidade ontológica, que pudesse antecipar tal pre-sença e abrigar esse poder-ser ôntico que lhe concerne. Tal é a descrição de Heidegger (2005, p. 50):

"Pode-se resumir a caracterização do ser que, existencialmente, se projeta para a morte em sentido próprio, da seguinte forma: a antecipação desentranha para a pre-sença a perdição no próprio-impessoal e [...] a coloca na possibilidade 
de ser ela própria: mas isso na LIBERDADE PARA A MORTE que, apaixonada, factual, certa de si mesma e desembaraçada das ilusões do impessoal, se angustia".

Heidegger (2005) parece se preocupar em forjar um conceito de ser-para-a-morte que dê conta da morte própria, não exatamente pensada, mas enquanto possibilidade ontológica, desatrelada das "ilusões do impessoal", que se tratariam precisamente de como as pessoas pensam a morte no cotidiano: o "falatório do impessoal: algum dia se morre mas por ora ainda não", um "escape encobridor" (Id. p. 40), esse "mas" que esvaziaria a noção da própria morte.

Os dois autores incorrem em uma questão curiosa: ao tentar dar conta do conceito de morte, sugerem um ser atravessado pela mesma, mesmo antes de morrer, o que dá um sentido preciso ao conceito de antecipação. Paul Ricoeur critica o que considera uma hierarquia "entre a autenticidade heroica da angustia do ser incessantemente confrontado com a morte e a banalização de um morrer inautêntico que foge da morte" (Abel, 2012), que se trata da lógica própria da filosofia de Heidegger.

Em um belíssimo texto, Vivo até a morte, Ricoeur (2012, p. 9), já com 83 anos, anuncia sua batalha "contra essa imagem do morto de amanhã" e refuta de forma visceral a ideia da morte como uma agonia antecipada, de uma posição pretensamente corajosa, heroica, em relação a uma atitude perante a morte que significaria um "meu já-estar-morto de amanhã". O que ele contrapõe a isso é um desejo de ser, de existir, um vivo até a morte enquanto ética, ao invés de um ser-para-a-morte, em um movimento que ao rejeitar a antecipação, essa ode à angústia, se converteria ao júbilo de um "vivo-ainda".

Em minha síntese: se Scheler concebe um homem dirigido para a morte, portanto também pelamorte e Heidegger um ser-para-a-morte, e, portanto, também pela-morte, Ricoeur defende um "vivo-ainda" ou um até-a-morte que nem se propõe à antecipa-la nem à refuta-la, mas à aceitála de forma jubilosa.

A contrapartida de Ricoeur implica também em uma ética em relação ao moribundo, de um olhar, que ao invés de prever, de antecipar, de uma direção para a morte, se desloca para o vivo e se propõe a acompanha-lo “até lá...”. Sua proposição é radical para uma Psicologia do cuidado em relação ao moribundo ou de cuidados paliativos: o olhar daquele que cuida, de acordo com Ricoeur, não deveria ser de complacência antecipatória de uma morte que é certa para todos, mas da vida radical que ainda impera até lá. Afinal, se preparar para o que?

Em Lacan (2016, p. 360) também encontramos essa ideia de que a questão intolerável da morte não concerne à nossa própria, mas a do outro: “a dimensão propriamente intolerável que se 
oferece à experiencia humana não é a experiencia da nossa própria morte, que ninguém tem, mas a da morte de um outro, quando ele é para nós um ser essencial”.

É difícil pensarmos em um conceito de morte desatrelado da ideia de uma atitude perante a mesma e ao se deparar com a leitura que diferentes autores oferecem para a questão, recaímos em certa "Psicologia do Luto", mas também em um campo de intersecção entre Psicologia e Morte. Por isso, no próximo capitulo me debruçarei sobre a ideia de uma "Psicologia para a Morte"8 e seus desdobramentos teóricos.

\subsection{Uma Psicologia da Morte ou para a Morte.}

Uma grande parte dos interesses da Psicologia enquanto ciência foram direcionados aos estudos do luto, da perda, dos efeitos da morte nos que ficam. Em contrapartida, alguns autores direcionaram esforços para compreender os efeitos da morte enquanto uma ideia aterrorizante e seus desdobramentos para pensarmos em temas que interessam à Psicologia.

Uma das obras pioneiras no assunto, que se propôs a organizar temas a partir dessa intersecção, fora dos autores Robert Kastenbaum e Ruth Aisenberg (1983): respectivamente uma autoridade no campo da suicidologia e editor da respeitada Omega - The Journal of Death and Dying e sua coautora, pesquisadora do Hospital Infantil de Boston.

Os autores direcionaram seu interesse para diversos fatores, que incluem a percepção infantil da morte, as variáveis culturais, a "personificação da morte”, proposições e anseios éticos em relação a morte e questões que se referem ao processo de luto. A leitura, por exemplo, da personificação da morte, como uma "estratégia básica do homem para estabelecer uma relação entre seu estado íntimo e o universo" (Kastenbaum e Aisenberg, 1983, p. 375), aparece como tema comum aos pesquisadores da área. Se, por um lado, podem enveredar para uma concepção que é interpretada como uma tentativa de significar algo que os autores consideram um "estímulo singularmente vazio", um contínuo "estímulo ausente", por outro, podemos interpretar como uma via para lidar propriamente com o medo da morte.

\footnotetext{
${ }^{8}$ Sublinho aqui meu estranhamento em relação ao uso da expressão "Psicologia da Morte", mas que poderia se desdobrar ao uso de diversas expressões que concernem à psicologia: algo como se o evento fosse dotado de uma psicologia própria.
} 
Os autores (Id. p. 188) constatam que as pessoas lidam melhor com o que denominam "morte natural", que se refere aos casos dos quais aqueles que falecem se tratam de idosos. A questão cronológica serviria então como uma malha de conforto e consolo, mas que revelaria um outro aspecto: o de que entenderíamos a morte como algo não-natural, uma espécie de acidente relegado apenas aos velhos.

O delineamento da questão desboca nesse tema caro aos pesquisadores da área, o medo da morte, espécie de terreno compartilhado em uma Psicologia da Morte.

Por exemplo, a teoria que se desenvolveu, derivada dos estudos em Antropologia Cultural e Psicologia, de Ernest Becker, denominada Teoria do Gerenciamento do Terror (TMT, Terror Management Theory), que de acordo com Paiva (2016, p. 13), "propõe que a consciência da mortalidade, de que só a espécie humana é capaz, é a fonte do desenvolvimento psíquico, que permite gerenciar essa consciência e controlar a ansiedade existencial dela decorrente".

Antes, um detalhe sobre sua inspiração: de fato, a obra magna de Becker (1993), A negação da morte, gerou grande alvoroço sobretudo nos Estados Unidos. Vencedora do Prêmio Pulitzer de não-ficção em 1974, Becker (1993) situa o medo da morte e sua negação como a grande questão da humanidade, o "verdadeiro desespero da condição humana" (Id. p. 261). Enquanto universal, esse desespero seria decerto um impossibilitador para uma vida razoavelmente feliz. Sua crítica irascível, a de que uma psicologia que prometesse uma via de "cura" através do conhecimento de si mesmo, estaria se propondo a ofertar duas promessas: a do "industrialismo comercial", que "prometia ao homem ocidental um paraíso na Terra, descrito de forma muito detalhada pelo Mito de Hollywood" e o "paraíso celestial, prometido pelo mito cristão" (Id. p. 264). Nesse contínuo impossível de sustentar, partindo do pressuposto de que se tratava de mais uma “ideologia de imortalidade”, a Psicologia se tornaria então mais um sistema de crenças.

De acordo com o autor (Id. Ibid.), enquanto sistema de crenças, a Psicologia só poderia encarar tal questão através de três possíveis:

"o psicólogo ser um gênio criativo e usar a Psicologia como o veículo da imortalidade para si mesmo - como fizeram Freud e outros [...] usar a linguagem e os conceitos da Psicologia em grande parte da vida [...] e a terceira [...] é pegar a psicoterapia e aprofundá-la com associações religiosas e metafisicas, para que ela se torne realmente um sistema de crença religiosa com uma certa extensão e profundidade".

Vislumbrando a posição do psicólogo, psicanalista, mestre e guru religioso como análogas, Becker (Id. Ibid.) sustentava que, como uma conscientização de algum problema não o eliminava - o que é escancarado radicalmente pela mortalidade - ele defendia uma Psicologia 
que oferecesse uma significação própria e a "criação de novos heroísmos que sejam basicamente uma questão de crença e vontade, de dedicação à uma visão" (Id. Ibid.).

Apesar das críticas confusas, que indiferenciam pontos centrais entre Psicologia e Psicanálise amparando-se em uma interpretação bem singular de Otto Rank - e que sugerem que a Psicologia exerça uma espécie de doutrina do sentido unívoco e que ofereça, de forma análoga às religiões, respostas sobre questões existenciais das mais diversas, seu trabalho fora importante para localizar a questão do medo da morte e elevar seu estatuto à central para pensarmos no terror que a inevitabilidade da morte evoca.

Autores que se inspiraram em tal receio, desenvolveram sobretudo na década de 1970, a Teoria do Gerenciamento do Terror. De acordo com Paiva (2016, p. 13), a TMT (Terror Management Theroy) trata-se de uma teoria psicossocial, pois "trata principalmente dos modos como a humanidade consegue continuar vivendo com o controle, ou o gerenciamento, do medo de morrer". Se, por um lado, os esforços teóricos e empíricos se depararam com efeitos negativos - violência, guerra, preconceito - derivados de um funcionamento que estabelece a própria visão de mundo enquanto ideal e a de grupos diferentes enquanto ameaça; por outro, se depararam com alguns efeitos positivos que suscitam atitudes e comportamentos que envolvem cuidados de si mesmo e dos outros. Ou seja, o medo de morrer poderia produzir também efeitos positivos nas relações sociais.

Tal proposição é a constatação de uma pesquisa elaborada por Vail et al. (2012): de que a consciência da própria morte pode também motivar as pessoas a cuidar mais da própria saúde e priorizar atividades de desenvolvimento pessoal, crenças positivas, construir relações de suporte, entre outros. Os autores encaram a consciência da morte como uma espécie de catalisadora, um ponto central de um modelo heurístico, que pode funcionar como "ativadora" para evocar questões de cuidado pessoal e de grupo, abrigando envolvimentos positivos com a comunidade e também uma certa "abertura para o novo".

Assim, podemos considerar que os efeitos que se dão a partir da "consciência da morte", ou da finitude, ou a lida com o medo da morte, são contingentes, ou seja, negativos ou positivos (e creio que em uma análise aprofundada, negativos $e$ positivos, ambivalentes).

Essa é uma noção muito interessante para pensarmos em uma questão levantada por Elisabeth Kubler-Ross, em sua obra importante para a tanatologia e uma Psicologia da Morte: Sobre a Morte e o Morrer (1987). Nela, Kluber Ross estabelece métodos para tratar e realizar entrevistas com pacientes que justamente se deparam com a ideia de morte em condições terminais. As 
entrevistas forneceram elementos para delinear um verdadeiro "programa" de sentimentos que se espera que os pacientes terminais tenham após a constatação de seu fado. Em estágios: negação e isolamento, raiva, barganha, depressão, aceitação.

Um elemento comum entre todos: a esperança contínua de que algum tratamento novo ou algum acaso o tiraria daquela situação (Id.). É um trabalho interessante, sobretudo por reunir entrevistas valiosas com pacientes em condição de moribundos. Porém, é possível que entrevistas abertas que evoquem o horizonte da morte em pessoas sadias realizassem resultados análogos, mas isso precisaria ser atestado por um trabalho equivalente.

A autora também oferece uma valiosa reflexão àqueles que trabalham diretamente com a morte, a "consciência de morte" do terapeuta que acompanha pacientes terminais:

“[...] ser terapeuta de um paciente que agoniza é nos conscientizarmos da singularidade de cada indivíduo [...] é uma tomada de consciência de nossa finitude, de nosso limitado período de vida" (Id. p. 178).

Penso, a partir dos caminhos expostos, que uma Psicologia da Morte ou para a Morte se trate de um exame psicossocial que se direcione a pensar em atitudes perante a morte e seus desdobramentos clínicos e psicossociais. Se partirmos da premissa de que a ideia de morte seja algo acessível, constante, que paira sobre os seres humanos de forma irascível, tal percurso suscita questões existenciais, mas também de articulações possíveis: interrogações sobre as relações entre morte e possíveis discursos que apresentam enfrentamentos ao medo: da religião à tecnologia. Paiva (2016) percebe uma “contribuição superior da religião à superação do terror da morte", com "efeitos positivos [...] apontados pela TMT como mais poderosos do que os que resultam de outros valores culturais".

Nesses termos, creio que a tecnologia e sobretudo os esforços que se orientem na direção de pretender eternizar a vida através da tecnologia, preocupação evidente dos teóricos da I.A. (Inteligência Artificial), se torna análogo ao esforço religioso.

É a partir da reflexão de Zizek (2013) - de que a razão ciberespacial, em sua lida com o corpo, contém uma dimensão radicalmente gnóstica - que encontro um paralelo com quaisquer sistemas de crenças que produzam sentidos para refrear o terror em relação a morte e a finitude. Portanto,

"[...] se a definição mais concisa do gnosticismo é, precisamente, a de que ele é uma espécie de materialismo espiritualizado: seu tema não é diretamente a realidade mais elevada, puramente nocional, mas a realidade corporal 'mais elevada', uma protorrealidade de sombrios fantasmas e entes "não-mortos"" (id. p. 118). 
Ou seja, algo que não dependeria do corpo, pois este está fadado as condições naturais do fim, do adoecimento, da morte. Nesse sentido, poderíamos inferir que existe uma direção do ciberespaço enquanto alternativa ao medo da morte. Os corpos escriturais e imaginários que ocupam tal lugar seriam etéreos, habitantes ideais de um mundo puramente das ideias.

Essa é também a leitura de Luc Ferry (2011) sobre os modos que os gregos adotavam para lidar com o medo da morte: o primeiro, produzir uma descendência. Ter filhos reservaria um lugar aos homens na eternidade, identificação em imagem e semelhança; o segundo, o heroísmo, nas figuras heroicas que competem diretamente com a Natureza e que, como Aquiles, figuram na escrita, aquilo que se salva do efêmero; o terceiro, a filosofia - aquele que, reconhecendo-se em um lugar no cosmos e se vislumbrando enquanto parte da eternidade - poderia viver uma espécie própria de "misticismo cosmológico" que aplacaria o sentimento de finitude. Três dimensões insuficientes, mas que operariam para aplacar o medo da morte.

Essa leitura de Luc Ferry (2011) é valiosa pois também trata de colocar o medo da morte enquanto problema fundamental para pensarmos na assunção e organização de sistemas próprios de crenças, seja a partir de algum discurso religioso, filosófico, biológico ou que concerne a construções como o gnosticismo (talvez na intersecção das outras). Creio que poderíamos pensar, a partir de uma Psicologia da Morte, em exercer uma leitura do discurso da tecnologia, sobretudo em uma organização que poderíamos chamar de "razão ciberespacial", enquanto parte destes entrelaçamentos, dessas dialéticas que operam o medo da morte a partir de diferentes perspectivas que o aplacariam. Talvez, enquanto estratégias de refreamento, de forma análoga às admitidas pela TMT (Terror Management Theory). Porém, se trata apenas de uma hipótese e o objetivo deste trabalho não é derivar para essa direção.

Essa escolha se dá justamente pelo motivo de que quando pensamos na Psicologia da Morte, os trabalhos costumam se direcionar a esse medo, suas estratégias de refreamento, seus desdobramentos; em públicos costumeiramente específicos, como participantes de determinadas religiões, doentes terminais; ou em espaços determinados, como hospitais e casas de saúde.

Já o usuário que se depara com a ideia de morte nos websites de redes sociais (WRS's), além de talvez se interrogar sobre tais temas, sobre finitude, anseios, medos; os efeitos de tal

\footnotetext{
${ }^{9}$ Porém, também na faceta precisa dos que concebem a internet como uma espécie de atualização de Hefesto: do technical boy (um dos deuses americanos que representa justamente a internet e a tecnologia), de Neil Gaiman, até as iniciativas práticas que pretendem organizar instituições religiosas para adorar a Inteligência Artificial (Al) enquanto estatuto religioso. (Cf. a Way of The Future: http://www.wayofthefuture.church/).
} 
experiência têm a ver com uma lida diretamente com a perda, com a morte do outro, com a finitude do outro.

Tal dimensão apresenta uma necessidade de estabelecermos um referencial teórico, que além de abrigar e perpassar conceitos gerais que abarcam uma Psicologia da Morte, se direcione para a necessidade de pensarmos o luto. Os respondentes do questionário e da entrevista passaram por uma experiência precisa que exige um trabalho, ou uma operação simbólica, para ser ultrapassada: a dimensão do luto é central para a pesquisa e no próximo capítulo refletirei um pouco sobre o tema. 


\section{Sobre o luto}

Escrever sobre o luto exige certas circunscrições: aqui, o luto será entendido sempre como uma experiência da presentificação de uma ideia, ainda que fugidia, da morte e de uma perda de comunicação com alguém amado. É sobre o luto de alguém amado, querido ou ao menos conhecido, alguém que suporíamos uma relação, que iremos adotar como referência para iniciar uma reflexão. Essa é uma problemática central nas teorias que tratam o luto como um trabalho ou elaboração decorrente de uma perda do objeto e uma superação através da substituição do mesmo. Ainda que pudéssemos desdobrar o conceito em seu radical, a dizer, de uma perda inaugural, constituinte de um efeito de sujeito, é preciso demarcar o conceito de uma forma mais precisa: o enlutado é aquele que se depara diretamente com a ideia da morte, com sua aparição, signo de presença, e que ao mesmo tempo que se depara com tal realidade, perde um possível, que se refere à comunicação com alguém que lhe era importante. A conversão de um possível em um impossível, a ruptura de uma pretensa comunicação, a realidade de um corte: um antes e um depois, intangíveis. A teleologia do ser humano, falante, que se depara com o depois, é a constatação do impossível: o real da morte é justamente a impossibilidade de um diálogo com aquele que se foi.

Mas o luto não se trata dessa perda; se trata, justamente, de uma operação simbólica que possibilite que se perca de si, algo do outro em ti, um "pequeno pedaço de si”, como denomina Allouch (2004). Um sacrifício que condiciona o próprio rito.

Se toda direção de um modelo freudiano de amor envolve um movimento anaclítico, que retorna e remonta aos afetos infantis, que pendula em uma dialética entre as referências internas e uma percepção possível de realidade, se o par dentro/fora já não pode ser concebido como uma antinomia, toda perda é desde-antes e sobretudo uma separação, um corte. Esse é o ponto chave também de uma antropologia na lida com o luto: o ritual existe para simbolizar, estabelecer ou delimitar uma passagem, um corte entre o mundo dos vivos e o dos mortos. Bem realizado, impediria que a ambivalência dos sentimentos, nutridos em relação a figura do morto retornassem com a ira do fantasma - as vezes materializado, em medo de espíritos ou do além - e que perseguiria aqueles que ficaram insistentemente. $\mathrm{O}$ rito permite que a vida do morto esteja conclusa. Lacan (2016, p. 360) sublinha, sobre o rito: “[...] Se, do lado do morto, daquele que acaba de desaparecer, não se cumpriu algo designado como ritos, surgem então aparições singulares", e exemplifica com o ghost, o fantasma, em Hamlet. 
Freud (2014), em seu mais organizado trabalho sobre o luto, Luto e Melancolia, define o luto como um "afeto normal" (Id. p. 45). Sua perspectiva de um luto envolve a perda de uma pessoa querida (ou de uma abstração enquanto sentido, um ideal), via de regra uma "perda real, a morte do objeto" (Id. p. 81). Dependente de uma dinâmica que envolve o próprio tempo, se trataria de um processo que se refere a perda dos interesses por tudo aquilo que concerne ao "mundo externo" e até a um possível novo objeto de amor (Id. Ibid.).

Seu texto é muito interessante e descreve uma verdadeira operação: tal dinâmica nesse ponto estaria concentrada em uma relação com a "memória do morto" (op. Cit.). Assim, uma certa dificuldade de abandonar uma "posição da libido", sustentada através das lembranças e expectativas ao objeto. O que Freud chama de Kompromissleistung, uma operação de compromisso, de compromisso mesmo com algo da ordem da realidade - especificamente a de que a pessoa querida já não se encontra mais entre os vivos - livraria e desinibiria o ego de tal relação. Operação dolorosa, mas que encarna uma espécie de caminho ideal, ou de um luto enquanto "afeto normal".

Por outro lado, o luto se constituiria em um momento no qual se afloram as disposições: por exemplo, na neurose obsessiva, o conflito de ambivalência poderia desencadear uma "conformação patológica", que envolveria culpa e auto recriminações em relação ao paradoxo de uma "perda desejada" (Id. p. 65).

Creio ser interessante aqui, que Freud (Id. p. 77) se refere, nessa dinâmica, às "recordações e situações de expectativa" enquanto ligadas ao objeto perdido, em um movimento que se defronta com uma realidade de um objeto aniquilado, que não existe mais.

Esse é um dos pontos que tencionamos ao pensar nessa dinâmica a partir do momento em que os perfis de falecidos nos websites de redes sociais (WRS's) se apresentam aos vivos em uma constante aparição, movimento que poderíamos definir como insistente. Se evocam ou não os traços inconscientes, as "impressões singulares", aquilo de que seria preciso abandonar, retirar a libido, se passa a transformar o processo em algo mais moroso ou não. Dito de outra forma, se poderia atrapalhar um luto razoável ou não.

Enquanto execução minuciosa, o luto se transformaria efetivamente em um trabalho, o de desfazer os "milhares de laços" (Id. p.81) que sustentavam uma relação.

Allouch (2004, p. 21) faz uma crítica a noção de luto enquanto trabalho, que considera uma leitura romântica de Freud sobre o luto: uma noção de trabalho penoso que se resolverá em uma 
dialética própria do tempo e de um desinvestimento pulsional que recairá ou despontará para outro objeto eleito:

“[...] Freud não escreveu esse artigo para estabelecer uma versão psicanalítica do luto, como quase todos após ele dizem, ou creem, ou querem crer, tomando por ponto de apoio uma versão não crítica do luto, Freud quis, assim, conquistar a melancolia [...] Fez-se do luto um...trabalho, embora o termo Trauerarbeit só figure, no total, uma única vez no artigo".

Transformar o luto em um trabalho poderia então ser interpretado como propriamente uma ideologia, mas, mais que isso, se transformaria numa espécie de prescrição normatizante que funcionaria como um "antidepressivo" (Id. Ibid.), e essa teria sido a noção praticamente adotada pela primeira geração e inúmeras escolas que fizeram de tal ensaio um ponto de partida, uma referência para pensar luto na psicanálise e nas psicologias: uma noção dual de objeto que reduz a comunicação entre duas pessoas à ideia de duas entidades autoconscientes, individuais, se relacionando a partir de uma linguagem compartilhada de forma congruente, sem graves equivocações.

Porém, apesar da crítica, a sugestão de Allouch (2004, p. 11), de elevar o luto ao estatuto de ato, iria de encontro com a proposição freudiana que se encontra em textos retro referidos, como a transitoriedade e nossa atitude perante a morte (não ao acaso publicados respectivamente em 1916 e 1915). Ou seja, a ideia de retomar o macabro em sua função de suscitação do desejo no vivente, está constantemente presente na proposição freudiana, inclusive em sua ética: Si vis vitam, para mortem.

Enquanto ato, Allouch (2004) propõe o luto como um "gracioso sacrifício", uma espécie de segunda morte, uma perda seca desse alguém que já fora perdido, assim “de desaparecido esse alguém adquire o estatuto de inexistente. Assim, ele cessa de possivelmente aparecer, tal um fantasma ou alucinação" (Id. 389). A questão, para Allouch, é que tal ato depende de uma operação que sacrifica um "pequeno pedaço de si”. É interessante que, apesar da crítica em relação ao Luto e Melancolia, Allouch (Id. Ibid.) estabelece um par oposto, ou um "desvio", justamente aquele que se caracteriza por uma perseguição, de um enlutado que reivindica esse pedaço de si junto ao morto, e de um morto que o reivindica junto ao enlutado: noção que aparece diversas vezes em Freud, sobretudo quando se refere à antropologia na questão da ambivalência, em Totem e Tabu (2013).

Ao longo dos outros capítulos, também citei teóricos da Antropologia da Morte e o próprio Levi Strauss, que apontam para o fato de que quando a operação simbólica não é realizada de acordo com o rito devido, os mortos voltarão para atormentar os vivos. Não ao acaso, em sua passagem 
mais "didática" sobre o luto, Lacan (2016, p. 361) escolhe a tragédia de Hamlet para ilustrar a as "aparições singulares" em um luto não satisfeito: “[...] se algo da satisfação devida ao morto fica faltando, é elidido ou recusado, então se produzem todos os fenômenos decorrentes da entrada em jogo, do acionamento da influência, dos fantasmas e das larvas no lugar deixado livre pela ausência do rito significante".

É também interessante que no movimento que Allouch (Id. Ibid.) descreve como o "gracioso sacrifício do luto", o ajuntamento dos objetos dos mortos é oferecido ao nada e o autor até dá o exemplo dos faraós que ajuntavam seus pertences e tomavam "mil precauções para que seus túmulos não fossem pilhados"10.

Creio que quando Freud (2014) se refere à "memória do morto", "recordações" e "situações de expectativa", está justamente falando de um "nada” que liga o enlutado ao objeto, um nada que dependeria de uma "segunda morte"; o ato, que eu também chamaria de romântico - sem nenhuma conotação negativa - de um gracioso sacrifício de luto, de um sacrifício do pequeno pedaço de si, do qual aliás poderíamos fazer um paralelo concreto com alguns rituais sagrados. Dois exemplos contundentes: no caso dos judeus, a obrigação precisa de rasgar a própria roupa (Keriá) antes de levar o corpo para o enterro; no qual o enlutado permanece de pé, e realiza um corte vertical, de não menos que 8 centímetros - o que endossa a ideia do sacrifício e que claramente se trata de um ato público - e o enlutado deve vestir a roupa com o rasgo por 7 dias. O segundo, no caso da tribo Dani, em Papa Nova Guiné, na qual os membros cortam pedaços dos próprios dedos durante os ritos funerários (Sumitra, 2011). Rituais análogos podem ser encontrados em diversas partes do mundo.

A questão é que, como aponta Costa $(2015$, p. 64), "não é suficiente a perda estar colocada na realidade".

O que diferenciaria radicalmente a ideia de luto em Lacan e em Freud seria justamente que, se para Freud, algo da identificação é explicado pela "incorporação do objeto perdido", que Lacan (2016, p. 360) ilustra bem com a cena de Laertes pulando na cova e beijando o "objeto cujo desaparecimento é causa dessa dor”, e então encontramos uma ideia em Freud de substituição - de que findo o trabalho de luto - o sujeito redirecionaria seu laço para um outro objeto amado ou em direção à realidade. Porém, em Lacan (Id. Ibid.), se se trata então de um objeto que existe, mas corresponde à "mais nada que exista", como na cena de Laertes, então o luto é uma perda

${ }^{10}$ Para avalizar tal constatação precisaríamos fazer um estudo minucioso do lugar de destino dos objetos próprios no Livro dos Mortos, que se tratava sem dúvida do manual/programa egípcio para o pós-morte. 
verdadeira que "lhe provoca um buraco no real". Lacan (Id. Ibid.) propõe uma fórmula exatamente inversa da qual apresentou como Verwerfung, de que o "que foi rechaçado no simbólico reaparece no real". Deveríamos então, ler assim: o que foi rechaçado no real reaparece no simbólico.

Por isso, para Lacan (Id. Ibid) o trabalho do luto se refere ao logos, em uma satisfação:

"dada à desordem que se produz em razão da insuficiência de todos os elementos significantes em fazer frente ao buraco na existência. É todo o sistema significante que é posto em jogo em torno do menor luto que seja"

Se para Freud, além da importância do rito, o luto envolve o movimento de se desatrelar de uma "memória do morto", para Lacan, o rito enquanto ato mobilizaria todo o jogo simbólico para satisfazer a memória do morto e conceber sua vida como conclusa. Em ambos, o sacrifício de um "pedaço" do morto em si é necessário: “[...] esse significante, só podemos pagá-lo com nossa carne e nosso sangue" (Id. Ibid.).

Allouch (2004), descreve um modelo de luto que envolve uma passagem do sintoma para a angústia, que do lado do morto, realizaria o estatuto de uma vida cumprida. Me parece que, apesar da refusa de uma "psicologia freudiana do luto", algo bastante parecido com a última etapa da proposta freudiana aparece: livre de uma relação por vezes ambivalente com o objeto perdido, concluso um fecho em relação ao fim da vida do morto, aquele que perdera alguém pode então realizar novos encontros com um outro e se interessar novamente por outras questões que não somente as que se referiam ao morto. Para isso, é preciso sacrificar esse pequeno pedaço de si, o sujeito "[...] precisa perder para que seja possível a constituição de um trabalho de luto" (Costa, p. 64).

Se o artista precede o psicanalista, o escritor português contemporâneo José Luís Peixoto (2018) ao escrever uma penosa e difícil despedida ao seu pai, falecido, elege um título para a obra que bem resume e encerra a questão do luto: "Morreste-me".

Toda essa penosa operação demarca uma separação. Aquele que se encontra no processo de realizá-la se denomina enlutado. Diversas são as variações dessa nomeação. Maria Rita Kehl (2018) levanta uma questão interessante sobre uma modalidade específica de luto: a daqueles que perdem o filho(a). De acordo com Kehl (Id.) é algo tão doloroso e "antinatural", que não existe uma palavra para nomear tal categoria: "Quem perdeu os pais é órfão, quem perdeu esposo(a) é viúvo(a). Quem perdeu filho ou filha, torna-se o que?”. A autora está certa que, ao menos no português, não encontramos uma palavra para nomear, "agasalhar", simbolizar, circunscrever tal categoria. Nos Estados Unidos, um grande movimento de pais que perderam 
seus filhos decidiu cooptar uma palavra do sânscrito que pudesse denomina-los: Vilomah. Vilomah significa justamente “... contra a ordem natural” (Holloway, 2009), talvez um termo ideal para nomear aquele que passa por uma experiência tão devastadora.

Essa modalidade específica do luto é muito significativa, e para Allouch (2004) ${ }^{11}$ se trata do paradigma do luto contemporâneo, que se em Freud era a morte do pai, no contemporâneo seria a morte do filho. Não entrarei em um recorte histórico pois levaria a digressões incontáveis, inclusive na direção de uma suposta queda do falocentrismo ou da autoridade paterna no contemporâneo.

Entretanto, Parkes (1998), em uma obra que faz um levantamento bibliográfico muito completo sobre pesquisas que versam sobre o luto, aponta que as reações no caso dos pais que perderam filhos são muito diferentes e mais devastadoras de que as do "luto comum", sobretudo em relação ao luto dos pais, naturalmente mais frequente. Realidade muito diferente da de um passado no qual a mortalidade dos bebês era muito alta:

"[...] há evidências de que, em tempos passados, quando a maioria dos pais poderia esperar perder metade do número de filhos que tivesse, quando bebês ou na primeira infância, eles aceitavam essas perdas mais prontamente do que hoje" (Parkes, 1998, p. 150).

Por último, se “[...] os rituais funerários nos ensinam que, no momento em que se produz uma perda, esta não é substituível” e que é preciso "inscreve-la num laço - seja nos rituais, nas experiências de escrita, como o fazem tantos imigrantes na literatura e as arte" (Costa, p. 64), é importante pensarmos se a função dos perfis de falecidos poderia se equivaler justamente à tal tentativa de inscrição. Por exemplo, se exerce tal função aos deslocados geograficamente, aos que não podem operar o rito por interdições diversas ou simplesmente àqueles que precisam escrever algo para o morto e depois sobre o morto.

Afinal, se a prática escriturária é memória, só “constrói-se a partir do nada (nichts: não tenho nada a perder) e da obrigação (não te esquecerei)" (Certeau, 2011, p. 351). Certeau (2011), ao pensar nos ensaios freudianos sobre Moisés, determina a escrita enquanto tradição de uma morte:

“[...] o texto freudiano nos conduz a esse ponto em que a relação entre o assassinato de Moisés e a produção da tradição designa a natureza íntima do luto como inscrição. Elucidação "sacrílega" sem dúvida, pois rouba ao

${ }^{11}$ Que na abertura de sua obra conta de sua experiência pessoal: enquanto filho, perdeu o pai. Enquanto pai, perdeu uma filha. 
sagrado (legere sacrum) o que lhe é essencial - a presença -, se é verdade que fazer o seu luto é escrever." (id, p. 353).

Dessa forma, se o luto é também escrever, qual a função dos perfis de falecidos, escritos por aqueles que se foram; lidos, visitados e atualizados pelos que ficaram?

Tais questões emergem de forma bem destacada na análise de dados do questionário, naquilo que se sobressalta do que os respondentes escrevem sobre o próprio luto. Sendo assim, os próximos capítulos irão apontar alguns temas que emergiram para além das revisões bibliográficas e organizações teóricas sobre a morte e sobre o luto. A proposta, a partir daqui, será justamente se deparar com o que pode ser dito por aqueles passaram por um luto em tempos de redes sociais. 


\section{Método}

Antes das análises do questionário e das entrevistas, falarei um pouco sobre o método adotado para estruturar esse trabalho. Isso poderá ajudar o leitor a se localizar e acompanhar as etapas de sua produção. Os primeiros capítulos se referiam a revisões bibliográficas e teorizações sobre o sujeito no campo digital, morte, luto, e outras circunscrições em relação ao campo de pesquisa. Tais reflexões foram construídas a partir de indagações teóricas e dúvidas que surgiram perante categorias elencadas por outros trabalhos. Até o momento, o trabalho se preocupou com conversações necessárias entre diferentes teorias, tentando marcar com precisão uma reflexão sobre o luto nos WRS's.

A partir daqui o leitor se deparará com um questionário que fora inspirado na pesquisa de Brubaker et. al. (2013), a partir dos temas com os quais os pesquisadores organizaram entrevistas com enlutados.

Antes, levantarei alguns pontos de consideração sobre esta inspiração metodológica:

As perguntas que nortearam o trabalho de Brubaker et al. (2013) foram: Como as práticas de memorização online se conectam aos convencionais rituais de aflição e luto? Como se prossegue a identidade digital depois da morte? Como as trajetórias da morte e do morrer incorporam tanto preocupações offline quanto online?

Em sua pesquisa, as entrevistas foram conduzidas com americanos, o que colocou o trabalho em uma esfera de contexto ocidental, mais especificamente 16 indivíduos (entre 24-57 anos, 9 mulheres), que relataram experiências relacionadas a morte em WRS's. Os participantes se aproximaram a partir dos próprios grupos sociais dos pesquisadores, e três deles eram oriundos do Canada, Japão e Índia, porém refletiam uma perspectiva americana sobre a morte (Brubaker et al., 2013, p. 10)

Foram realizadas entrevistas abertas, permitindo que os participantes guiassem as discussões de acordo com os tópicos que lhe interessavam mais, mas direcionando as aproximações sobre a morte, mídias sociais e outras tecnologias de comunicações, sobretudo no que se referia às interações e experiências relacionadas a morte no Facebook. Os participantes foram incentivados a relatar histórias e experiências de contato com a morte no Facebook: a primeira vez que se depararam, como ocorreram esses encontros, como esses perfis participaram das 
redes; também refletiram sobre suas preferências em relação a gestão de suas contas pós-morte (Brubaker, 2013, p. 11)

Todos os participantes descreveram encontros com ao menos um perfil de falecido no Facebook, a maioria tendo experiências com dois ou três (Id. Ibid).

Ainda em tal pesquisa, as entrevistas duraram entre 1 e 2 horas: 8 delas foram conduzidas pessoalmente, 4 foram via vídeo chat, e 4 foram por telefone. Os participantes que foram entrevistados pessoalmente foram gravados por um laptop e também compartilharam com o entrevistador o perfil do falecido sobre o qual falavam. As partes significativas das entrevistas em vídeo chat também foram gravadas. Os participantes também compartilharam com os pesquisadores e-mails, obituários, notícias, grupos públicos do Facebook, e blogs que se relacionavam ao assunto (Id. Ibid.) A análise das entrevistas foi feita a partir da divisão de temas, dividindo-os em determinadas categorias que surgiram a partir das falas dos entrevistados, a literatura da área e descobertas precedentes, para então definir grandes categorias como "encontros inesperados". Esses temas foram usados para organizar dedutivamente as falas dos entrevistados (Id. Ibid.).

Creio que poderíamos chamar a análise de seu trabalho de categorial. Ao elencar algumas categorias e elaborar reflexões derivadas delas, os autores chegaram em algumas considerações e dividiram a ideia de expansão no uso dos WRS's em três categorias (Id. p. 29):

Expansão temporal: A flexibilidade de um meio assíncrono (particularmente sobre as notificações da morte) e o entrelaçamento da morte no que diz respeito às experiências cotidianas nas redes sociais.

Expansão espacial: A supressão das barreiras físicas.

Expansão social: A disseminação da informação e práticas de luto e o colapso do contexto na auto representação online.

A natureza assíncrona dos meios de comunicação que se referem aos WRS's faz com que parte dos usuários continuem se engajando com perfis pós-morte, compartilhando memórias, novidades e falando com o morto. Como resultado, é visto um entrelaçamento entre a morte e o luto no cotidiano, diferente da conjuntura contemporânea que se refere às práticas rituais dos funerais e memórias tradicionais. A pesquisa encontra uma tristeza particular em relação aos usuários que sabem da morte de um conhecido de forma tardia (Brubaker et al, 2013, p. 31). 
Tais pesquisadores também definiram a ideia de um memorial ativo como um arquivo ativo: conjunto de memórias que encontra uma infraestrutura para estabelecer novos relacionamentos com seus "passados sociais": romances que falharam, embaraçamentos passados e também amigos falecidos que são novamente inseridos no uso cotidiano dos WRS's (Id. Ibid.).

Já a expansão social concerne à queda das barreiras geográficas, o que produz uma espécie de luto compartilhado a partir de uma gama maior de localidades. A barreira física já não se transforma em uma interdição para as práticas de memorização em torno do ritual de luto. Os usuários lidam com outros "sobreviventes" e suas diferentes formas de expressar o luto nos WRS's; o que pode gerar também estranhamento entre as diversas imagens apresentadas pelo meio social do falecido. O impacto dessa expansão abre um grande leque de questões sobre o impacto dessa supressão geográfica, que pode sensibilizar, intimidar ou tocar no que tange a questões morais de como cada usuário lida com a morte.

A expansão da ideia de morte nos WRS's encontra sua máxima na ideia de expansão social: a disseminação de informações nos WRS's unifica grupos sociais que eram previamente separados e se conectam a partir da morte de um usuário, compartilhando interesses ou atividades para interagir a partir de um design alternativo e gerando três diferentes efeitos, que expandem socialmente a partir dos WRS's: a inclusão de relacionamentos casuais, indivíduos de diferentes contextos e a expansão que então inclui o perfil do morto. A notícia da morte chega para amigos de diferentes contextos sociais: trabalho, casa, entre passado e presente de uma forma simétrica nos WRS's, com reações diferentes e públicas (Id, p. 35).

A expansão social sobretudo inclui o falecido no espaço social dos WRS's, isso é uma nuance bem delicada pois em determinado nível, existe uma continuidade desse falecido no grupo social dos "sobreviventes" (Id. Ibid.), o que determina ações, muitas vezes como se esses perfis pós-morte pertencessem ao mundo dos vivos: compartilhando memórias, conversando, lidando com diferentes imagens e narrativas de diferentes grupos sociais.

Tal pesquisa fora muito importante enquanto inspiração teórica e de método para a minha e muitos dos pontos levantados pelas categorias com a qual Brubaker et al. (2013) trabalham, além de se tornarem referenciais para pensar nas perguntas adotadas no questionário que construí, foram adotadas enquanto referência em todo o percurso teórico tecido na pesquisa.

Decidi então, além das reflexões teóricas, elaborar um questionário baseado nos temas que emergiram na pesquisa de Brubaker et. al. (2013), para visualizar e trabalhar com temas que emergiriam a partir das respostas. Além disso, realizei duas entrevistas com um formato 
análogo ao realizado pelos pesquisadores, para pensar se poderiam emergir assuntos diferentes quando o interlocutor não fosse estimulado por determinadas questões, que sempre pressupõem algum grau de arbitrariedade. As duas entrevistas duraram entre 30 e 40 minutos, foram feitas pessoalmente, gravadas por um aplicativo de gravação de voz e se encontram integralmente nos Anexos. Os entrevistados foram orientados sobre o tema da pesquisa, mas nenhuma pergunta fora feita como introdução, deixando-os falar o mais livremente possível sobre o assunto e seus desdobramentos.

As respostas do questionário foram divididas de forma qualitativa, a partir de temas que convergiam e divergiam entre si. Assim, isolei algumas categorias, levando em conta a concepção de Bardin de análise categorial, a partir de "desmembramentos do texto em unidades" e "reagrupamentos analógicos" (Bardin, 2011, p. 153), para então determinar temas e analisar as respostas a partir desses eixos temáticos.

Os mesmos critérios temáticos utilizados para analisar as respostas do questionário também fizeram parte da análise das entrevistas, para poder compara-los. Precisei levar em conta a minha escuta durante as entrevistas, em um movimento que Bardin chamou de pré-análise (Id. p. 96): desta, também fez parte a transcrição e uma "leitura flutuante", na qual me deparei com as entrevistas já transcritas a partir das hipóteses emergentes e de materiais análogos, já analisados.

Nesse movimento, durante as entrevistas (Anexo 1 e Anexo 2), realizei pequenas intervenções para tentar elucidar alguns pontos sobre o que o entrevistado falava. Tal consideração obriga incluir o entrevistador na perspectiva. Além dessa variável, Bardin (2011, p. 119) faz uma observação muito interessante sobre a crença de que o isolamento das categorias eliminaria as variáveis e corresponderiam a índices absolutos próprios das respostas:

"A análise de conteúdo assenta implicitamente na crença de que a categorização (passagem de dados brutos a dados organizados) não introduz desvios (por excesso ou por recusa) no material, mas que dá a conhecer índices invisíveis, ao nível dos dados brutos. Isto talvez seja abusar da confiança que se pode ter no bom funcionamento deste delicado instrumento. É preferível estar-se consciente do que se passa quando da efetuação de uma operação de tal modo habitual que parece anódina."

Porém, creio que os elementos que implicam o entrevistador e o precedente bibliográfico que conduzem a inspiração e condução teórico-metodológica da pesquisa estão expostos tanto no método quanto no percurso teórico. 
Em contrapartida ao modelo de análise de conteúdo que Bardin (Id. Ibid.) apresenta, as categorias foram apresentadas com algum grau de flexibilidade própria da ambivalência de alguns temas, como quando os respondentes eram perguntados sobre se a experiência de contato com o perfil de falecidos fora boa ou ruim. Nesse caso, uma resposta que considerasse boa e ruim seria perfeitamente considerável e abrigada em uma consideração.

Em outras palavras, o método não objetivou eliminar incongruências ou equívocos nas respostas ou categorias, mas, ao organizá-las a partir de tal análise, destacá-las e levá-las em consideração, tanto na relação delas com elas mesmas quanto em relação as pesquisas precedentes ou determinadas questões teóricas, como o leitor perceberá em alguns casos. 


\section{Análise de dados}

Nesse capítulo apresentarei os dados extraídos do questionário aplicado através da plataforma Survey Monkey, disponível entre os meses de março e agosto de 2018, totalizando 6 meses. O questionário fora divulgado através da lista de contato do pesquisador e de seu círculo social, compartilhando o máximo possível. Além disso, fora publicado em comunidades do Facebook e através de lista de e-mails. O número de respondentes chegou a 173 . Irei comentar alguns dados que se sobressaíram de maneira progressiva, tentando seguir a mesma organização da apresentação do questionário e os dividindo em categorias através de temas que emergiram, estabelecendo conversações entre as mesmas. No final do capitulo, também apresentarei duas entrevistas realizadas com pessoas que perderam alguém que possuía um perfil no Facebook.

\section{Distribuição dos respondentes}

Na Figura 1 podemos visualizar a distribuição geográfica dos respondentes brasileiros. Entre os respondentes, o questionário contou com a preponderância do estado de São Paulo (123), mas teve rica distribuição e participantes de 14 estados: Alagoas (1), Bahia (2), Ceará (1), Goiás (1), Maranhão (5), Minas Gerais (2), Pará (2) , Piauí (1), Rio de Janeiro (10), Rio Grande do Sul (4), Rondônia (2), Santa Catarina (3), Brasília (1), além dos Estados Unidos (1), Portugal (1) e Alemanha (1). Além disso, 13 respondentes anotaram apenas "Brasil" na caixa de respostas. 


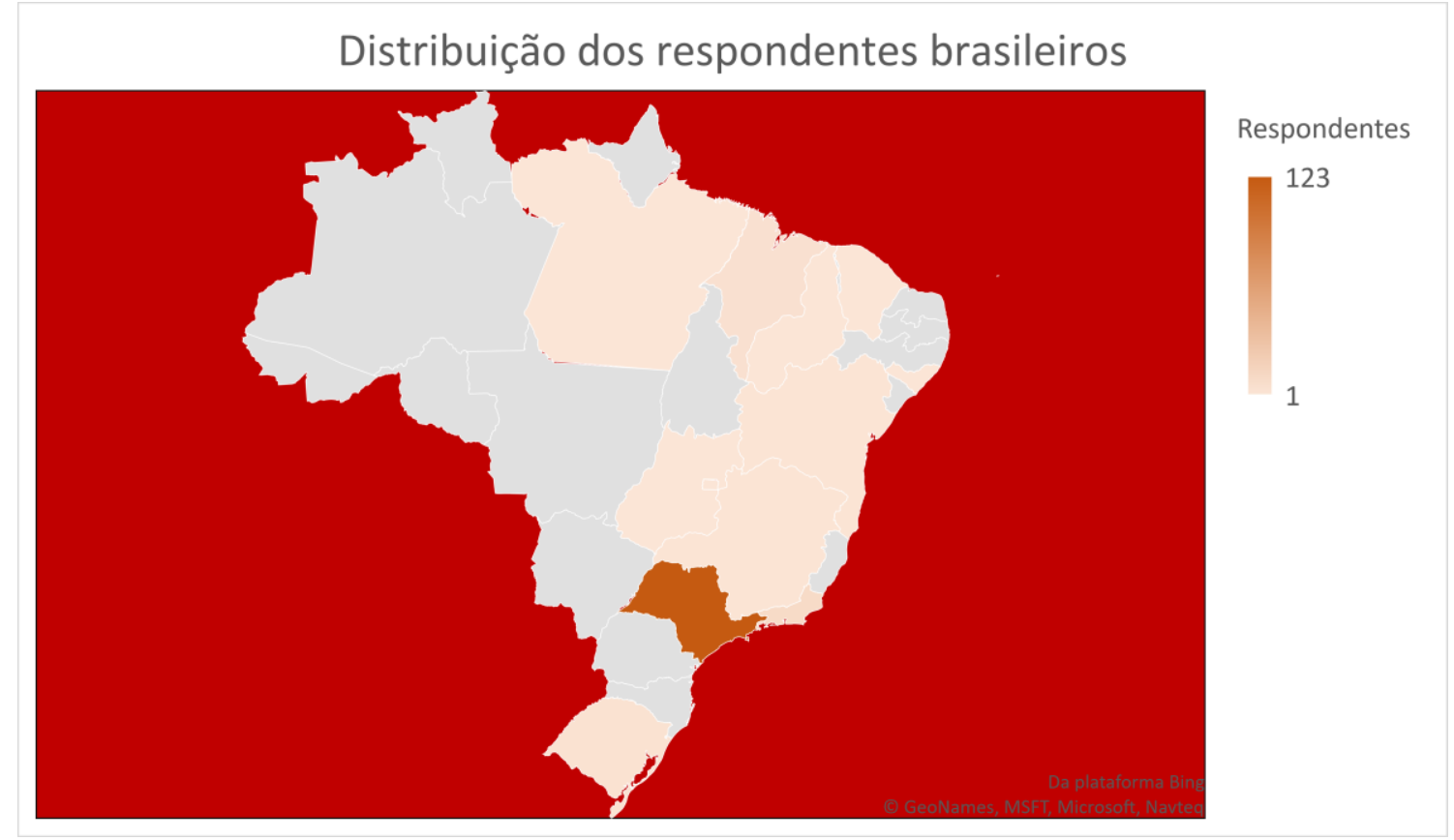

\section{Gênero}

A terceira questão proposta, depois de idade e uma elucidação sobre o sigilo dos dados na pesquisa, era sobre o gênero dos respondentes. Como podemos vislumbrar na Figura 2, dos 163 que marcaram alguma alternativa, $113(69,33 \%)$ eram mulheres e 50 (30,67\%) eram homens. Ainda disponibilizei uma caixa com a opção “outros", porém nenhum respondente a marcou. Figura 2

\section{Q3 Gênero}

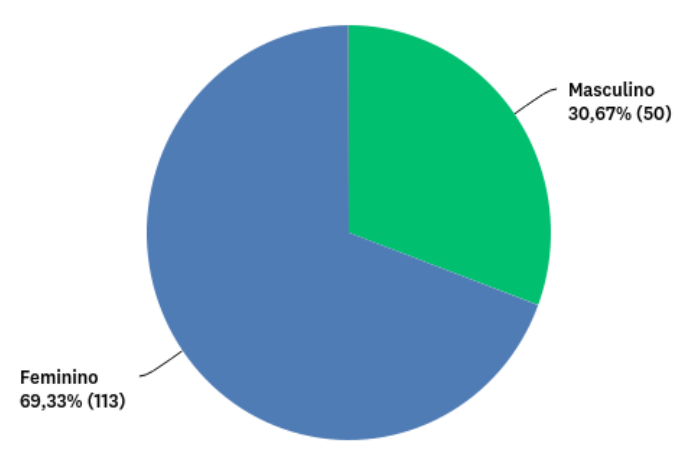


O predomínio de respondentes mulheres me chamou a atenção para a questão do gênero no luto. De acordo com Parkes (1998) as mulheres costumam apresentar mais problemas psicológicos no luto que os homens. Porém, o autor chama a atenção para um dado especial: que os homens "apresentam maior tendência a morrer de ataque cardíaco depois da morte do cônjuge" (Id. p. 152). Apesar de não saber exatamente porque, o autor infere que talvez a tendência do homem seria a de pedir menos ajuda e esconder os próprios sentimentos. A pesquisa de Brabant et al. (1992) corrobora com tal hipótese: ao realizar entrevistas com homens que perderam suas esposas, não encontraram elementos que justificassem que homens sintam menos a morte de suas parceiras que as mulheres; pelo contrário, nestes casos, a morte evocou intensos sentimentos e os entrevistados sofriam e tinham consciência do próprio sofrimento. A diferença fundamental é que eles não procuravam ajuda de alguém para lidar com isso.

Parkes (1998) supõe que exista um efeito psicossomático diante dessa repressão e que isso poderia desembocar na consequência cardíaca. Apesar de ser tentador endossar tal hipótese, de que aquilo que não conseguimos expressar, narrar, descrever, pode atravessar o corpo e se fazer presente em alguma patologia, é preciso muito cuidado com tais associações.

Um interessante estudo de Bonanno et al. (1995) coloca em xeque tal hipótese e considera que possa existir uma "função adaptativa" em evitar falar e lidar com sentimentos dolorosos que acompanham o luto. Ainda assim, independentemente do gênero, algumas pesquisas apontam uma relação intrínseca entre o infarto e o luto, sobretudo o não-elaborado (Ruschel, 2006). Em um estudo brasileiro, Jurkiewics e Romano (2009) fizeram um levantamento com pacientes internados por infarto agudo no miocárdio e angina e realizaram que "a vivência de perdas e o consequente estado de luto são fatores psicológicos frequentes nas manifestações da DAC (Doença Arterial Coronariana)". Tal constatação desvela a linguagem e a significação do "coração partido" pela perda de alguém querido em seu estatuto de metáfora. Porém, devemos examinar a relação direta de causalidade com precaução: associação não significa que ele seja automaticamente causa mortis: "o fato de o luto poder levar à morte em razão de doenças cardíacas não prova que ele seja, isoladamente, uma causa de morte [...]” (Parkes, 1998, p. 34).

Voltando à questão que se apresenta na preponderância feminina entre os que se dispõem a participar do questionário: em sua vasta experiência, Parkes (1998) conta que no Serviço de Aconselhamento da Universidade McGill, entre 1945-1951, dos 171 pacientes encaminhados por situação de luto, $83 \%$ eram mulheres; e que os homens, além de muito raramente procurar ajuda para lidar com a situação, se veem na responsabilidade de ocultar suas manifestações de 
luto para amparar a esposa em casos de filhos natimortos. Tal categoria de luto e também o óbito fetal são especialmente e extremamente dolorosos para a mulher (Lemos e Cunha, 2015). A questão de gênero é um recorte importante para se pensar o luto e novas pesquisas, sobretudo comparativas, que podem ser importantes para elucidar o maior número de mulheres que buscam acompanhamento por causa de tal situação. Da lida com a perda, da maternidade, das identificações, posições e a própria eleição de gênero, a experiência feminina e a masculina do luto podem ser diferentes e esse é um campo de trabalho passível de diversos recortes, todos importantes para trabalhar com enlutados.

\section{Idade}

A idade dos participantes foi outro elemento perguntado. Na Figura 3, percebemos que o número de respondentes entre 20 e 50 anos correspondem à $80 \%$ dos participantes. Podemos realizar que o interesse dessa faixa etária foi significantemente maior que entre os menores de 20 anos e os com mais de 50. Porém, é também interessante o fato de nos depararmos com 14\% dos respondentes acima de 50 anos, afinal, por se propor a trabalhar com um questionário online, que obriga o participante a entender ao menos o mínimo de navegação, eu esperava que houvessem muito mais respostas dos denominados nativos digitais, dos jovens que já cresceram com a web enquanto parte essencial do cotidiano. 


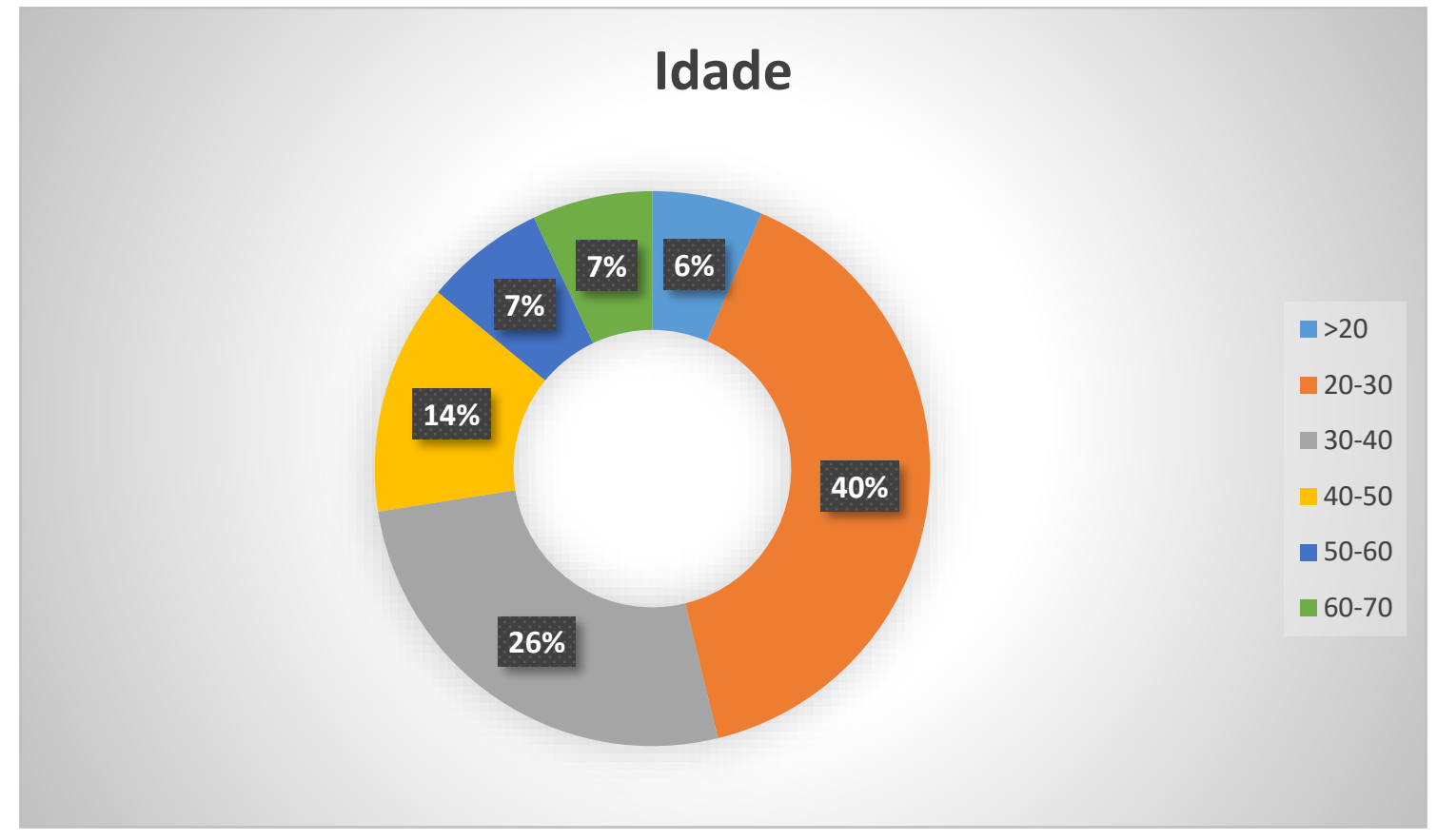

Apesar da preponderância dos adultos e jovens adultos como respondentes, as reações consideradas agudas ao luto não são exclusividade dessa faixa. O luto é causa de depressão nas idades avançadas, assim como é considerado um relevante fator para aumento de mortalidade entre os mais velhos (Parkes, 1998). Os dois respondentes mais velhos do questionário tinham igualmente 70 anos. Um deles, um homem que perdeu um amigo(a) também de 70 anos e que revela uma função interessante do Facebook: avisar sobre o falecimento de alguém. Na opção sobre formas de interação com o falecido, o respondente marcou que não tivera nenhuma interação e então abandonou o questionário. O segundo caso, de uma senhora de 70 anos, que perdera um amigo (a) de 71, relata certo espanto ao realizar que o perfil do amigo (a) continuou sem mudanças na rede: "Eu fiquei espantada com essa possibilidade. Não me afetou, mas acho mórbido quando aparece o dia do aniversário como se ele estivesse vivo”. Na opção sobre o destino do próprio perfil depois de sua morte, assinalou que gostaria que o mesmo fosse deletado da rede.

Grande parte das pesquisas que se propõem a trabalhar com a questão do luto no idoso focam em uma perda de cônjuge, nos casos de viuvez e no caso da perda dos filhos (Cf. Oliveira e Lopes, 2008), além de uma multiplicidade de perdas que podem estar atreladas a isso: renda, casa, entre outros (Parkes, 1998). Se considerarmos a acepção de luto como referente as perdas de uma forma mais genérica, o próprio processo de envelhecimento está conectado as perdas 
motoras, de vigor, em uma relação que se transforma com o próprio corpo. Lembremo-nos que foi na mesma idade dos 70 anos que Freud concedera a famosa entrevista a Sylvester Viereck:

"Talvez os deuses sejam gentis conosco, tornando a vida mais desagradável à medida que envelhecemos. Por fim, a morte nos parece menos intolerável do que os fardos que carregamos" (Freud, 1930 apud Franco e Wondracek, 2007).

E, propriamente pela ordem do necessário, o idoso costumeiramente experimenta sucessivas perdas de pessoas queridas (Parkes, 1998), na medida em que a idade vai avançando.

$\mathrm{Na}$ outra ponta da questão da idade estão as crianças. A forma que as crianças concebem a ideia de morte é uma questão específica de todo um campo de estudos. Alguns pesquisadores apontam para a idade entre 5 e 7 anos para que a criança tenha uma noção da ideia de morte que agrupe quatro elementos: irreversibilidade, universalidade, não-funcionalidade (a "parada do corpo") e causalidade (a morte como degeneração, doenças, e não apenas como um acidente) (Paiva, 2007). Outros estudos atribuem uma apreensão geral da morte como inevitável, universal, irreversível e pessoal entre os 9 e 10 anos (Id. Ibid.). Os caminhos possíveis são muitos, sobretudo se pensarmos no luto enquanto perda de objeto, na relação entre morte e gozo e outras hipóteses sobre a constituição da criança. Em nosso questionário, apenas uma criança foi respondente.

Um menino de 12 anos respondeu o questionário de forma um pouco confusa: apesar de demarcar que não conhecia alguém que possuía um perfil e faleceu, afirma que teve interação com um perfil de um usuário falecido, assinalou que a existência e interação com tal perfil atrapalhou em seu luto "pois fazia me lembrar daquela pessoa". A partir dessa pergunta, o respondente começou a se engajar: disse que gostaria que alguém atualizasse seu perfil no caso do próprio falecimento - indicando ao menos uma ideia de que se tratava de um universal inevitável - e assinalou que gostaria de responder as perguntas novamente sobre um outro usuário falecido. Na página que se abriu, respondeu que este outro usuário falecido se tratava de um amigo de 56 anos e que sua interação com o perfil se deu através de "Choro e postagens".

Creio que seja possível inferir que o respondente teve um pouco de dificuldade para se localizar no questionário e que suas respostas concerniam a um mesmo falecido. O engajamento de uma criança pré-púbere não era esperado e é muito significativo que o garoto tenha respondido desejar que seu perfil continue depois do próprio falecimento; uma resposta paradoxal, afinal, ele apontou que o fato do perfil de seu amigo permanecer publicado atrapalhou em seu luto.

Em termos gerais, parece haver uma relação de causalidade entre a ideia de manutenção ou não da página do Facebook depois da própria morte e a idade dos usuários respondentes. 
Na Figura 4, o gráfico representa como os dois extremos das idades têm pretensões diferentes sobre o destino do próprio perfil depois de suas mortes. Se na faixa de 60 anos ou mais, existe uma restrição em manter o perfil publicado - seja funcionando, atualizado ou enquanto página memorial - o que corresponde à $60 \%$ dos mais velhos que responderam tal questão, na faixa até os 20 anos, apenas $30 \%$ gostariam de ver seu perfil deletado da rede. Esse dado pode servir como um indício de uma relação diferente, talvez mais naturalizada, dos denominados nativos digitais, com os WRS's.

\section{Figura 4}

\section{Comparação entre os mais novos e os mais velhos referente à manutenção ou exclusão do perfil depois da própria morte.}

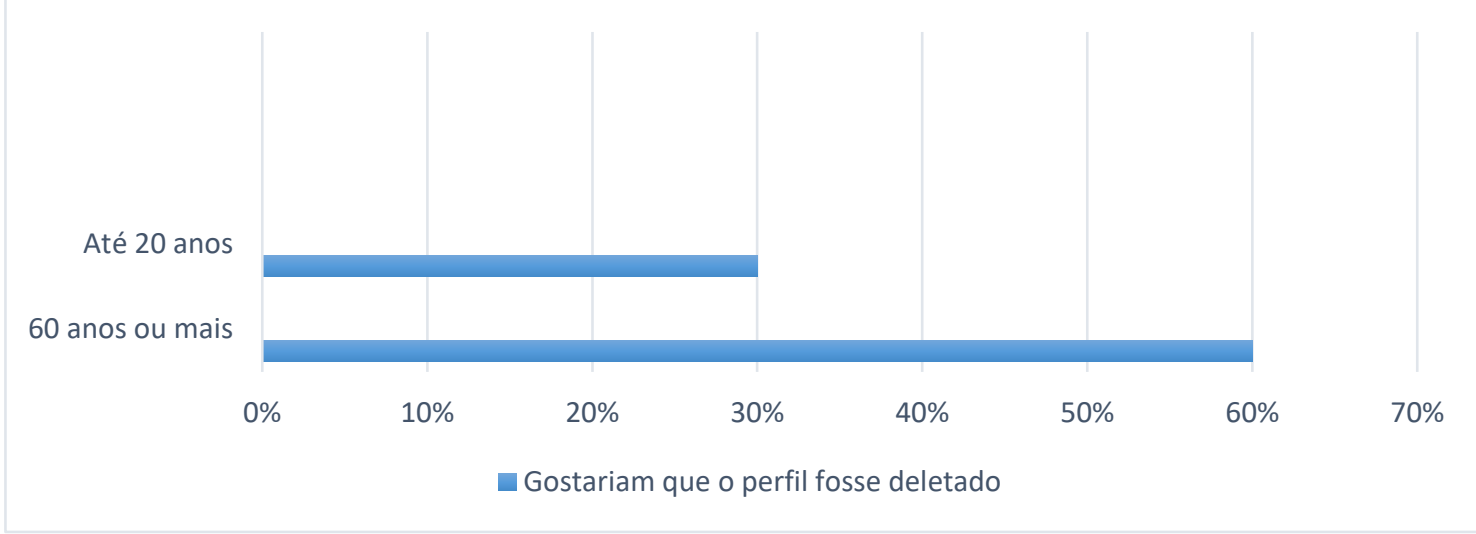

\section{Depois da própria morte, o que fazer com o perfil?}

Na Figura 5, podemos constatar que dos 145 respondentes que marcaram essa resposta, 61 $(42,07 \%)$ apontaram que, no caso da própria morte, gostariam que o perfil fosse definitivamente desabilitado. Ou seja, excluído da rede. Logo após, 42 (28.97\%) deles marcaram que gostariam que a página se transformasse em um memorial no qual os parentes poderiam deixar condolências, porém o perfil não poderia mais ser atualizado ou editado. Sendo assim, uma parte significativa dos respondentes não gostariam que seu Facebook pudesse continuar a ser 
atualizado e circular na rede. Em contrapartida, isso significa que uma quantidade considerável - quase $30 \%$ - prefeririam que seus perfis tivessem algum tipo de continuidade.

Figura 5

Q18 Se você viesse a falecer, o que gostaria que acontecesse com seu perfil do Facebook?

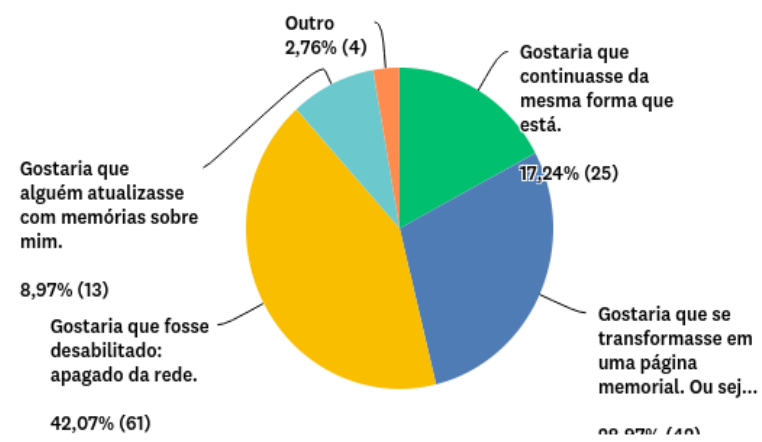

Na pesquisa de Brubaker et al. (2013), nenhum dos entrevistados demonstrou interesse em colocar páginas dos amigos como memorial. O Facebook, em sua página de configurações, permite ao usuário designar um herdeiro digital: atrelar o próprio perfil a um outro perfil para que seus dados sejam transferidos automaticamente depois do falecimento do usuário.

Essa é uma questão relevante que perpassa até discussões legais. O conceito de legado digital provém dessa questão: quem teria direitos de ficar com o conjunto de informações que o usuário reúne no ciberespaço. De acordo com a Associação Legado Digital- que oferece documentos e amparo legal para que a pessoa forje um testamento designando o herdeiro de seu legado e também treinamento e pesquisa para profissionais que trabalhem na área, sobretudo no campo do direito - o conceito pode ser definido assim:

"O legado digital é a informação digital que está disponível sobre alguém depois de sua morte. O legado digital de alguém também é formado pela informação que ele deixou online. Isso inclui qualquer website, blog sobre a pessoa, seus perfis em redes sociais, fotos, vídeos, perfis de jogos e interações que eles tiveram online" (Digital Legacy Association, 2018).

É bem provável que com a emersão de inúmeros perfis comerciais atrelados aos perfis nos WRS's, tal questão seja central na preocupação sobre a manutenção dos perfis.

Se aplicamos um recorte de gênero em relação ao tema, as variações são bem pequenas e se mantém na preponderância de apagar os perfis da rede ou transformá-los em página memorial. 
Tal dado é interessante por explicitar certa tendência em desejar que o próprio perfil não continue circulando nas redes, podendo ser atualizado, editado, enviar ou receber mensagens.

\section{O Facebook enquanto meio de divulgação de um falecimento: os anúncios fúnebres}

Uma das emersões mais interessantes que se explicitaram nas respostas fora a relação do Facebook enquanto meio de divulgação de um óbito. Se combinarmos as respostas que se referem a essa modalidade - os que souberam do falecimento de alguém "Pelo próprio Facebook, através de alguém" (27,54\%) e "Por uma publicação ou atualização do Facebook" $(14,71 \%)$ - chegamos a importância de 42,25\% dos respondentes. Assim, 42,25\% dos respondentes do questionário foram informados de uma morte a partir do Facebook.

Figura 6

Q9 Como você ficou sabendo do falecimento desta pessoa?

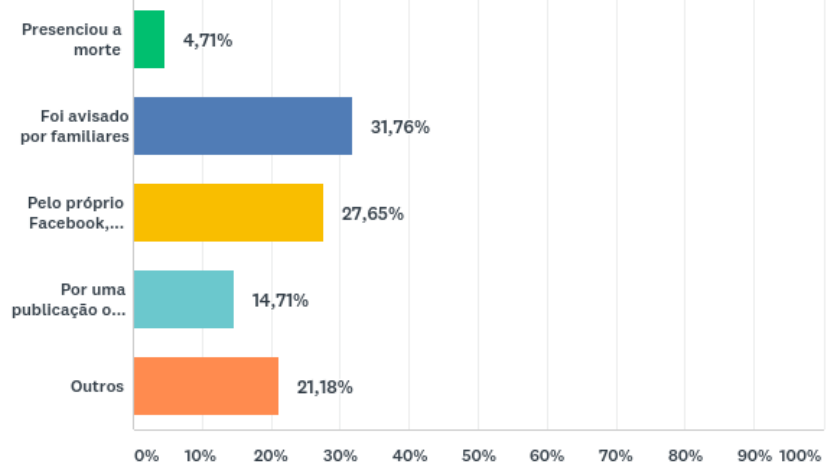

Essa tendência se seguiu entre os 16 usuários que se dispuseram a responder sobre outros perfis de falecidos na pesquisa ${ }^{12}$ : dos 16 respondentes, 9 (56,25\%) ficaram sabendo do falecimento pelo próprio Facebook ou por uma publicação fúnebre/atualização no Facebook.

Podemos pensar, a partir desses dados, em uma função social própria dos WRS's. As notas de falecimento e os obituários são costumeiramente associados aos jornais de língua inglesa e se constituem em um gênero literário. De acordo com Vieira (2017):

"Essas pequenas biografias, urdidas segundo estruturas ficcionais (ainda que o estatuto não perca sua relação certificatória com o discurso da imprensa), são lidas por motivos que vão do rito fúnebre escandido por estímulos do

\footnotetext{
${ }^{12} \mathrm{Na}$ segunda página que se abria quando o respondente desejava falar sobre um segundo falecido, no questionário.
} 
presente ao esforço de memória coletiva, sem abandonar o simples prazer da leitura, seu apelo estético [...]"

Podemos realizar aproximações e essa intersecção pode inspirar novas pesquisas, sobretudo em áreas da literatura. O que nos interessa é a função social do informe do falecimento. Na pesquisa de Brubaker et al. (2013), algo que os entrevistados narram enquanto estranhamento, é justamente quando pretendem conversar ou parabenizar um outro perfil em data comemorativa e realizam que seu proprietário faleceu. Se a rede/grupo no qual o usuário está inserido é relativamente grande - muitos perfis contam com 3, 4 mil amigos - saber se todos estão vivos ou ser informado sobre todos os falecimentos é quase impossível.

Porém, nesse sentido, por se tratar de um dos meios de comunicação mais usados atualmente, podemos intuitivamente pensar que seu uso enquanto obituário, ou seja, um veículo de registros necrológicos, sobretudo os mais recentes, é uma consequência. Mas a questão dos anúncios fúnebre é peculiar no Brasil e perpassa uma esfera psicológica também.

O Professor Witter (1983), ao fazer uma belíssima análise dos anúncios fúnebres nos jornais brasileiros entre 1920 e 1940, destaca a função de tais manifestações: tais anúncios serviriam para "externar o significado da morte, especialmente para a família" (Id. p. 86) e "[...] manter, através da solidariedade entre os que ficaram, um conforto e um calor humano que acabam por manter os laços do grupo". Essa é uma função muito interessante e provavelmente análoga a ideia de reunir em um anúncio fúnebre digital o grupo social do qual o falecido participava.

A partir dessa analogia, irei derivar para duas questões: a primeira, sobre a função dos grupos depois da morte de algum usuário e como isso se evidencia na pesquisa de Brubaker et al. (2013) e reflete sobretudo o rito norte-americano e se no Brasil existem manifestações equivalentes. A segunda, em relação à uma possível dimensão asséptica do anúncio fúnebre digital, o que desobrigaria os enlutados e aquele que presta informações a lidar com a reação direta dos familiares e do grupo social do morto.

Na pesquisa de Brubaker et al. (2013, p. 12), os pesquisadores se depararam com uma prática comum aos enlutados: a criação de espécies de "grupos de apoio" mantidos pelo grupo social do morto depois da morte para trocarem mensagens e mídia que diziam respeito a vida daquele que faleceu. Em minha pesquisa, não encontrei grupos no Facebook com essa função. Porém, outras manifestações sobre os perfis de falecidos chamam bastante a atenção, como a página Falecidos do face (2018) que conta com quase 30 mil seguidores e serve exclusivamente para compartilhar perfis de falecidos - quase anônimos - e comentar um pouco sobre a história de cada um. 
Os usuários interagem bastante com as postagens e geralmente demonstram muita tristeza pelo desconhecido que falecera e que teve seu perfil publicado na página. $\mathrm{O}$ anúncio da morte de um motorista, por exemplo, gera curiosidade nos usuários que entram em seu perfil e descrevem suas opiniões "Nossa, a frase do perfil dele é premonitória! Uma pena, aparentava ser um cidadão se bem, trabalhador...Que Deus tenha piedade de sua alma”.

Além disso, encontramos inúmeros casos nos quais os comentadores revelam um certo "voyeurismo" em relação a morte de um desconhecido: ao perpassar os olhos pelo perfil buscando traços que revelem um algo sobre aquele morto, é comum se deparar com discussões sobre a causa mortis de alguém, sobretudo em casos que geram muita comoção.

Uma notícia de jornal do interior é compartilhada junto com o perfil da falecida: uma jovem de 19 anos que provavelmente suicidou. Um primeiro comentador sugere matéria tendenciosa: "Tá parecendo mais ter sido morte súbita. Nem no face do namorado vi nada que indicasse suicídio, como sugere a matéria", e é repelido por um outro que indicam uma postagem do tal namorado sobre o fato: "Veja os comentários dessa postagem do namorado dela, lá ele fala que ela cometeu suicídio. Senhor te pedi para segurar a mão dela e guia lá, obrigado, mas não te agradeço por tê-la levado pra vc... Mas sendo assim cuide dela pois ela é peça única...”. Os outros comentadores encontram então a postagem do namorado da falecida e entram em consenso sobre seu suicídio.

Além do efeito da curiosidade, a comoção deriva para uma espécie de identificação que se converte em relato próprio:

"Eu já tive depressão pesada mesmo, não pensava em outra coisa além de
morrer. Fazia vários planos com esse objetivo e, uma coisa eu afirmo: não
existe prevenção, desabafo, Conselho, religião. Nada que tire essa ideia da
cabeça de uma pessoa doente. Chega a ser uma obsessão porque você não vê
futuro, não vê alegria, não tem esperança. Só um buraco negro que te engole
cada dia mais. Eu tomo medicamentos pra me manter bem, mas tenho muito
medo de parar e sentir toda essa dor na alma novamente”. Poderíamos agrupar várias categorias para pensar tais comentários. Se os efeitos de curiosidade e identificação são comuns em casos de suicídio, casos de morte por violência evocam intensa raiva em relação aos executores. Em um caso de homicídio de um garoto de 19 anos, os comentários são efusivos: "Raça de praga demônios que morram da pior maneira !!!”, o que se revela mais intenso ainda em relação a um padrasto que abusara da enteada e a matara: "Esse monstro não merece viver ...”, “Meu Deus, Que dor ler isso!!! Que ódio”, “E ainda tem gente que é contra a pena de morte...". 
Cada modalidade de morte evoca determinados sentimentos. O que existe em comum entre os comentadores, tanto no caso de morte por acidente - geralmente automotivo - quanto no caso de morte por violência, é uma espécie de narrativa que tenta definir um cálculo, uma exata causalidade de eventos que culminaram na morte. A curiosidade, a identificação, o "expurgo" da raiva, parecem aparecer sob uma função bem precisa: como se, ao se deparar com o anúncio fúnebre do outro, o comentador precisa exercer determinado cálculo para que o mesmo não aconteça consigo mesmo. Como exposto nos casos retro referidos, determinar a sequência de eventos ou a causa com precisão, parece apaziguar os efeitos dos afetos daqueles que fazem parte da comunidade.

Essa ideia endossa a tese de que a morte, na contemporaneidade, passa a ser encarada como um acidente, não como algo necessário. Mais que interdito, a ideia da morte é tão alheia para alguns usuários que parece que a página Falecidos do Face e incontáveis similares, exercem uma verdadeira função social no que se refere a informar sobre a morte. Um dos usuários que a recomenda comenta:

"É incrivel como o número de mortes diárias passa tão despercebido diante de nossos olhos, às vezes achamos que grande parte destas pessoas que morrem são apenas aquelas noticiadas em jornais televisionados que a gente vê e acredita ser só aquela quantidade $x$, mas ao olhar esta página eu pude ter noção de que não é bem assim, chega a ser algo inacreditável. É lamentável a frequência de como isso acontece, infelizmente."

Talvez um efeito do deslocamento do moribundo do meio social, da supressão de quaisquer narrativas que se referem a morte e ao morto, a "morte limpa", hospitalar. O despretensioso comentário anuncia a lida contemporânea com a morte: "É lamentável a frequência de como isso acontece, infelizmente".

Sobre os anúncios fúnebres nos jornais, Witter (1983, p. 88) aponta um entrelace entre padronização e a impessoalidade para destacar a dimensão asséptica em relação ao anúncio, que devemos então "compreendê-lo como parte integrante de um ritual, quase asséptico, que desobriga o próprio grupo familiar da tarefa árdua e dolorosa de comunicar [...] o falecimento do "morto querido"”. Em contrapartida, os anúncios fúnebres realizados no Facebook não costumam ser padronizados; pelo contrário, costumeiramente são acompanhados de fotografias e de alguma narrativa bem pessoal, em nome próprio ou familiar.

Um pequeno recorte historiográfico para nos situar em relação ao que Ferrer (2018, p. 21) chamou de "linguagem da morte": 
"A viagem começa com os primeiros hieróglifos das tumbas antigas, continua nos epitáfios gregos e romanos, nos discursos póstumos dedicados aos heróis e imperadores, assim como a lista de 'últimas palavras' atribuída aos protagonistas e homens da história tempo. Com o tempo, a Igreja Católica passou a generalizar certas expressões e frases para homenagear os mortos, difundindo, nos séculos antigos, inúmeros textos escatológicos e manuais sobre a 'arte de morrer'. Com a difusão da impressão na Renascença, a linguagem da morte seria enriquecida com o aparecimento dos obituários de convite e as participações do óbito, as crônicas dos ritos funerários da realeza, canções populares, os poemas post mortem e a literatura necrófila, que alcançaria seu maior esplendor entre os séculos XVIII e XIX. No século XX, o tema da morte deixaria de ser uma obsessão literária e gradualmente se aproximaria da mídia jornalística, na forma de obituários e obituários.

No questionário, algumas das respostas que concerniam à pergunta 11 - "Qual foi a interação que você teve com o perfil do usuário após o falecimento?" - se referiam precisamente a questão. Os exemplos contradizem a ideia de um anúncio fúnebre asséptico e impessoal: por exemplo, uma mulher de 42 anos, em São Paulo, que perdeu o pai, entrou em seu perfil para fazer o anuncio: "Meu pai que faleceu. Após alguns dias, nós da família nos lembramos de avisar os amigos dele via Facebook. Coube a mim passar a informação de morte. Também respondi alguns recados". Essa respondente evidencia uma relação clara e que considera que fora positiva com a função dos WRS's enquanto disseminadores de informação do falecimento de alguém. Ela responde que a existência do perfil a ajudara no processo de luto:

"Acredito ter ajudado. Não tenho muita certeza. Creio que receber notícias e fotos de alguns amigos dele me ajudou a preencher um pouco do vazio. Além disto, fizemos o velório muito rapidamente, poucos conseguiram ir. Ver os retornos foi como se mais gente tivesse ido 'se despedir' (entre aspas, pq acredito que só haja despedidas quando existe vida)".

Em sua experiência, considera a informação do falecimento de alguém muito importante: “[...] Saber que a pessoa morreu, e não apenas desativou o Facebook, torna-se importante pelo peso emocional envolvido.". É bem provável que em casos de amizades considerados não tão íntimos, o informe da morte se tratasse sempre de algo dotado de certo anacronismo. Isso empresta à ideia de intimidade também um valor relacional, relativo àqueles que a família ou o círculo social mais próximos consideram fundamental para participar do rito fúnebre.

Todos os 3 participantes que narraram interagir com o perfil do falecido para realizar o anúncio de morte tinham relação direta e de primeiro grau com os falecidos: duas perderam a mãe e uma o pai.

A segunda respondente, de 30 anos, que também perdera a própria mãe relata algo parecido, "mandei mensagem no timeline dela para que as pessoas pudessem saber do seu falecimento e causa. Além disso, muitas pessoas postaram alguma foto que tinha dela e fui salvando quando 
aparecia.". A respondente considera que a existência de tal perfil ajudou muito em seu processo de luto justamente por conseguir acessar os contatos com os quais a mãe nutria um laço.

Porém, a experiência da terceira respondente que utilizou o perfil para um anúncio fúnebre e que perdera a própria mãe e, portanto, gerência sua conta-memorial, relata que a existência do perfil atrapalhou seu processo de luto: "A sensação é que a pessoa ainda continuava ali do outro lado da tela". Ainda assim, também o utilizou para informar sobre a morte da mãe aos seus contatos.

Percebemos que a relação com a morte no Facebook - apesar de intuitivamente pensarmos que pode se tratar de algo muito impessoal e asséptico - se revela bastante pessoal e funcional enquanto função de informe ao meio social, sobretudo àqueles que, não sendo tão íntimos ao círculo social do falecido, poderiam permanecer alheios à tal informação em outras circunstâncias. Além disso, tais anúncios - diferentemente dos jornais - são imbuídos de mensagens particulares, pessoais e íntimas sobre a relação daquele que escreve com o falecido, o que sugere uma passagem dos jornais e dos cemitérios virtuais aos WRS's enquanto espaços privilegiados para escrever sobre e para o morto, e para posteridade, o que Ferrer (2018) chamou de "linguagem da morte".

\section{Modalidades de interação com o usuário falecido}

Na Figura 7, podemos perceber que a maioria dos respondentes tiveram alguma interação com o perfil do usuário após o falecimento, o que corresponde à 67,05\% (116) dos 173 respondentes. Após tal questão, o respondente foi levado a escrever, em uma caixa de texto, sobre a modalidade de interação com o perfil do usuário falecido. 
Figura 7

Q10 Você teve alguma interação com o perfil do usuário após o falecimento? Exemplos: leu mensagens enviadas, participou de grupos de apoio, entrou em contato com amigos através do perfil ou escreveu mensagens para familiares ou para o próprio morto?

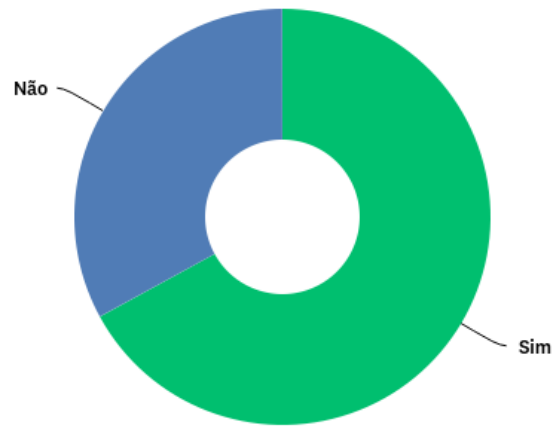

Notamos uma certa preponderância nas respostas que apontam para uma interação através do olhar, 65 deles $(59,09 \%)$ responderam que entraram no perfil do usuário falecido para ler mensagens deixadas por familiares e amigos do morto, para ler mensagens trocadas entre eles mesmos ou simplesmente para visualizar fotos antigas e o perfil do falecido.

Essa constatação endossa a hipótese retro referida de um certo voyeurismo da morte nos WRS's. Algumas respostas apontam para uma necessidade de interação a partir disso: "Li as mensagens que as pessoas deixaram em condolências. Também comentei sobre a pessoa falecida em uma publicação pública, já que a pessoa foi minha chefe direta e teve sempre uma postura ética, quis publicamente ressaltar isso".

Nesse sentido, das condolências públicas, percebemos um certo cuidado em relação aos outros usuários que em algum momento poderão visitar os perfis, algo que já não demarca o ritual do luto em um tempo cronológico. Na verdade, o Facebook, por se tratar de um meio de comunicação assíncrona, mas que possibilita a circularidade dos perfis em qualquer tempo, parece convidar para que os usuários emitam, definam, caracterizem, "imaginarizem” o perfil do falecido da forma que consideram ideal: "Verifiquei as mensagens póstumas e deixei uma mensagem para que o filho dela que é bebê, possa ver futuramente e saber o quanto ela foi querida. "Mais do que uma mensagem enviada para o futuro, o que já é muito significativo, a respondente se preocupa com o "saber o quanto ela foi querida", com a imagem que a falecida possa passar para o filho no futuro. 
Além de poder operar, editar o perfil, percorrê-lo com o olhar também parece exercer uma determinada função, na esteira também de uma das hipóteses retro referidas, a de tentar construir um saber sobre a morte: "Li mensagens para entender melhor o que aconteceu".

Figura 8

Q11 Qual foi a interação que você teve com o perfil do usuário após o falecimento?

$$
\begin{aligned}
& \text { perfil pessoa para facebook amigos } \text { Ler mensagens } \text { Li mensagens mensagem }_{\text {que }} \text { dele }_{\text {ver }} \\
& \text { mensagens } \text { Ler fotos }_{\text {em }} \mathrm{Li}_{\text {vi os da }}
\end{aligned}
$$

A figura 8 se trata de uma nuvem de palavras: uma figura que revela as palavras de maior incidência nas respostas. Sua construção desvela a preponderância da questão do olhar nos respondentes.

Das modalidades de interação com os usuários falecidos, destaquei seis categorias:

Figura 9

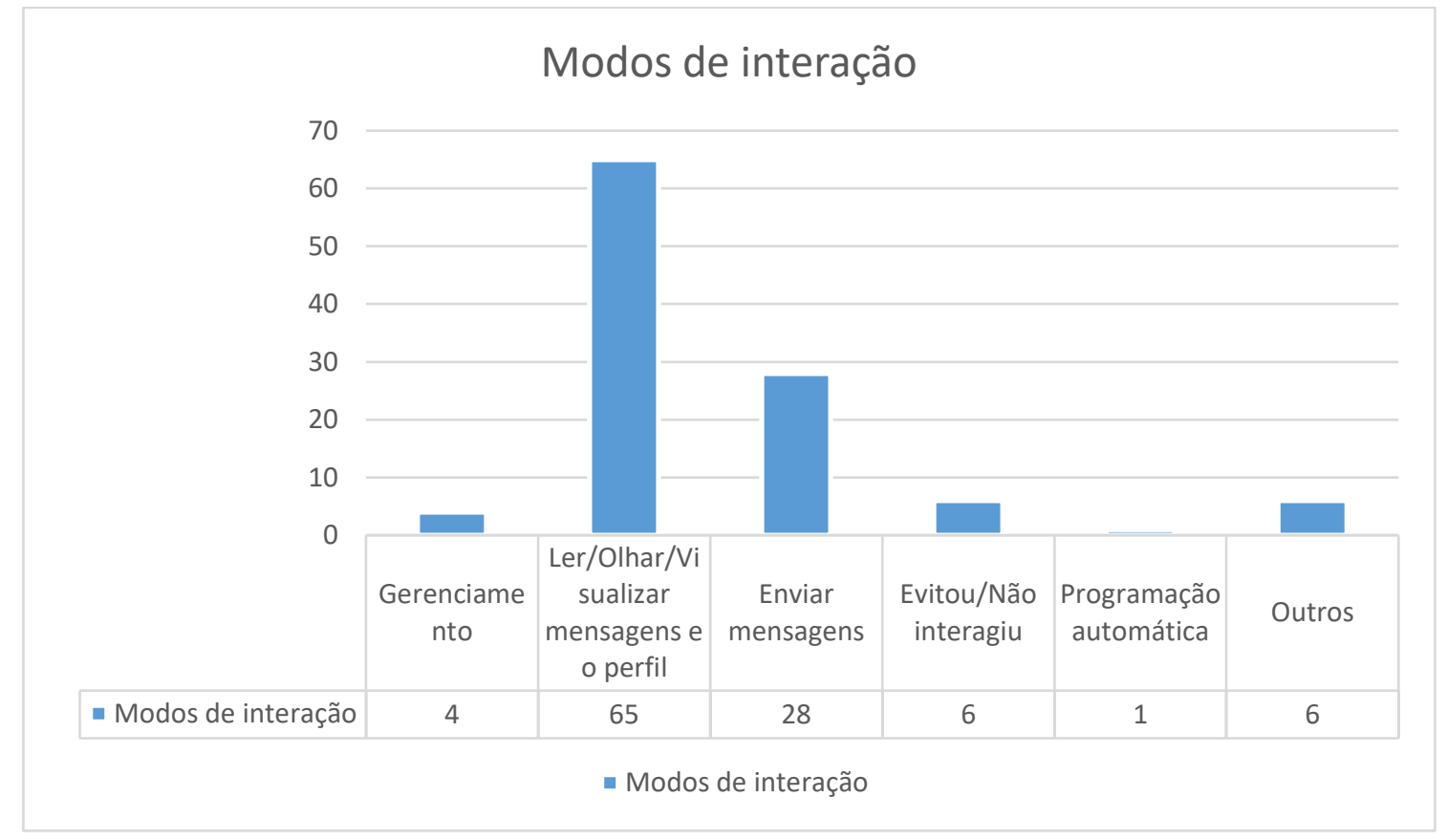

Além da interação que concerne ao olhar, em segundo lugar encontramos uma grande incidência de respondentes que enviaram mensagens ao perfil do falecido: diretamente ao morto ou para a família do mesmo. Essa modalidade entra na categoria descrita por Jed Brubaker e Hayes (2011 apud Brubaker et al., 2013, p. 12), em pesquisa realizada a partir do MySpace, 
aonde os autores encontraram um forte padrão de mensagens postadas nos perfis dos mortos diretamente ao morto, e não em direção à família, como fora comentado em capítulo anterior.

Em contrapartida, no questionário, percebemos uma tendência bem distribuída da direção das mensagens: 11 das 28 respostas apontam para mensagens em direção à família, como "escrevi mensagens de apoio à família e aos amigos do falecido" e "mensagem visando os familiares, dando força e pêsames".

7 das respostas sugerem uma interação direta com o falecido, como "mandei mensagens contando sobre a vida", "mandava mensagens de saudade" e "saudações no aniversário". Essas respostas são muito interessantes e faz com que pensemos na relação de uma mensagem diretamente enviada ao falecido, o que endossa a pesquisa de Brubaker e Hayes (Id. Ibid., 2013).

As outras 10 respostas são indeterminadas, sem um destinatário específico, ao menos aparentemente: como "dizer o quanto lamentava a perda do amigo e de como faria falta a todos nós que o conhecíamos" e "enviar uma mensagem com oração".

Voltando às modalidades de interação, 6 respondentes disseram que não houve interação, apesar de terem demarcado a resposta anterior e 1 deles demarcou que preferia não entrar no perfil do falecido pois ele evocava saudades.

4 dos respondentes descreveram uma modalidade de interação que apontava para o gerenciamento do perfil do falecido. Esses tiveram um luto direto de um familiar importante: duas se referem a morte da mãe, uma do pai e outro de uma tia. As respostas concernem a função de informe para gerenciar o perfil do falecido. Essa modalidade fica bem evidente quando comentei sobre a função de divulgação de um falecimento: "Meu pai que faleceu. Após alguns dias, nós da família nos lembramos de avisar os amigos dele via Facebook. Coube a mim passar a informação de morte. Também respondi alguns recados”.

1 dos respondentes demarcou que fora a chamada de aniversário do Facebook que fez com que o mesmo interagisse com o perfil do falecido: "o face me avisou do aniversário dele e tive curiosidade em saber quem daria parabéns automaticamente, sem saber que ele já havia falecido”. Apesar de ser apenas uma resposta que indique a questão da programação automática, que faz com que os perfis insistam, circulem, achei interessante elencar enquanto categoria por representar algo análogo ao que Brubaker et al. (2013) chamaram de tumbas interativas digitais: a possibilidade de o perfil continuar a circular nas redes, no mundo dos vivos, a partir da programação. Tal ideia é atrelada aos usuários que se deparam com a morte 
enquanto um encontro inesperado nos WRS's, uma morte com a qual o usuário que está navegando em suas redes não esperaria se deparar.

Por último, 6 dos respondentes estão em uma modalidade que chamei de outros, por não conseguir isolar por aproximação, analogia, ou porque descreveram de uma forma incompreensível, como simplesmente "triste" ou "através de amigos", ou então porque apresentaram algo não esperado para as respostas, como um respondente que escreveu: " $A$ mãe dele deu sequência no perfil dele. Curtindo as coisas que eu posto/postava ou compartilho/compartilhava.".

Essa resposta sugere algo singular e que não encontrei em nenhuma outra pesquisa: o fato de uma mãe dar sequência ao perfil do filho falecido e passar a interagir com seus amigos. Um ponto de atenção para pensarmos no luto dos filhos, inclusive na tese de Allouch sobre tal modalidade de luto enquanto paradigma no contemporâneo.

Na esteira do exemplo dessa mãe que continuou a utilizar o perfil de seu falecido, além de tais modalidades de interação, os respondentes também foram convidados a dizerem se alimentaram ou mantiveram algum perfil de pessoa falecida.

Um adendo: acho interessante destacar que as respostas extraídas de 16 respondentes que aceitaram falar sobre mais de um falecido seguiram a tendência dos dados sobre tais modalidades: 7 deles $(43,75 \%)$ responderam ter lido/olhado/visualizado os perfis, 4 deles interagiram enviando mensagens, 4 não tiveram interação e 1 respondeu apenas "triste".

\section{Atualizando/alimentando/sustentando os perfis dos falecidos}

Na Figura 10 nos deparamos com o fato de que 24 dos 166 respondentes da questão 12 afirmaram que "alimentaram" perfis de falecidos com algum conteúdo. Nas respostas, os

usuários descrevem que alimentaram os perfis com homenagens, textos e fotos; com preponderância de perfis de amigos. 
Figura 10

Q12 Você "alimentou" com conteúdos ou manteve o perfil de alguma pessoa falecida?

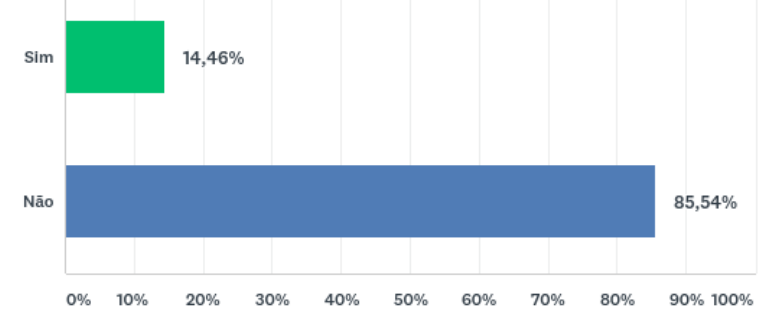

Desses, apenas 2 responderam que criaram perfis de falecidos. Tal pergunta fora formulada para pensarmos na questão da morte anacrônica: se existia a demanda por criações de perfis de mortes antigas, como parentes que já faleceram há anos ou até pessoas públicas. Na figura 11, podemos perceber que a demanda fora baixíssima nessa modalidade. Desses 2, apenas 1 respondeu: teve a ideia de criar um perfil de alguém falecido que fora uma figura histórica: “Apenas por ser uma personalidade importante de da história das ideias”.

Figura 11

Q14 Você criou o perfil de alguma pessoa falecida?

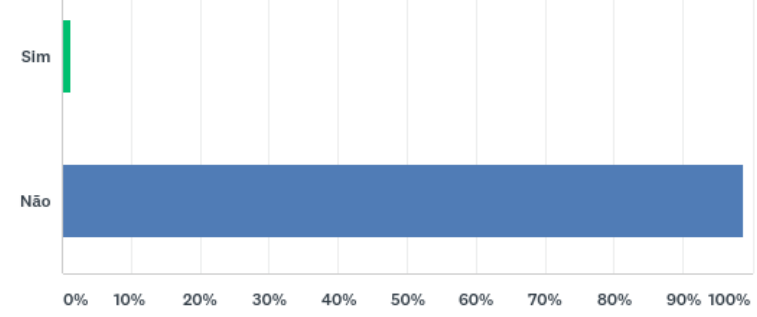

Reproduzir ou mimetizar famosos falecidos se trata de um fenômeno recorrente na cultura. Algumas dessas manifestações, por exemplo, "O Billbord Music Awards (edição de 2014) e o Coachella Fest (edição 2012), surpreenderam boa parte do público ao exibirem no palco performances encenadas por cantores já falecidos, como Michael Jackson (1958 - 2009) e Tupac Shakur (1971 - 1996), respectivamente” (Schivani et al., 2018). O que os organizadores fizeram foi oferecer ao público uma apresentação na qual pirâmides "holográficas" muito criveis se apresentavam passando-se pelos cantores. O efeito no público fora compartilhado no mundo todo e levantou debates sobre essa forma de interação. No Facebook, a prática de criar perfis de falecidos famosos é muito comum: de Tupac Shakur a Shakespeare, de Camus a 
Charles Dickens, inúmeras são as páginas que se propõem a compartilhar conteúdos, inclusive como se fosse em primeira pessoa, "em nome de".

\section{Interagir com os perfis de falecidos: uma experiência positiva ou negativa para o enlutado?}

A pergunta 16, creio que uma das mais importantes do questionário, pedia ao participante para indicar entre 5 alternativas de uma escala que ia do 1 (atrapalhou muito) ao 5 (ajudou muito), quando indagados sobre a influência do contato com o perfil do falecido no luto. Na Figura 12, podemos observar que a média ponderada das 150 respostas obtidas aponta para uma resposta que indica que o contato com o perfil do usuário falecido foi indiferente no processo de luto.

Figura 12

Q16 Pessoalmente, você acha que o contato com o perfil do usuário falecido no Facebook te ajudou ou atrapalhou no processo de luto pela morte de alguém que tinha/tem perfil no

Facebook? Entre 1 e 5, sendo que 1 quer dizer que atrapalhou e 5 que ajudou muito, sendo o número 3 que foi indiferente.

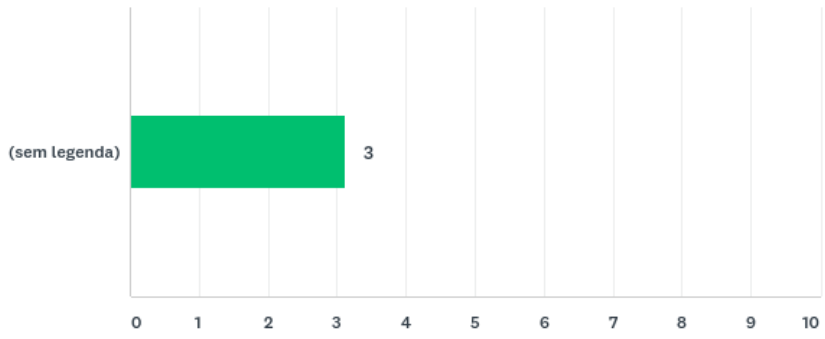

Essa média levou em conta a distribuição de respostas da seguinte forma: 6 (4\%) pessoas consideraram que tal contato atrapalhou muito, 19 (12,67\%) pessoas consideraram que o contato simplesmente atrapalhou, para $84(56 \%)$ dos respondentes, o contato foi indiferente, para $33(22 \%)$ o contato ajudou e para $8(5,33 \%)$ ajudou muito. Desse total, extraímos uma média ponderada de 3,2. A partir desse resultado, trabalhamos com a hipótese de que para a maioria das pessoas que responderam ao questionário, o contato com o perfil do usuário falecido no Facebook seria indiferente no processo de luto. 
Figura 13

Q16 Pessoalmente, você acha que o contato com o perfil do usuário falecido no Facebook te ajudou ou atrapalhou no processo de luto pela morte de alguém que tinha/tem perfil no Facebook? Entre 1 e 5, sendo que 1 quer dizer que atrapalhou e 5 que ajudou muito, sendo o número 3 que foi indiferente.

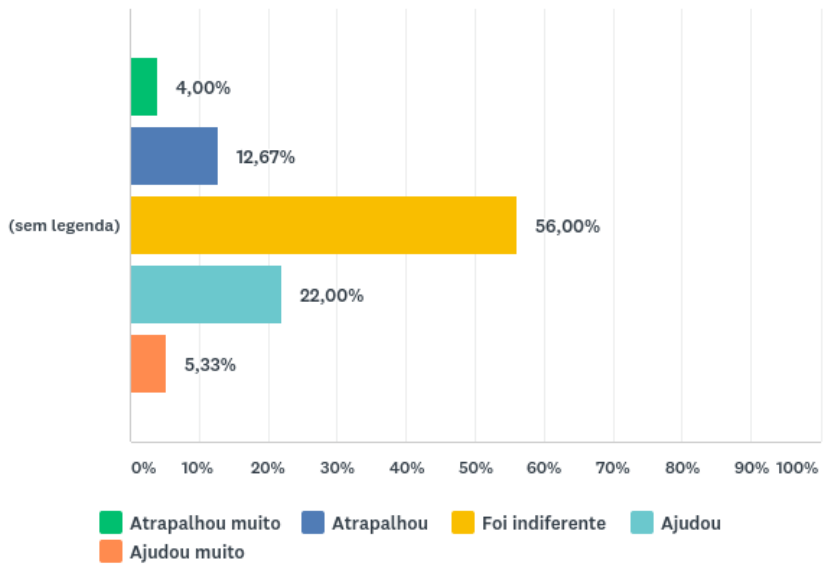

Porém, quando nos deparamos com os dados distribuídos, percebemos que para 41 respondentes a experiência foi positiva e ajudou ou ajudou muito, o que corresponde à 27,33\% dos respondentes. Por outro lado, para 25 pessoas, tal experiência fora negativa e atrapalhou ou atrapalhou muito o processo de luto, o que corresponde à $16,67 \%$ dos respondentes dessa questão.

Percebemos então que o número de respondentes que tiveram uma experiência positiva no contato com usuários falecidos supera em pouco mais de $10 \%$ o número de respondentes que tiveram uma experiência negativa: $27,33 \%$ contra $16,67 \%$.

O respondente que marcava essa pergunta era então convidado na posterior a contar um pouco sobre os motivos da resposta, as razões por atrapalhar, ajudar ou ser indiferente. Dos 146 usuários que responderam, realizei uma divisão entre três categorias de experiência de luto narradas: positiva, negativa ou indiferente. $\mathrm{O}$ texto apresenta algumas questões muito importantes para pensarmos nos dados apresentados. Ao elencar e dividir as respostas nessas categorias, percebemos pequenos desvios. 


\section{Você poderia nos contar porque ajudou, atrapalhou ou foi indiferente?}

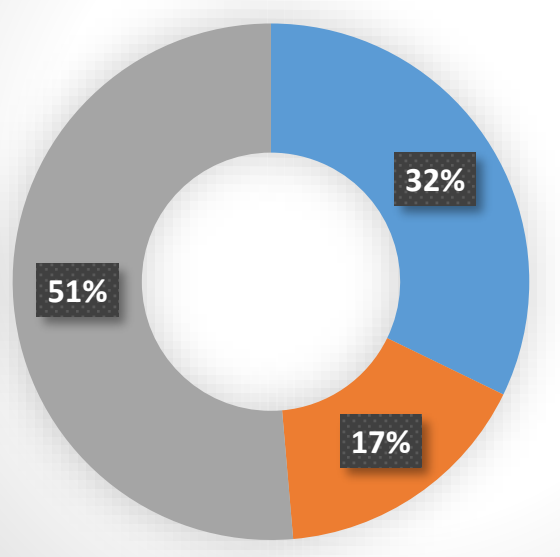

Positiva

Negativa

- Indiferente

Na Figura 14, dos 146 respondentes da Q17, percebemos que a divisão entre três categorias implicou em 75 que demarcaram ter sido indiferente, 24 que tiveram uma experiência negativa e 47 positiva em relação à interação com os perfis de usuários falecidos.

Porém, algo que concerne a uma análise dos textos depois de divididos em categorias muda nossa percepção dos dados: dos 75 que demarcaram ter sido indiferente, 21 responderam ser indiferente justamente por terem uma relação muito afastada do falecido: "Indiferente, pois não tinha contato com a falecida", "Foi indiferente porque nunca alguém muito próximo faleceu e continuou tendo perfil no Facebook", "Pois não conhecia muito bem a pessoa", "Porque a pessoa não era tão próxima. Porém estes dias vi que o perfil continuava ativo e achei estranho.", "Indiferente porque eu era distante da pessoa”, etc. Ao menos 2 dos indiferentes apontaram como causa o fato de usarem pouco o Facebook: "Não acesso muito o Facebook”, “Não visito perfis.”.

Devemos levar em conta tal consideração antes de apontar a preponderância de uma indiferença em relação aos perfis de falecidos. Afinal, excluindo-se essas duas subcategorias, da indiferença por falta de contato ou proximidade ou por não usar tanto o Facebook, chegamos a um número muito aproximado dos usuários que relatam ter tido uma experiência positiva de luto em relação aos perfis de falecidos. Além disso, respostas que demarcaram algo que seria realmente da ordem de uma indiferença, como "o fato de postar uma foto nossa juntos não melhorou meu 
ânimo nem compensou a perda", podem ser interpretadas como uma espécie de tentativa de suplência não realizada, frustrante. Dessa forma, não exatamente uma indiferença em relação ao perfil do falecido, mas uma falta de "compensação" enquanto instrumento para aliviar o luto. Essa modalidade emergiu bastante nas respostas entre os indiferentes: " $n \tilde{a} o$ fez diferença, as lembranças que o Facebook traz não traria a pessoa de volta e apenas mais saudades”. Nesse caso, por exemplo, poderíamos inferir que o respondente experimentou algo que ele consideraria negativo, em evocar "mais saudades". Outros também apontam para uma suplência bem-sucedida, como uma espécie de arquivo: "Foi só uma forma de aliviar a dor da perda", o que passa longe de uma indiferença.

Ao navegar nas respostas, procurei então a precisão: relatos que possam ser interpretados como indiferença: "o fato dela ter um perfil no Facebook não aumentou nem diminuiu o sentimento de luto. Era uma tia querida e o apoio e a proximidade da família foi o suficiente para o processo", "Porque a partir do momento que sei que está pessoa não está mais entre nós, para mim não faz sentido se quer pesquisar pela pessoa no Facebook”, "Luto é um processo humano e interpessoal, não vejo como a relação virtual possa ajudar ou atrapalhar tal sentimento”.

Pouquíssimas são as respostas com esse grau de precisão: a maioria corresponde ou a uma certa indiferença em relação ao próprio falecido, ou indiferença em relação ao que o respondente concebe como certa "função" dos perfis, ou respostas bem inconclusivas: "Sem comentários", "Não fiz", "Foi indiferente, apenas curioso.". Alguns, entre os indiferentes, também consideraram os perfis enquanto função de álbum fotográfico: "Indiferente pois eu só via o Facebook dele como um álbum de fotos com boas lembranças", "Foi indiferente como um álbum de fotos para lembrar das pessoas importantes em nossa vida”.

Ou seja, apesar de emergirem algumas questões interessantes, essa categoria demonstra um grau alto de imprecisão entre os que a demarcaram - sobretudo em respostas que desvelam algum grau de impacto positivo ou negativo na experiência, alguma diferença. Porém, se fizéssemos uma reordenação do gráfico a partir de uma interpretação da experiência dos respondentes, creio que exigiria escolhas demasiadamente arbitrárias, o que envolveria inferir que o que o respondente gostaria de responder não é exatamente o que decidiu anotar. Sendo assim, creio ser mais importante examinarmos o que entre aqueles que demarcaram uma experiência positiva ou negativa explicitaram.

\section{Experiências negativas a partir do contato com perfis de usuários falecidos}


Comecemos então por aqueles que disseram ter experimentado uma experiência negativa em tal lida com os perfis de usuários falecidos. De acordo com os relatos, decidi elencar tais experiências em quatro categorias: evocação de lembranças, incômodos morais, testemunho de sofrimento e tecno-imortalidade. Dois dos comentários deixei fora de tal divisão: um apenas comentou "porque sim" e outro "triste".

Figura 15

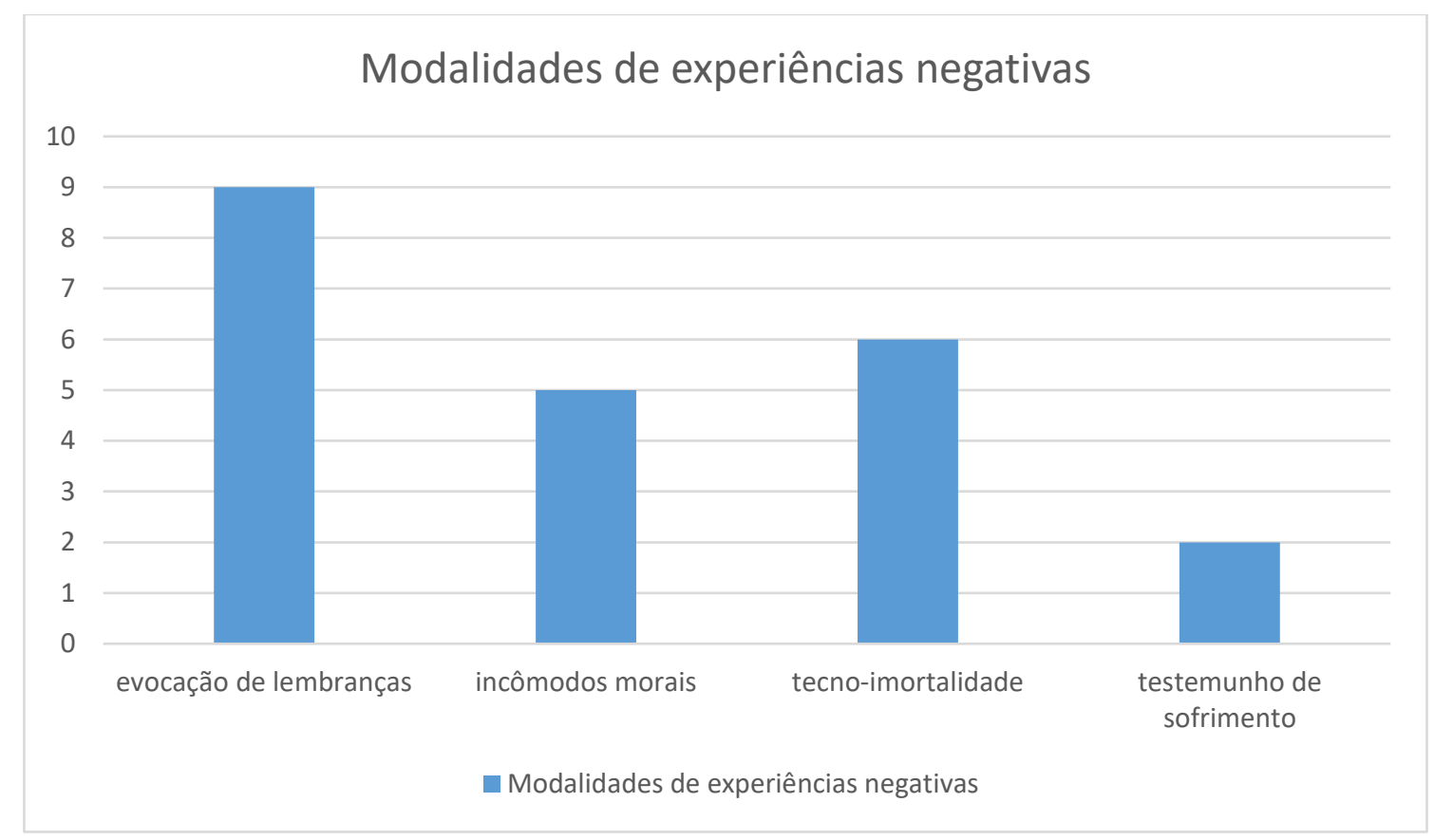

Na Figura 15 concebemos a distribuição das respostas entre as 4 categorias. Os primeiros encontraram na evocação de lembranças oferecida pelo Facebook uma forma de sofrimento, uma espécie de insistência de aparição dos perfis de falecidos. O fato de evocar a lembrança lhes causa incômodo: "Porque a lembrança nos faz sentir dor", "não conseguia esquecer", “É ruim ficar observando uma pessoa que era próxima. Traz sentimento de tristeza e saudade”. É interessante como o respondente se refere ao perfil enquanto pessoa, "ficar observando uma pessoa [...]”. Também encontramos exemplo de arrependimento que a memória pode evocar no enlutado: "Atrapalhou por que lembramos dos momentos que vivemos com essa pessoa, e o que poderíamos ter feito com ela antes da morte chegar!’. Essa descrição dá um sentido muito singular à ideia de arquivo vivo, que insiste e interage.

Em uma das descrições, a respondente narra a sensação que lhe atravessa ao se deparar com os pais "movimentando" o perfil de um falecido: "É estranho ver movimentado a página... os pais postaram fotos do falecido em alguns momentos. isso era particularmente dolorido, pois me 
fazia lembrar da perda em um momento que não estava preparada.”. Em tal passagem, fica evidenciada uma lida com a morte enquanto ruptura, a morte de alguém mais novo, considerada "antinatural", e o "movimento" que os pais realizam quase enquanto "suplência", ao colocar o perfil do filho para se "movimentar" na rede social.

A segunda categoria que demarquei se refere aos incômodos morais relatados por respondentes. Um deles se refere aos que "marcam" o perfil do falecido em postagens e considera isso um desrespeito aos familiares: "acho desrespeitoso com familiares quando a pessoa falecida é marcada em postagens. Tenho a sensação que o luto é constantemente reativado". De fato, se o perfil do falecido não for convertido em pagina memorial, tal perfil pode continuar a ser marcado em postagens de amigos. Tal modalidade pode apresentar para outros usuários aquilo que Brubaker et al. denominaram "encontros inesperados". Outro usuário conta o quanto ficara enraivecido por perceber que os amigos de um falecido que tivera se suicidado se compadeciam e ofereciam uma ajuda fora do tempo: "O falecido se suicidou e as mensagens eram de pessoas prestando ajuda após o ocorrido. O que me deixou com raiva”. Um terceiro usuário aponta para a questão do público e do privado entorno do rito do luto: "luto é interno, ter um perfil póstumo acredito que atrapalha a passagem pelo luto. ”. Essa é uma restrição de espectro moral que também aparece nas entrevistas realizadas por Brubaker et al. (2013, p. 18), defendida entre os que consideram que o luto deva ser algo solene e privado, como exemplificado por uma das entrevistadas denominada Katrina: “[...] eu acho que a maioria dessas coisas me deixam desconfortável. A ideia de... eu ficar vendo o luto pessoal deles. Eram comunicações muito pessoais dela para a irmã e eu senti apenas que não deveria estar tão próxima dessas questões privadas" (Id. p. 19).

As variações de ritos são sempre atravessadas por questões culturais. Se a hipótese de uma certa assepsia sobre a morte, o grande interdito do ocidente, for adotada, podemos pensar que a função das redes sociais tem também a ver com escancarar uma "morte a céu aberto", mas de um corpo que não cheira, não remete a sexualidade e não apodrece. Pelo contrário, que se conserva de forma imaginária, limpo e saudável, até o fim dos tempos. Porém, quando o rito desvela a característica pública das mensagens, endereçadas aos mortos ou à comunidade, isso pode gerar um certo estranhamento, tocar no espectro moral de alguns usuários, como creio ser o caso desses respondentes. O paradoxo da morte nos WRS's é também uma báscula que oscila entre a assepsia e a reintrodução do corpus no círculo social dos vivos. 


\section{As pessoas são imortais na internet: estranhamento frente às tecno-imortalidades}

A terceira categoria, e uma das emersões mais interessantes do questionário, concerne ao que poderíamos denominar estranhamentos frente as tecno-imortalidades. Considerei 6 respostas nessa categoria e as considero muito significativas em relação ao percurso teórico que percorri até aqui:

- "A sensação é que a pessoa ainda continuava ali do outro lado da tela".

- “- Não é confortável nem agradável tratar alguém que faleceu como se permanecesse vivo. A presença, por outro lado, atrapalha a despedida e o desligamento"

A natureza assíncrona do Facebook, e das redes sociais em geral, além de promover a insistência do memorial, transformando o arquivo em algo mais dinâmico, ou, parafraseando Brubaker et al. (2013), em tumbas interativas digitais, parece oferecer à uma parcela dos usuários uma sensação de que há um outro do outro lado da tela. Se a função da escrita tem lógica a partir da ausência do interlocutor, as redes oferecem presença do ausente de forma insistente, embaralhando essas duas categorias para o enlutado. Para esse usuário, tal presença concerne também ao que tratamos sobre o luto em Freud, a ideia de que aquilo que remete ao falecido deva ser abandonado pode se transformar em uma tarefa um pouco mais complicada quando suas memórias circulam de forma mais ativa nas redes sociais.

- "Pq ao ver o perfil ve lembra da pessoa como se estivesse viva, como se ela pudesse responder sua mensagem”.

- "Porque nutria inconscientemente a esperança de uma resposta. E era estranho ver o perfil ali sabendo que a pessoa não existia mais atrapalha a despedida e o desligamento.".

Os dois respondentes acima descrevem um ponto fundamental: a da ideia, que um deles até chama de "inconscientemente", de que o morto poderia respondê-los. É claro que historicamente tal ideia não é exatamente nova. Porém, o "como se" estivesse viva, "como se" pudesse responder sua mensagem, nos permite pensar exatamente nessa espécie de simulação bem-sucedida: o suporte digital ofereceria uma sensação de que a morte não habita o ciberespaço. O "como se" faz alusão a ideia de resposta, respondere: garantir, prometer em troca. O perfil, nesse sentido, poderia, para o respondente, "atrapalhar a despedida e o desligamento". 
- "Acho que cria uma sensação de falsa permanência. Me assusta um pouco saber que são exibidas informações tão atuais da pessoa que já morreu”

Essa respondente desvela uma questão muito importante: novamente, da natureza assíncrona dos websites de redes sociais, que pode descompassar o "corte" da morte. Quer dizer, se outrora existia um corte bem demarcado em relação a um antes e um depois de uma morte para um grupo social, sentida como um acontecimento, o respondente aqui descreve o que poderíamos denominar como o "memorial anacrônico": informações "atuais" ou atualizadas de uma pessoa que já faleceu servem como conteúdo que se entrelaça com outros e gera mais conteúdo, justamente o traço "interativo" das tumbas digitais.

- "As pessoas são imortais na internet, não dá pra esquecer ou apagar. reviver isso nem sempre é bom".

Essa fora uma das respostas mais interessantes: "as pessoas são imortais na internet": o que retoma a ideia da internet como um espaço habitado por "entes não-mortos", como descreveu Zizek (2013). O respondente ainda pontua duas características: a de que seria impossível esquecer ou apagar. Isso remonta inclusive para a questão jurídica do "direito ao esquecimento", tão discutida nessa "extraterritorialidade" na qual se caracteriza o ciberespaço.

Lembremo-nos do famoso caso de uma decisão do Tribunal de Justiça da União Europeia (TJUE), na qual o tribunal "entendeu que seria possível determinar a buscadores da Internet, a partir da simples vontade do indivíduo, e em respeito a seus direitos fundamentais de proteção à privacidade, a exclusão de resultados de busca ou a supressão do acesso a suas informações todas as vezes que estivessem presentes as condições fáticas e jurídicas enunciadas no acórdão" (Acunha, 2016):

“M. Costeja González e os Governos espanhol e italiano são de opinião de que a pessoa em causa se pode opor à indexação dos seus dados pessoais por um motor de busca, quando a difusão desses dados por intermédio desse motor a possa prejudicar e quando os seus direitos fundamentais à proteção dos referidos dados e ao respeito pela vida privada, que englobam o «direito a ser esquecido», prevaleçam sobre os interesses legítimos do operador do referido motor e sobre o interesse geral da liberdade de informação." (União Européia, 2014)

A questão que o respondente levanta é justamente de uma espécie de tecno-imortalidade que implicaria no não desligamento: talvez um luto razoável implique em um rito que "apague" o morto do espaço dos vivos, o que se torna complicado a partir do momento em que esse espaço, 
o ciberespaço, derrogue a ideia de uma ausência/esquecimento/apagamento, e que se estruture no sonho de uma positividade permanente.

A quarta categoria eu chamei de testemunhos de sofrimento: os usuários responderam que lhes causava sofrimento o fato de testemunhar o sofrimento dos outros usuários: "era muito dificil ver o sofrimento das pessoas que se relacionavam com ele em vida".

Creio ter feito um panorama geral das modalidades de sofrimento consideradas negativas pelos respondentes. Agora, percorrerei as respostas daqueles que consideraram tal experiência positiva. É interessante pensarmos na intersecção possível desse movimento: a mesma experiência considerada de uma forma positiva ou negativa, dependendo daquele que a viveu.

\section{Experiências positivas a partir do contato com perfis de usuários falecidos}

Adotei o mesmo método para refletir sobre aqueles que relataram experiências positivas no contato com perfis de falecidos: elenquei categorias a partir das respostas daqueles que assinalaram que tal contato ajudou ou ajudou muito. Um número maior de respostas do que os que consideraram a experiência negativa exigiu um número maior de categorias, mas também pela multiplicidade de temas que emergiram. Duas categorias se encontram em uma intersecção entre as duas experiências: tanto respondentes que consideraram positivas quanto negativas ofereceram respostas que podem ser enquadradas em "evocação de lembranças" e "tecnoimortalidades", como exposto na Figura 16. 


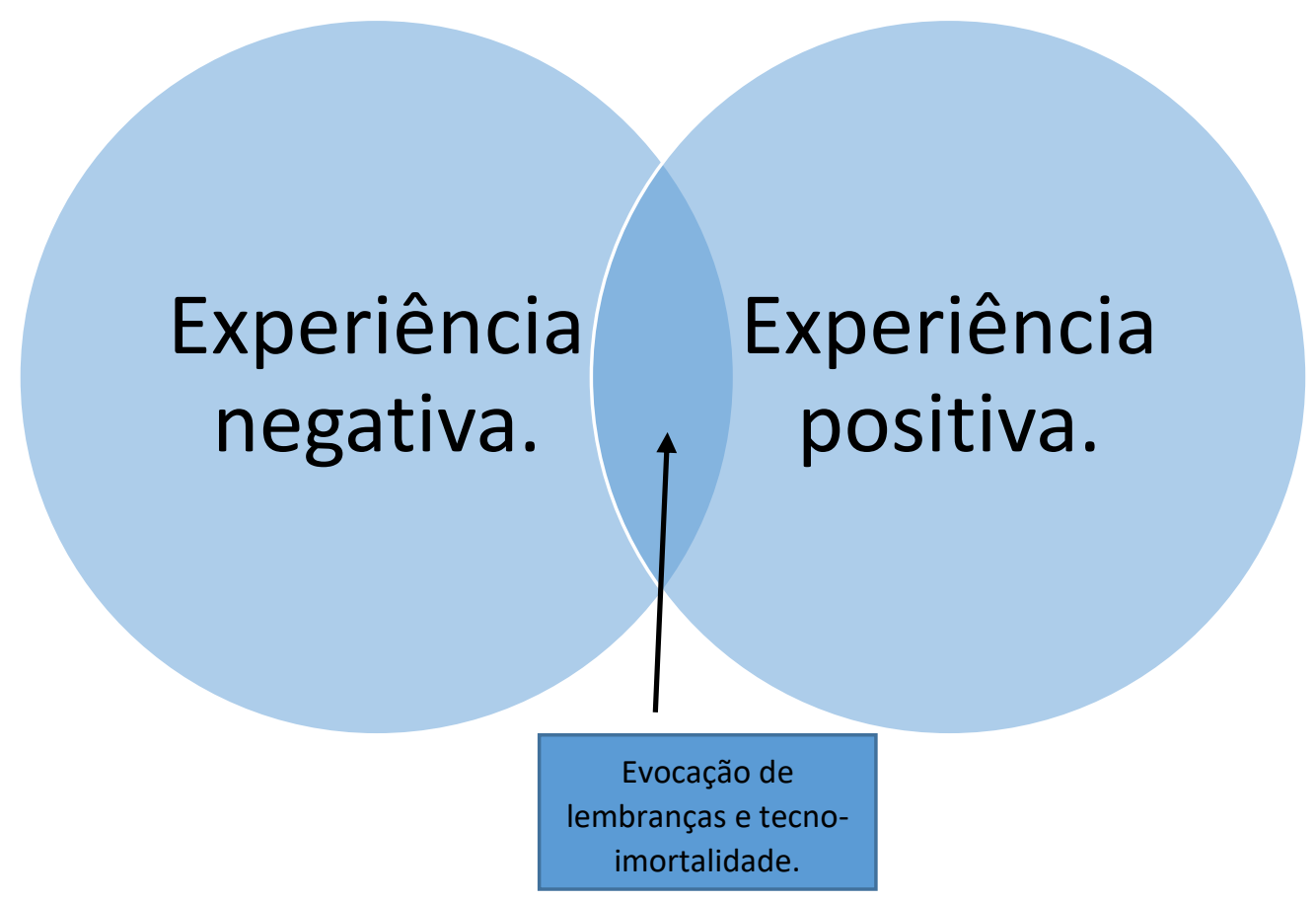

Esse apontamento é importante para tratarmos o luto como uma experiência particular. A problemática e a tentação de arriscar extrair universais a partir de quaisquer pesquisas e análises de dados deve ser refreada a partir da emersão do particular. Exemplo claro: a mesma função, de evocação de lembranças, pode ser considerada por uma parcela dos enlutados como experiência que os ajuda muito e para outra parcela como uma experiência danosa. Apesar de bem aparente nesse exemplo, outros podem ser dados enquanto uma espécie de par oposto: uma das categorias das experiências positivas é justamente sobre aqueles que gostaram de testemunhar relatos de outros enlutados, e com isso sentiram que o morto era "querido" em seu círculo social. Podemos pensar que esse é o par oposto daqueles que foram circunscritos como "testemunhas de sofrimento", pois tiveram experiências negativas justamente por lidar com o sofrimento expresso pelos outros enlutados. Sempre rastreamos uma ambivalência, certa "simetria entre os avessos" nos relatos que os sujeitos fazem de si-mesmos e nas narrativas sobre seus sentimentos.

Entre os 47 respondentes que estão entre os que tiveram uma experiência positiva, a preponderância - 18 deles - diz respeito àqueles que relatam que a lida com os perfis de falecidos serviu para evocar lembranças e apaziguar a saudade. 
Como ilustrado na Figura 17, fiz uma divisão desses respondentes e os distribuí em 8 categorias: “evocação de lembranças", "testemunho de homenagens", "troca de mensagens”, "aceitação da morte/resignação", "notificação", “entendimento", tecno-imortalidade", “outros".

Figura 17

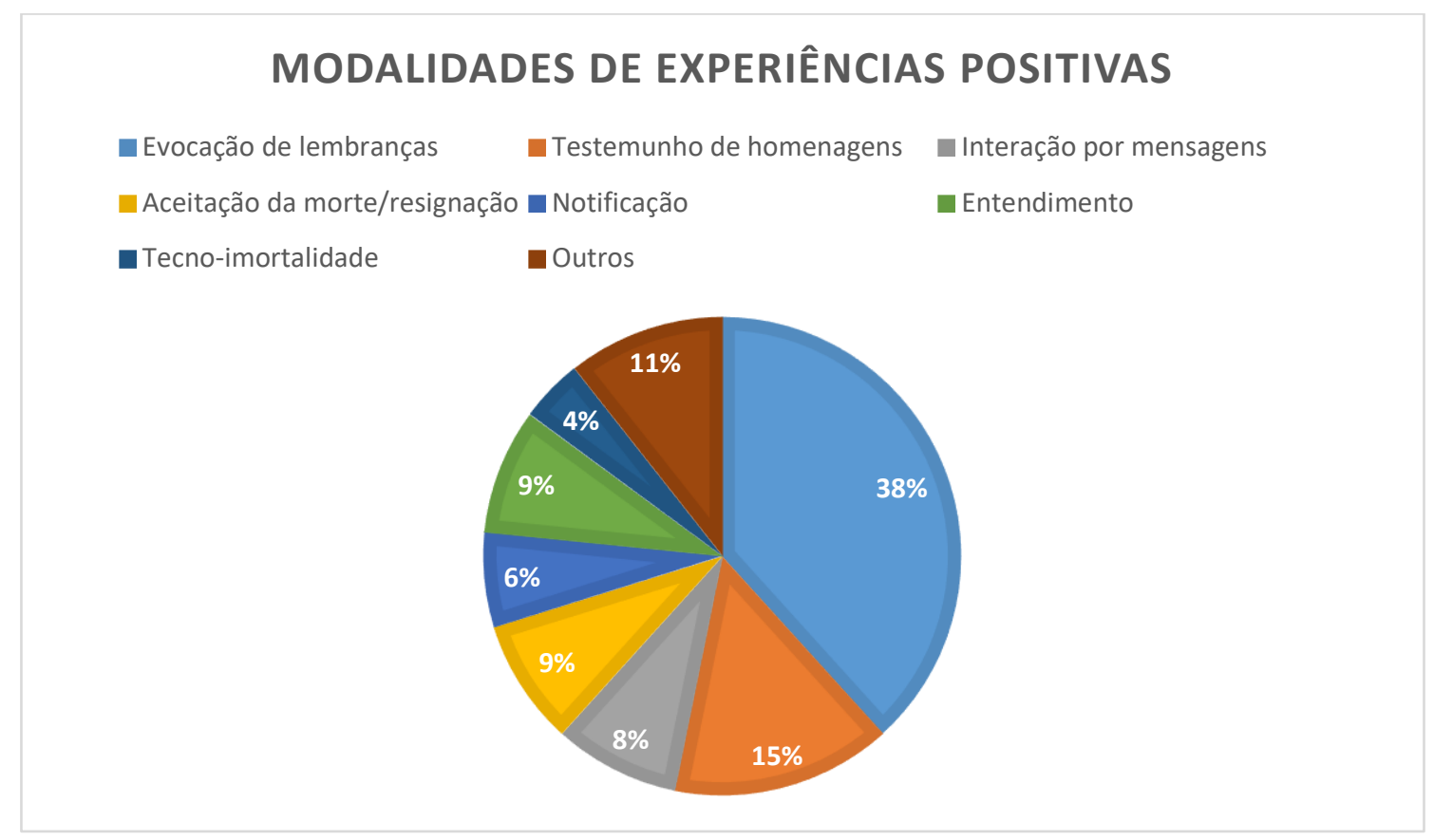

Entre aqueles que escreveram sobre a função de evocar lembranças, muitas das respostas se referem a ideia de apaziguar a saudade através da visita ao perfil. Podemos pensar que esses concebem o perfil como uma espécie de memorial de fácil acesso, e não enquanto uma tumba interativa digital: "A principal ajuda é relembrar bons momentos", "Porque todas as vezes que sinto saudades posso ver as fotos e seus antigos posts que eram muito engraçados”. Um respondente faz uma analogia direta ao álbum fotográfico: "Lembrança do que a pessoa gostava de compartilhar com os amigos da mesma forma que fotos reveladas". A diferença é que, em princípio, um álbum fotográfico se trata de algo estático, que já não circula socialmente e tampouco evoca por vezes a memória de uma forma programada. Assim descreve outro respondente que atribui aos perfis a função de recordar da pessoa: "Ajuda a lembrar que a pessoa existiu, principalmente em datas como o aniversário”. O respondente provavelmente se refere ao automatismo do Facebook, que em datas comemorativas, estimula o círculo social de determinado perfil à parabenizá-lo.

Uma pesquisa retro referida de Brubaker e Hayes (2011) destaca que, no MySpace, rede social que precedeu o Facebook, as interações com os perfis de falecidos através de mensagens 
continuavam intensamente em datas comemorativas, justamente porque a programação relembrava os vivos de deixar uma mensagem para aquele que aniversariava.

Uma das funções da opção de transformar a página do falecido em página memorial é precisamente que tais perfis não apareçam mais em lembranças, datas comemorativas ou sugestões de amizade.

A segunda categoria com maior número de respondentes, 7, eu denominei "testemunho de homenagens" e diz respeito às respostas que descrevem um sentimento positivo ao se deparar com homenagens de outros usuários e perceber o quanto o falecido era querido em seu meio social: "Ajuda a aliviar o sofrimento da família saber o quanto o parente era querido", "Evidencia como a pessoa era querida pelas pessoas por postagens sobre os momentos bons que a pessoa teve”.

Além de tal categoria destacar a função apaziguante do rito no círculo social, o que emerge é também uma função de reconhecimento através da constituição de uma espécie de "grupo de apoio" entre os enlutados. A pesquisa de Brubaker et al. (2013) encontrou muitos relatos de constituições de grupos depois do falecimento de alguém. Inclusive, um de seus principais apontamentos é justamente o quanto se cria uma nova narrativa sobre o morto a partir do contato de diferentes grupos sociais (que por vezes, nem se conheciam) dos quais o falecido fazia parte. Apesar de não ser uma prática que encontrei "formalizada" através de grupos criados no Facebook com esse objetivo entre os respondentes e percorrendo a rede no Brasil, isso é algo que aparece com ênfase entre os respondentes que configuram a categoria "testemunhos de homenagens", mas de forma espontânea e não organizada através da criação de um grupo na rede: "Quando acontece, ainda mais com jovens e de forma repentina, é difícil acreditar. $O$ contato no face ajudou a despedir da pessoa aos poucos, ver mensagens de outras pessoas ajuda a perceber que é difícil para todos, e todos acabam consolando uns aos outros.".

Outro respondente conta que se sentiu acolhido por tal dinâmica: "Ajudou devido a maneira com que o Facebook conecta as pessoas e deixa que as mensagens de apoio e carinho sejam entregues mesmo que não pessoalmente, fazendo com que os familiares e amigos se sintam acolhidos”. Distinto pela comunicação assíncrona e que independe da posição geográfica, tal constituição de "grupo de apoio" fica facilitada e mais inclusiva. Um dos respondentes, já citado anteriormente, caracteriza bem isso: "Creio que receber notícias e fotos de alguns amigos dele me ajudou a preencher um pouco do vazio. Além disto, fizemos o velório muito rapidamente, poucos conseguiram ir. Ver os retornos foi como se mais gente tivesse ido 'se despedir'”. Esse 
relato é muito expressivo se pensamos que a operação do rito depende da lida com o funeral e que por interdições cotidianas muitos dos enlutados podem ficar de fora. Nesse sentido, os websites de redes sociais podem ser assaz funcionais. Alguns serviços profissionais de funerárias oferecem, nesses casos, uma câmera ao vivo no local, passível de ser acessada por um número de token enviado aos familiares ${ }^{13}$.

A terceira categoria, com 4 respondentes, que emergiu na organização e eu denominei "entendimento" corresponde justamente ao que apareceu anteriormente e eu comentei sobre a página retro referida Falecidos do Face (2018): o apaziguamento de um certo modo de sofrer diante de um dessaber sobre a causa da morte. A experiência desses respondentes fora positiva justamente por lhes oferecer uma explicação: "Me informou o que aconteceu”, "Pq assim fiquei sabendo, como ele morreu”, “Através da vida que a pessoa levou ajuda entender algumas coisas".

A categoria denominada "Aceitação da morte/resignação", com 4 respondentes, mantém certa semelhança com a do "entendimento", no sentido de uma identificação com aquele que faleceu através da lida com o perfil do falecido. Para esses usuários, a lida com a ideia da morte do outro através dos perfis, lhes causou mais apreço pela própria vida: "Vendo as fotos do Luciano me fez pensar como a vida é finita e como devemos aproveitá-la ao máximo”, "Ajudou porque fez apreciar mais a vida”, ou uma certa resignação pelo fatalismo - "A aceitar a morte quando o momento chega" - da própria mortalidade.

A categoria "Notificação", com 3 respondentes, serviu para endossar a hipótese da função dos websites de redes sociais em noticiar a morte de alguém através de notas de falecimentos costumeiramente escritas pelas famílias: "Pois foi mais fácil avisar que um ente querido havia falecido para os parentes que moravam longe”.

As 5 respostas da categoria "Outros" não puderam ser agrupadas em algum dos temas pois foram curtas e relativamente mais simples "Me faz refletir", "Fui me desprendendo", o que exigiria excesso de inferência para abrigá-las em alguma das categorias.

Outra categoria que emergiu e que contou com 4 respondentes fora a "Interação por mensagens" e que poderíamos até fundir com tecno-imortalidade, pois se trata de algo que envolve uma suposta troca: "Porque parecia q a pessoa de alguma forma receberia a mensagem", "Porque as vezes quando dava saudades, eu mandava uma mensagem por lá!’. Essa ideia é justamente

\footnotetext{
${ }^{13}$ Cf. um exemplo da Funerária Madre Teresa: http://funerariamadreteresa.com.br/Funeral-Online
} 
a mesma que Zizek (2013) descreve ao falar do brinquedo virtual Tamagotchi, a de que a motivação de tratar um não ente virtual como um ente é justamente supor que do outro lado da tela haja alguém. Para os que atrelam isso a uma experiencia positiva, algo que ajudou no luto, parece ser bem funcional. Um dos respondentes sublinha com precisão a questão do "como se": "Porque escrever no perfil do falecido, é como se estivesse interagindo com ele, então você coloca pra fora sua angústia”. O efeito de enviar uma mensagem ao morto se desdobra nos efeitos para si mesmo: nesse caso, "colocar para fora sua angústia".

Um último respondente eleva a questão da interatividade ao seu radical:

"ajudou no sentido de estar mais a par da vida desta pessoa, porque às vezes não temos muita convivência, e através da rede social podemos saber mais coisas sobre a pessoa. E também estar se comunicando, enviando mensagens de carinho".

Apesar de revelar um luto e a função da lida com o perfil do falecido enquanto algo que o ajudou, ele parece não ter a dimensão de que o outro está de fato morto: se refere a vida da pessoa para "estar a par", à convivência, à comunicação. A marca da interação é bem sublinhada: o perfil do falecido passa a apresentar novidades constantemente e possibilita novos eventos, acontecimentos, que vão da constituição de novas narrativas sobre o falecido aos "novos encontros".

A última categoria apresenta uma conversação com essa e também emergiu nas respostas daqueles que consideraram a lida com os perfis de falecidos algo negativo: a "tecnoimortalidade", com 2 respondentes: "Ajudou porque foi uma forma de mantê-lo vivo, de lembrar quando já não lembrava mais, como o aniversário e fotos”, “"Ajudou por que é como manter parte da pessoa ainda viva". Novamente, um dado que endossa o levantamento da pesquisa de Brubaker e Hayes (2011) que apontou para a amplificação da interação e um prolongamento a partir da evocação de lembranças comemorativas. No segundo caso, "manter parte da pessoa ainda viva" é a marca da ambivalência: se a operação que viabiliza um luto necessita que o enlutado em algum momento possa deixar o morto partir, um "arquivo interativo", característica das tumbas interativas digitais, pode tanto representar uma experiência negativa quanto positiva para o enlutado.

\subsection{Duas escutas sobre a questão: entrevistas com enlutados}


Além do questionário, resolvi, por inspiração metodológica, replicar a experiência de Brubaker et al (2013) e aplicar entrevistas abertas sobre o tema, para poder escutar o que pessoas que perderam alguém querido e que tinha um perfil no Facebook tinham a dizer. A ideia era justamente se deparar com uma escuta livre de uma estrutura pré-concebida para então pensar se os temas que emergiam eram convergentes com aqueles destacados na análise do questionário.

As duas pessoas escutadas não se tratavam de respondentes do questionário, justamente para evitar a arbitrariedade que as perguntas já organizadas poderiam implicar. O primeiro respondente, que aqui irei denominar Bruno, de 26 anos, perdeu um de seus melhores amigos em um acidente de carro há dois anos. Tal amigo lhe era muito importante e durante sua fala (Cf. Anexo 1) chorou diversas vezes. Sua fala é muito interessante, perpassa quase todas as categorias retro referidas e se aproxima bastante dos assuntos mencionados. Para Bruno, ter acesso ao perfil de seu amigo, realiza um efeito apaziguador quando ele é atravessado pela saudade. Assim, ele pode revisitar o perfil, como um álbum fotográfico, para lhe evocar memórias. Porém, para além da posição passiva, também comenta sobre o perfil que circula nas redes de forma ativa:

"Quando eu sinto saudade, assim que é... queria olhar, lembrar de uma coisa boa, desestressar a cabeça, pensar alguma coisa que, mano, foi boa, ou que aconteceu de bom... eu paro mano, e às vezes até o próprio Facebook aparece aqueles lembretes de: ah!, isso aqui aconteceu há três anos atrás, isso aqui aconteceu há quatro anos atrás e vira e mexe aparece alguma foto que ele tava junto, algum momento que ele não tá aparecendo a foto mas sabia que ele estava lá, me lembrava da gente indo para o que a gente estava indo fazer, me lembrava da gente voltando, me lembrava do que aconteceu ali no meio" (Anexo 1).

Bruno, além de se referir ao perfil como um espaço de visitação, algo que concerne ao escópico ao revisitar as fotografias, destaca a questão que se refere também a programação: o Facebook, ao convidar o usuário à revisitar fotos antigas, através dos lembretes, atualiza o perfil do falecido no espaço dos vivos e promove tais "encontros inesperados".

Outra questão que se destaca é sobre as mensagens. Mais do que artificio apaziguador, parte do rito fúnebre, o Facebook parece facilitar a ideia de enviar mensagens para os falecidos. A questão que podemos pensar é se se trata de um movimento no qual a mensagem serve para circundar o meio e produzir efeito apaziguador, se serve apenas enquanto monólogo, ou se o enlutado supõe que a mensagem seja direcionada ao morto, se se trata de uma mensagem para o morto. Bruno, ao falar que escrevia mensagens e fazia postagens para o falecido, foi 
questionado sobre tal questão, para entendermos se a ideia era de que o receptor seria o falecido ou não. A resposta apresentou um mote muito interessante:

"Não para ele, é... eu acabei fazendo, por exemplo, às vezes eu já escu..., eu
tenho... a gente tinha um relacionamento... que a última coisa que a gente fez
junto foi ir num show de uma banda que a gente gostava muito, que é o
Mumford and Sons, e de lá pra cá eles soltaram algumas músicas [...] E aí, me
mexia, me tocava bastante as músicas. E aí, eu gravava um pedaço da música,
gravava, cantando, que seja... um pedaço da música, ou então pegava um
trecho da música e postava e falava: pô, se você estivesse ouvindo tenho
certeza que estaria gostando. Então, dividir aquele momento com ele, mas não
dividir com ele, deixar registrado que era um negócio que eu queria que ele
estivesse ali pra acompanhar ou ter a experiencia" (Anexo 1).

Essa passagem revela bem a ambivalência da questão da mensagem: Bruno claudica, se equivoca, vai pendulando entre a ideia de que seu interlocutor participa presente da cena ou (e) não. Mais para frente, comenta algo muito significativo: o fato de que usa um código próprio, criado entre ele e o falecido, para enviar tais mensagens:

"Mencionava ele com palavras que eu sabia que ele entenderia que eu estava falando dele. A gente... eu o chamava de Charlie e ele me chamava de Jack e muita gente não sabia, tipo: quando a gente se chamava assim um perto do outro o pessoal dizia: Mas com quem você tá falando?”

A partir dessa informação, podemos pensar que, situada no jogo entre presença e ausência, além do efeito apaziguador do envio de mensagens, tal mensagem era enviada com uma "senha", acessível e entendida apenas por aquele que já não está entre nós. Ou seja, a mensagem era endereçada justamente ao morto. Derrida (2008), se refere à ideia de falar ao morto enquanto uma prática de despedida, de um adeus, não apenas enquanto rito simbólico que retorna ao grupo e produz um efeito apaziguador.

Os assuntos que emergiram coincidem com os tratados no questionário. Bruno destaca durante toda a entrevista uma relação ambivalente em relação ao Facebook, que lhe traz certo conforto, mas que também lhe evoca saudade:

"Fariam falta naquele momento, então, não é a mesma coisa que tá tendo na hora, a mesma experiencia que eu tive quando estava naquela foto com ele, quando tava naquele momento com ele, mas traz um pouco do alivio, mesmo que seja momentâneo ali, pro motivo da visita [...]" (Anexo 1)

O entrevistado também se refere aos momentos em que a família do falecido o marca em publicações sobre ele, o que lhe causa um pequeno incômodo:

"Eu tento entender o lado da pessoa que está fazendo aquilo, entendeu? Eu acho que ela está tentando buscar ali um pouco de alivio do mesmo jeito que eu busquei em outros momentos. Então, pode ser que incomode, mas nada que eu vá falar: vou bloquear, vou remover esse comentário [...]" (Anexo 1) 
Outra questão interessante que emerge diz respeito a comparação entre um luto que experimentou antes da existência do Facebook, de seu avô, e o luto pela perda de seu amigo. Bruno discute então a possibilidade de um "prolongamento" do luto por causa do Facebook. Descreve que já não lembra nitidamente do rosto de seu avô, enquanto consegue lembrar dos traços precisos de seu amigo. Pergunto então se isso poderia ter a ver com o fato de seu amigo sofrer uma morte por acidente, menos esperada. Bruno diz que sim, mas que também pensa na insistência do perfil do Facebook enquanto motivo para esse prolongamento. A questão da imagem aparece para ele, mas enquanto um memorial acessível de uma forma atemporal: "quem quiser, vai saber como era o Rafael no dia, meses antes de ele morrer, que ele tava bem, que ele tava se divertindo, como ele era" (Anexo 1). A ambivalência de Bruno com relação ao perfil de seu amigo fica clara em suas respostas “[...] E aí eu fico meio dividido: é bom mas é ruim" (Anexo 1), quer dizer, ao mesmo tempo que serve enquanto um memorial mais acessível, um espaço no qual ele pode enviar mensagens endereçadas ao falecido, revisitar momentos e conservar certa estética do falecido, a insistência do perfil, de acordo com Bruno, pode estar relacionada com um certo "prolongamento" do luto.

A segunda entrevistada, de heterônimo Carolina, perdera uma amiga de sua filha de forma repentina, em um trágico acidente de bicicleta. A adolescente tinha a idade de sua filha e frequentava sua casa intensamente. Em seu relato, uma das primeiras questões que emergem é sobre o referente da morte, algo que fora trabalhado no capítulo "Pensar a morte", justamente por se referir a morte encefálica como critério de atestar a morte da pessoa. Carolina narra que um dos grandes sofrimentos que passou foi precisamente o fato de que um representante dos pais anunciava no grupo dos pais de WhatsApp informações desconexas e pouco precisas em relação ao que acontecera com a menina. Internada no interior de São Paulo, teve complicações em sua transferência e seu estado degenerou para a morte encefálica. A primeira questão que se destaca é justamente a informação de seu estado em um grupo de pais do WhatsApp, o desdobramento sobre a morte, que na entrevista com Carolina aparece enquanto uma morte incerta (Anexo 2), antes de um "anúncio oficial":

"A gente... as pessoas falavam pelo WhatsApp o que estava acontecendo, que
ela teve morte cerebral e a gente mandava mensagem para mãe, porque os pais
não divulgaram, não queriam dizer que ela teve morte cerebral, mesmo porque
eles não queriam acreditar nisso e a gente também não acreditava a gente
queria que... insistir que ela não tivesse morrido e tem aquele processo todo
que eles fazem os testes para saber se realmente deu a morte cerebral... e a
gente não queria que chegasse o dia desses testes, a gente queria que ficasse
pra amanhã, e pra amanhã e pra amanhã... minha filha escrevia para mãe dela
e dizia: a Maria nunca ia desligar os aparelhos se fosse por você tia, ela nunca 
ia desligar e a gente ficava rezando para que ela não desligasse mesmos aparelhos..." (Anexo 2)

A questão que mais se destaca é essa ideia de uma morte possível de ser combatida, como se tratasse de um estado passageiro, reversível, algo que fora tratado nos capítulos anteriores como a ideia de "morte domada", interdita, apagada. Quando escancarada no grupo de pais, e se tratando de uma morte acidental de uma adolescente, algo da ordem do contingente, porém inesperado, Carolina relata um estranhamento e raiva daqueles que se referiam a falecida e aos ritos de passagem antes do anúncio fúnebre "oficial", que viera publicamente mais tarde através da escola:

"A escola inteira divulgava coisas no Snap, no Stories, no Facebook, postando coisas assim "onde vai ser o enterro?", "que horas vai ser o funeral?", e a gente, assim, quando você não tem uma nota oficial "foi diagnosticado morte cerebral", você espera, porque você tem uma esperança ainda, não importa... a gente tinha essa esperança" (Anexo 2)

Além disso, algo que a incomodou tem a ver com o ponto do anúncio fúnebre, através de informações por vezes ambivalentes: "não dá para ficar dizendo, 'olha, agora morreu', 'olha, agora não morreu'. Isso durou uns quatro dias de angústia, as pessoas rezando a noite toda" (Anexo 2).

Carolina relata uma relação dolorosa com o perfil da falecida, com o qual prefere não se deparar. Apesar de o pai fazer atualizações em datas comemorativas, postando fotos de sua filha, Carolina prefere não ver por contar que isso evoca sentimentos dolorosos que se referem a esse tempo, esses dias nos quais não se sabia se a menina sobreviveria ou não. Sobre se deparar com o perfil da falecida, que continuou publicado, Carolina diz:

"Eu acho que me fez mal e... eu vejo que outras, por exemplo na minha casa, ninguém comenta nada. Às vezes eu mostro uma foto, as vezes eu tô olhando fotos antigas no computador e acho alguma coisa dela e mostro para os meus filhos"

Diante do relato, podemos pensar que a experiência traumática, além da ruptura da qual se trata a morte de uma adolescente, inesperada, acidental, acompanhada então de mensagens imprecisas sobre seu estado de saúde, remete a duas questões trabalhadas em capítulos anteriores: a primeira concerne ao anúncio fúnebre, marco importante no rito simbólico que anuncia a partida de alguém, escrita costumeiramente nas redes sociais, sobretudo no Facebook, que pode declinar a ideia do que seria o anúncio "oficial" de uma morte, a partir do momento em que a informação é pulverizada de uma forma mais horizontal, a partir de um "colapso do contexto"; e a segunda, sobre como a questão da morte interdita pode ser repensada a partir do 
momento em que passa a ser anunciada e a circular em um espaço que, ao menos em primeira instância, seria destinado aos vivos.

O que fica evidente nas duas escutas, corroborando com os temas emergentes do questionário, é justamente o papel preponderante das redes sociais no processo de luto, independente da experiência ser considerada positiva ou negativa para o enlutado, é difícil pensar em uma perda no contemporâneo que não precise considerar o perfil do falecido e os desdobramentos de seu legado digital para pensarmos nas atitudes atuais perante a morte e no luto.

Nas considerações finais, organizarei os temas que emergiram e quais proposições possíveis a partir de tal análise. 


\section{Considerações Finais}

Nesse capitulo irei apresentar considerações sobre as principais questões que emergiram em cada capítulo e conclusões possíveis do trabalho como um todo. Depois, farei considerações sobre desdobramentos a partir dessa pesquisa.

No capítulo 1, decidi contar um pouco sobre a urgência subjetiva que me levou a escolher tal tema de pesquisa. A partir de uma dúvida que concernia ao próprio percurso acadêmico, escrevi sobre minha posição em relação ao trabalho e algumas reflexões teóricas e práticas que me acompanharam desde o início.

No capítulo 2, descrevi como foi dada a escolha do objeto de pesquisa: porque escolhi o Facebook como meio e como se deu o processo histórico de passagem dos denominados cemitérios virtuais para as redes sociais como espaços privilegiados para pensarmos nas atitudes perante a morte no contemporâneo. Nesse capítulo, também realizei uma revisão bibliográfica de outras pesquisas que se propuseram a trabalhar sobre as redes sociais, sobretudo das pesquisas que se referiam a morte, ao morrer e ao luto a partir das redes. Tal capítulo foi importante para circunscrever esse trabalho entre as pesquisas que consideram as redes sociais como um espaço distinto para o pesquisador recolher dados. Apesar de não ter encontrado pesquisas em Psicologia Social que já trabalham com esse tema, essa revisão pode ser importante para os pesquisadores que decidam se engajar nesse campo. Afinal, entre outras dificuldades, nenhuma das pesquisas está publicada em português.

No subcapitulo 2.2, "Das identidades aos modos de subjetivações digitais", continuei a revisão bibliográfica, mas de modo mais amplo, considerando como alguns autores que trabalham entre a Psicologia e o Campo Digital definem a questão da identidade: entre eles, Jed Brubaker e Sherry Turkle. Também destaquei a dificuldade de pensar em uma identidade digital desconsiderando conceitos fundamentais que perpassam, por exemplo, as concepções de corpo, objeto, sujeito. Por isso, sublinhei a importância de pensarmos - ao trabalharmos na intersecção entre a Psicologia e o Campo Digital - em modos de subjetivação, em como se dá o efeito de sujeito entre aqueles que aparecem na rede e quais as suas implicações e desdobramentos.

Para isso, também contei com uma explanação no subcapítulo 2.3, do porquê adotei o conceito de "digital" ao invés de "virtual". Basicamente, considerei que "redes sociais virtuais" existiram desde sempre no campo da linguagem humana, desde que houvesse a dimensão de um terceiro. 
A adoção da ideia de "digital" deu conta de pensarmos em um momento preciso, no qual a comunicação pode ser intermediada pela digitalização da informação, traduzida por apenas dois valores (0 ou 1). Esse capítulo foi pensado para servir de base epistemológica para trabalhos na Psicologia que elencam o Campo Digital como um elemento fundamental do contemporâneo.

No Capítulo 3, "Pensar a Morte", introduzi uma reflexão sobre outra questão fundamental do trabalho: a dizer, tratar a morte enquanto conceito em uma pesquisa circunscrita entre o que poderíamos considerar um campo da Psicologia Social da Morte. Em tal capítulo, descrevo algumas concepções da morte que consideram diferentes saberes, da filosofia de Epicuro a Psicanálise de Freud, passando pela História (Ariès) e a Antropologia (Vincent, Lévi-Strauss). No subcapítulo 3.1, faço um aporte de diferentes leituras sobre a morte e o morrer na Filosofia, sobretudo entre Max Scheller, Heidegger e Paul Ricoeur, sempre considerando o quanto adotar determinada concepção sobre a morte implica uma determinada Psicologia. Por isso, no subcapítulo 3.2, "Uma Psicologia da Morte ou para a Morte" faço uma pequena revisão bibliográfica sobre autores que privilegiaram a questão e se transformaram em referências para o campo, como Robert Kastenbaum, Ruth Aisenberg, Ernest Becker, Elisabeth Kubler-Ross, e os desdobramentos teóricos e epistemológicos que implicam a visão de uma Psicologia que possa tratar as atitudes perante a morte enquanto conceito chave para pensar o ser humano.

No capítulo 4, "Sobre o luto", apresentei diferentes concepções sobre o luto, demonstrando interpretações possíveis a partir do texto referencial do tema, Luto e Melancolia, de Freud. Enfoquei a importância fundamental do rito fúnebre para um luto razoável, algo que converge entre os autores. Além disso, tentei apontar diferenças e semelhanças entre Freud e Lacan sobre o tema, levando em consideração autores como Allouch. Ana Costa e Parkes. Ao lidar com a emersão da ideia de "escrever um luto", realizei que tal capiítulo fora importante para pensarmos na questão da escrita em direção aos mortos e em direção à comunidade machucada, algo que apareceu bastante nas respostas dos questionários.

No capítulo 5, discorri sobre o método, importante para o leitor se localizar e identificar a forma com a qual o trabalho se delineou; contei sobre a inspiração metodológica a partir de um trabalho precedente, de Jed Brubaker - Brubaker, Jed R. Hayes, Gillian R. Dourish, Paul. Beyond the Grave: Facebook as a site for expansion of death and mourning, 2013, que elencou categorias, a partir do mesmo assunto, e que me inspirou tanto para a organização metodológica do trabalho, quanto para a construção do questionário que disponibilizei no Survey Monkey e para a realização das entrevistas. Além disso, comentei sobre a análise de dados categorial, 
descrita por Bardin, e como eu realizei, organizei e conversei com os dados a partir das respostas do questionário.

No capítulo 6, denominado "Análise de dados", elenquei, a partir das respostas encontradas no questionário e de duas entrevistas, categorias temáticas para refletir sobre as atitudes perante a morte e como poderíamos pensar o luto a partir do advento dos websites de redes sociais.

Algumas constatações foram realizadas então:

- A preponderância de respondentes mulheres, o que corrobora com outras pesquisas sobre o luto levantadas;

- Entre os respondentes, quando confrontados sobre qual destino gostariam que fosse dado ao seu perfil depois da própria morte, existe uma tendência entre os mais novos de manutenção e entre os mais velhos de exclusão, o que pode indicar uma diferença geracional em relação a concepção de função dos perfis nas redes sociais;

- Entre os respondentes, apareceu um dado muito importante: ao menos 42,25\% deles ficaram sabendo da morte da pessoa através do Facebook, o que implica a rede social em uma função de notificação fúnebre. Se outrora essa função era realizada pelos familiares e publicada no jornal impresso, agora, tanto a plataforma quanto o conteúdo do texto se transformam a partir dos WRS's. Diferentemente dos jornais, não há mais o caráter impessoal, o que implica os amigos e família em uma mensagem bem particularizada, costumeiramente com elementos biográficos que dizem respeito àquele que a pública: suas memórias, interações e afetos. Duas consequências mais gerais disso: a primeira, ao apresentar a morte de uma forma mais natural, diverge da ideia de uma morte interdita na contemporaneidade. Ou seja, poderíamos pensar que as redes sociais reintroduzem a ideia da morte em uma sociedade que pretende excluí-la, um exemplo disso é a página "Falecidos no Face", descrita em tal capítulo, que, apesar de poder servir para um voyeurismo da morte que busca explicá-la, ao menos reintroduz sua ideia no cotidiano. Mais que isso: quando pensamos em um contínuo, demarcamos um momento histórico do rito, em um deslocamento dos obituários, a partir dos cemitérios virtuais para as redes sociais. Eulalio Ferrer (2003, p. 21), ao escrever uma história dos obituários e sua relação com uma "linguagem da morte", traça bem esse percurso:

"Ao longo deste século, a linguagem da morte passou da pedra conservada (epitáfio) para a tinta indelével (obituário). No início do século XXI, a morte caminha por meios mais complexos, como a internet, onde proliferam cemitérios virtuais e obituários eletrônicos, fazendo uso de uma singular "tinta intangível'. O ritual da morte em seu máximo esplendor". 
O autor (Id. p. 275) constata, a partir das páginas de cemitérios virtuais e derivações das mesmas, tons mais informais e despreocupados nas "conversações informais com os mortos". Ao se deslocar para os WRS's, os obituários se tornam ainda mais informais e particulares, com mensagens destinadas ao próprio morto em interação direta com o perfil do falecido. Uma das razões para tal deslocamento deriva do colapso do contexto, afinal, o Facebook, diferentemente dos cemitérios virtuais, ao menos em princípio, não é exclusivamente destinado aos mortos, mas aos vivos. Na passagem dos obituários dos jornais para os cemitérios virtuais, alguns elementos permaneceram: “[...] o símbolo da cruz na parte superior ou central do obituário, seguido do nome do defunto, o lugar e a data da morte, as circunstâncias do falecimento, as siglas D.E.P. ${ }^{14}$,, entre outros. Tal estrutura não se mantém no deslocamento da preponderância da nota fúnebre e do obituário, dos cemitérios virtuais para os websites de redes sociais.

O segundo desdobramento: por se tratar de um meio de comunicação assíncrono e mais horizontal, a ideia de um "emissor oficial", de uma "autoridade" que atesta a morte de uma pessoa, está mais fragmentada, isso fica bem claro em uma das entrevistas na qual as pessoas passam a realizar o rito fúnebre, escrevendo sobre o morto e enviando condolências à família, antes da "morte oficial" da menina, que ainda não passara por exames para constatar a morte encefálica. Esse movimento nas redes produziu sofrimento tanto nos amigos mais íntimos quanto nos familiares;

- Entre os respondentes, a grande maioria teve alguma interação com o perfil do falecido, o que indica que devemos pensar nas redes sociais para quaisquer trabalhos que visam compreender o luto na contemporaneidade. Dos modos de interação, ficou evidenciado que existe uma certa preponderância entre ler/olhar/visualizar e enviar mensagens para os perfis dos falecidos. Tais modos de interação também emergiram nas entrevistas;

- É impossível afirmar que a interação com os perfis de falecidos se trata de uma experiência positiva ou negativa: entre os respondentes, a questão é bem distribuída e em alguns casos ambivalente. Se para uma parte deles, poder revisitar o perfil de alguém querido traz certo afago, para outros pode produzir um certo efeito de "prolongamento" do luto, além do incômodo descrito pelos "encontros inesperados", a saber, quando o perfil de um falecido aparece no cotidiano de alguém através da programação automática, em lembretes de aniversário, sugestão de amizades, marcação de fotos, entre outros. Tal aparição gera estranhamento e incômodo em alguns usuários;

\footnotetext{
${ }^{14}$ Descanse em Paz.
} 
- Das categorias encontradas tanto entre os que consideraram a experiência de interação com perfis de falecidos uma experiência negativa quanto entre aqueles que a consideraram positiva, uma chamou a atenção e que eu denominei tecno-imortalidades: quando os respondentes consideram que os perfis dos usuários falecidos se tratam de uma continuidade da vida, uma parte fica angustiada, e outra encontra nisso certo alívio. Em uma das entrevistas, quando o tema apareceu, um dado foi muito significativo: ao comparar o luto de um amigo com o luto de seu avô, o entrevistando conta que não lembrava mais da fisionomia de seu avô e que sentia certa resignação em poder revisitar o perfil de seu amigo para recordar. O "como se" estivesse vivo se desdobra em duas direções: a primeira, a de um simulacro; a segunda, a de uma dúvida. Ambas não pormenorizam a questão, há interação mesmo "como se";

- A constatação de que a partir dos WRS's, a interação com os falecidos através de mensagens, celebrações em datas comemorativas ou outros ritos, se outrora diminuía com o passar do tempo, agora é mais contínua. Algo atestado pela pesquisa de Brubaker e Hayes (2011). Isso também impacta na questão do rito: poderíamos trabalhar com a hipótese de que também se trata de desconsiderar a morte enquanto pausa, fim, e tratá-la, assim como é a dinâmica no ciberespaço, de um contínuo sem fim, permanente, de estímulo constante, o que empresta ao conceito de Tumbas Interativas Digitais a noção dessa insistência de deslocar o cadáver para o campo dos vivos, em uma espécie de positividade sem fim;

- A possibilidade do rito deslocada da questão espacial: a partir da nota fúnebre no Facebook, é possível, além de prestar condolências e produzir uma narrativa sobre o falecido, participar do rito fúnebre mesmo à distância. Da publicação ao vivo do ato aos informes contínuos, aquilo que se restringia ao espaço e tempo específicos do rito fúnebre, o "poder se despedir", que, quando não realizado, gerava uma forma muito precisa de sofrimento, se torna mais acessível com os WRS's. Podemos pensar em um colapso do contexto enquanto atrelado a um tempoespaço específicos, particularizando muito mais cada um dos rituais de um mesmo falecido.

- A pesquisa de Brubaker et al. (2013), que considera que o encontro de diferentes narrativas em uma plataforma assíncrona propicia uma maior interatividade entre os enlutados sobre e então a partir das informações que concernem ao morto, produzindo assim novas narrativas de forma contínua, deixando o arquivo mais interativo e derrogando um limiar que outrora era mais concreto entre o mundo dos vivos e o dos mortos, forja o conceito de Tumbas Interativas Digitais. Tal conceito pode ser enriquecido com o fato de que aparece diversas vezes neste trabalho a existência de uma interação que se refere a enviar mensagens para o morto, e não sobre o morto (ou para o morto, mas em direção a comunidade machucada). Essa modalidade 
fica bem explicitada na primeira entrevista em anexo, na qual o garoto que perdera seu amigo envia mensagens para o mesmo com "códigos" que apenas o morto poderia reconhecer. Derrida (2008), em uma de suas mais belas falas, aborda essa questão ao falar diretamente à Lévinas, na ocasião da morte do mesmo, no cemitério de Pantin. A quem se fala quando alguém se vai? Em princípio, se despede do próprio morto, em linha reta, em direção a ele. Não apenas como um discurso que volta sobre si mesmo enquanto função: aquele que acolhe uma comunidade ferida, consola, e é endossado por um conceito confuso de trabalho de luto: "falar diretamente, dirigir-se diretamente ao outro, e falar ao outro que amamos e admiramos, antes de falar dele. Em princípio, dizer-lhe Adeus.” (Id. p. 16). Essa forte descrição de Derrida poderia nos servir para pensarmos que, no aspecto psicológico, poder falar diretamente ao morto, nas redes sociais, pode significar justamente uma fase de simbolização, do ritual, algo que diz respeito a importância de redimensionar toda a dimensão simbólica quando alguém que nos é querido se vai, quando lidamos com aquilo que Lacan chamou de buraco no Real;

Diante de tais pontos, podemos concluir que os websites de redes sociais, sobretudo o Facebook, abrigam elementos importantes para a dinâmica do rito fúnebre na contemporaneidade, o que descaracteriza tais perfis como simples "Paródias da imortalidade", como Robert Redeker (2018) os define - como se fossem simples artifícios, como os farmacêuticos, em uma luta contra o envelhecimento - pelo contrário, reintroduzem no cotidiano uma forma peculiar de referência aos mortos, de tanatografias, mais pessoais e informais que outrora. Além disso, a interação com os perfis de falecidos fora preponderante entre os respondentes, o que desvela uma importância do campo digital no rito fúnebre e no próprio processo de luto, além de destacar uma atitude perante a morte característica do contemporâneo.

Além desses pontos levantados, o presente trabalho abre um horizonte de possíveis para futuras pesquisas. Cada um dos recortes realizados pode se desdobrar em levantamentos que se referem aos modos de subjetivação nos websites de redes sociais: gênero, idade, geração, modalidade de luto, modalidade de morte, entre outros. Além disso, realizar que a forma como pensamos a morte implica diretamente no trabalho do psicólogo, social ou clínico, e do pesquisador. É necessário interrogar também a eleição de um conceito específico de morte na estrutura de uma Psicologia Social da Morte. Se, por um lado, o ser-para-a-morte influenciou toda a formação de gerações que trabalham com o cuidado paliativo, é interessante podermos pensar outros modelos teóricos para a atuação do psicólogo em tal área, como o "vivo-até-a-morte" de Paul Ricoeur. 
Fica muito evidente também a necessidade de outras produções que pensem os websites de redes sociais e a própria internet como modalidades de subjetivação, não apenas como efeito da qualidade ou da moral das relações contemporâneas. Aí se insere uma fronteira bem delicada entre uma Psicologia que recai para a moral e outra que se abre para a escuta de um fenômeno e suas implicações subjetivas: das paixões, dos discursos, das subjetivações ao sofrimento psíquico. Nesse sentido, o trabalho tomou cuidado para não mergulhar em uma busca de universais a partir de experiências particulares, tampouco em adotar uma crítica que pressupõe todos os problemas contemporâneos como efeitos de um suposto império da tecnologia. Pelo contrário, foi alterado, torcido, colocado em xeque diversas vezes para que se orientasse na direção de escutar, e assim, ao tentar se desatrelar de paradigmas anteriores, poder fazer os dados conversarem mais entre si do que servirem para provar alguma hipótese prévia. 
Referências bibliográficas

ABEL, O. IN RICOEUR, P. (2012) Vivo até a morte: seguido de fragmentos. Prefácio Olivier Abel; Posfácio Catherine Goldenstein. Tradução Eduardo Brandão. São Paulo: Editora WMF Martins Fontes, 2012

ACUNHA, F. J. G. Democracia e transconstitucionalismo: "direito ao esquecimento", extraterritorialidade e conflito entre ordens jurídicas. Rev. direito GV, São Paulo, v. 12, n. 3, p. 748-775, Dec. 2016. $\quad$ Disponível em <http://www.scielo.br/scielo.php?script=sci_arttext\&pid=S1808-

24322016000300748\&lng=en\&nrm=iso>. Acesso em: 25 Set. 2018 . http://dx.doi.org/10.1590/2317-6172201631.

ALLOUCH, J. Erótica do luto no tempo da morte seca. Tradução de Procopio Abreu. Rio de Janeiro: Companhia de Freud, 2004

AMADO, J. A morte e a morte de Quincas Berro D’Água. São Paulo: Cia das Letras, 2008

ARIÈS, P. História da morte no Ocidente: da Idade Média aos nossos dias. Tradução de Priscila Viana de Siqueira. Rio de Janeiro: Nova Fronteira, 2012

BECKER, Ernest, A negação da morte. Tradução de Luiz Carlos do Nascimento Filho. Rio de Janeiro, Record, 1991.

BE Right Back IN Black Mirror. Direção: Owen Harris Escrito por: Charlie Brooker. Zeppotron, Channel 4, 2011. (48 min.)

BONANNO, G. A; KELTNER, D. H., A.; HOROWITZ, J. M. When Avoiding Unpleasant Emotions Might Not Be Such a Bad Thing: Verbal-Autonomic Response Dissociation and Midlife Conjugal Bereavement. Journal of Personality and Social Psychology 1995. Vol. 69. No. 5. 975-989

BORGES. J. L. Destino e obra de Camões IN Borges no Brasil. Organizador Schwartz, Jorge. São Paulo: Editora Unesp, 2001.

BOYD, D. Why Youth (Heart) Social Network Sites: The Role of Networked Publics in Teenage Social Life. MacArthur Foundation Series on Digital Learning - Youth, Identity, and Digital Media Volume (ed. David Buckingham). Cambridge, MA: MIT Press, 2007

BRUBAKER, J. R; HAYES, G. R; DOURISH, P. Beyond the Grave: Facebook as a site for expansion of death and mourning, 2013

BRUBAKER, J. R.; HAYES, GILLIAN. R. "We will never forget you [online]": An empirical investigation of post-mortem MySpace comments. In: CONFERENCE ON COMPUTED SUPPORT COOPERATIVE WORK, 2011, Hangzhou, China. Anais... Hangzhou, 2011

BRUBAKER, J. R. (2015). Death, Identity, and the Social Network. UC Irvine. ProQuest ID: Brubaker_uci_0030D_13596. Merritt ID: ark:/13030/m5mh29sx. Disponível em <https://escholarship.org/uc/item/6cn0s1xd>. Acesso em: 02 Mar. 2018

CERTEAU, M. de. A escrita da história. Tradução de Maria de Lourdes Menezes. Rio de Janeiro: Forense, 2011

COSTA, A. Litorais da Psicanálise. São Paulo: Escuta, 2015. 
DEBIEUX, M. A psicanálise frente à questão da identidade. Trabalho apresentado no $9^{\circ}$ Encontro Nacional de Psicologia Social promovido pela ABRAPSO, em Belo Horizonte, 1997, na mesa redonda intitulada Perspectivas Teóricas do Estudo da Identidade

DEGROOT, J. M. (2014). "For whom the bell tolls": emotional rubbernecking in Facebook memorial groups. Death Studies, 38(2), 7984. http://doi.org/10.1080/07481187.2012.725450

DIGITAL Legacy Association. What is Digital Legacy? Disponível em $<$ https://digitallegacyassociation.org/about/what-is-a-digital-legacy/> Acesso em: 5 de setembro de 2018

EPICURO. Carta sobre a felicidade (A Meneceu). Tradução de Álvaro Lorencini e Enzo de Carratore. São Paulo: Editora Unesp, 2002

FACEBOOK, O que acontecerá com a minha conta se eu falecer? Disponível em <https://www.Facebook.com/help/103897939701143?helpref=faq_content>. Acesso em: 02 Abr. 2018

, Como faço para informar o falecimento de um usuário ou uma conta no Facebook que precisa ser transformada em um memorial? Disponível em $\langle$ https://www.Facebook.com/help/150486848354038?helpref=related $>$. Acesso em 02: Abr. 2018

FALECIDOS DO FACE, Página de Facebook, Disponível em $<$ https://www.Facebook.com/falecidosface/?fb_dtsg ag=AdwklkaNZEPgzUESzD8IBMfLyBFsE5mtmmYHJjfBxotYw\%3AAdyj6-nLBY5uRiShAhZxa9LSD0JRsMK216fz634isXosQ>. Acesso em: 22 Set. 2018

FERRER, E. EI lenguaje de la inmortalidad. Pompas fúnebres. México: FCE, 2003

FERRY, L. A tentação do cristianismo - De seita a civilização. Tradução de Véra Lucia dos Reis. Rio de Janeiro: Objetiva, 2011.

FRANÇA, G. V. de. Medicina legal. 10. ed. Rio de Janeiro: Guanabara Koogan, 2015

FRANCO, S. de G.; WONDRACEK, K. Freud e o Caso AB: entre a esperança e a ruína. Rev. latinoam. psicopatol. fundam., São Paulo, v. 10, n. 4, p. 591-613, Dec. 2007. Disponível em <http://www.scielo.br/scielo.php?script=sci_arttext\&pid=S141547142007000400003\&lng=en\&nrm=iso>. Acesso em: $04 \quad$ Set. 2018. http://dx.doi.org/10.1590/S1415-47142007000400003

FOWLER, B. The obituary as collective memory. Nova York: Routledge, 2007

FREUD, S. Considerações atuais sobre a guerra e a morte (1915-2010a) IN FREUD, S. Introdução ao narcisismo: ensaios de metapsicologia e outros textos (1914-1916). Tradução de Paulo César de Souza. São Paulo: Companhia das Letras, 2010

Introdução ao narcisismo: ensaios de metapsicologia e outros textos (19141916). Tradução de Paulo César de Souza. São Paulo: Companhia das Letras, 2010b

A Transitoriedade IN FREUD, S. Introdução ao narcisismo: ensaios de metapsicologia e outros textos (1914-1916). Tradução de Paulo César de Souza. São Paulo: Companhia das Letras, 2010c

Nota sobre o "bloco mágico". In Freud, S. O eu e o id, "autobiografia" e outros textos (1923-1925). Tradução de Paulo César de Souza. São Paulo: Companhia das Letras, 2011 
Totem e tabu: algumas concordâncias entre a vida psíquica dos homens primitivos e a dos neuróticos (1912-1913). Tradução de Paulo César de Souza. São Paulo: Penguin Classics Comapnhia das Letras, 2013

Luto e Melancolia. Tradução, introdução e notas de Marilene Carone. São Paulo: Cosac Naify. 2014

GOLDIN, D. IN Cultura escrita, literatura e história: conversas de Roger Chartier com Carlos Aguirre Anaya, Jesus Anaya Rosique, Daniel Goldin e Antonio Saborit. São Paulo: ARTMED, 2001

HEIDEGGER, M. Ser e Tempo, Parte II. Tradução de Marcia Sá Cavalcante Schuback. Petrópolis, Editora Vozes, 2005

HUIZINGA, J. O outono da Idade Média. Tradução de Francis Petra Janssen. São Paulo, Cosac Naify, 2010

HOLLOWAY, K. FC, A name for parente whose child has died. Duke Today, 26/05/2009. Disponível em <https://today.duke.edu/2009/05/holloway_oped.html>. Acesso em: 31 Ago. 2018

JURKIEWICZ, R; ROMANO, W. Doença arterial coronariana e vivência de perdas Arquivos Brasileiros de Cardiologia, v.93, n.4, p.352-359, 2009

KASTENBAUn, R. AISENBERG. Psicologia da Morte. Tradução de Adelade Petters Lessa. São Paulo: Pioneira, Ed. Da Universidade de São Paulo, 1983

KATIE Z; GACH C. F; BRUBAKER, J. "Control your emotions, Potter": An Analysis of Grief Policing on Facebook in Response to Celebrity Death. SIG Paper in Word Format. ACM Trans. Web, 1, 2, Article 47 (November 2017), 13 pages, 2017. Disponível em: 〈https://doi.org/10.1145/3134682>. Acesso em: 10 Abr. 2018.

KEHL, M. R. Duas Mães. Publicação em página oficial de Facebook. Publicado em 21/03/2018, Disponível em: <https://www.Facebook.com/pg/mariaritakehloficial/posts/?ref=page_internal >. Acesso em: 31 Ago. 2018

KUBLER-ROSS, E. Sobre a morte e o morrer. Tradução de Paulo Menezes. São Paulo: Martins Fontes, 1987

LACAN, J. Situação da psicanálise e formação do psicanalista em 1956. Tradução de Vera Ribeiro. Rio de Janeiro: Jorge Zahar, 1998

Zahar, 1979

O seminário, livro 1: Os escritos técnicos de Freud. Rio de Janeiro: Jorge

Rio de Janeiro: Zahar, 2010

O Seminário, Livro 6: o desejo e sua interpretação. Tradução de Claudia Berliner Rio de Janeiro: Zahar, 2016

LEMOS, L. F. S; CUNHA, A. C. B. da. Concepções Sobre Morte e Luto: Experiência Feminina Sobre a Perda Gestacional. Psicol. cienc. prof. [online]. 2015, vol.35, n.4, pp.11201138. ISSN 1414-9893. http://dx.doi.org/10.1590/1982-3703001582014. 
LERUDE, M. Como se coloca a questão das identificações na era da internet generalizada? IN Intoxicações eletrônicas: o sujeito na era das relações digitais/ organizadoras Angela Baptista, Julieta Jerusalinsky. Salvador: Ágalma, 2017

LÉVY, P. Cibercultura. Tradução de Carlos Irineu da Costa. São Paulo: Editora 34, 2010 O que é o virtual? Tradução de Paulo Neves. São Paulo: Editora 34, 2011

LÉVI-STRAUSS, Claude, O suplício do Papai Noel. Tradução de Denise Bottmann. São Paulo: Cosac Naify, 2008

KLASTRUP, L. "I didn't know her, but...": parasocial mourning of mediated deaths on Facebook RIP pages. New Review of Hypermedia and Multimedia 21, 1-2: 146-164. 2014 Disponível em <http://doi.org/10.1080/13614568.2014.983564>. Acesso em 08 Mar. 2018.

MILLER, J. El partenaire-síntoma. Traducido por Dora Gladys Saroka. Buenos Aires: Paidós, 2008

NUSSELDER, A. Interface fantasy: a Lacanian cyborg ontology. Cambridge: MIT Press, 2009

OLIVEIRA, J. B. A. de; LOPES, R. G. S. O processo de luto no idoso pela morte de cônjuge e filho. Psicol. estud. [online]. 2008, vol.13, n.2, pp.217-221. ISSN 1413-7372. Disponível em <http://dx.doi.org/10.1590/S1413-73722008000200003>. Acesso em: 20 set. 2018

PAIVA. G. J. de. O papel da religião no gerenciamento do medo da morte. In Morte, psicologia e religião. Organizadores: Marta Helena de Freira; Thiago A. Avellar de Aquino e Geraldo José de Paiva. São Paulo: Fonte Editorial, Edições Terceira Via, 2016

PAIVA, L. E. Falando da morte com crianças. IN A Arte de Morrer - Visões Plurais. Organizadores Dora Incontri e Flanklin Santana Santos. SP: Editora Comenius, 2007

PARKES, C. M. Luto: estudos sobre a perda na vida adulta. Tradução de Maria Helena Franco. São Paulo: Summus, 1998

QUEAU, Philippe. O tempo do virtual. IN Imagem-máquina: a era das tecnologias do virtual; organização de Andre Parente; tradução de Rogério Luz. Rio de Janeiro: Editora 34, 1993

RICOEUR, Paul. Vivo até a morte: seguido de fragmentos. Prefácio Olivier Abel; Posfácio Catherine Goldenstein. Tradução Eduardo Brandão. São Paulo: Editora WMF Martins Fontes, 2012

PEIXOTO, J. L. Morreste-me. Porto Alegre: Dublinense, 2015

ROBERTS, P. VIDAL, L. Perpetual care in cyberspace: A portrait of Web memorials. OMEGA-Journal of Death and Dying 40(4): 521-45, 2000

ROBERTS, P. The living and the dead: Community in the virtual cemetery. OMEGAJournal of Death and Dying 49(1): 57-76, 2004

ROBINSON, A. Escrita: uma breve introdução. Tradução de Camila Werner. Porto Alegre: LePM, 2016

RUSCHEL P. P. Quando o luto adoece o coração: luto não-elaborado e infarto. Porto Alegre: Edipucrs; 2006

SÁNCHEZ, J. L. A história cotidiana às margens do Nilo. Tradução de Francisco Mahães, Marcelo Neves, Carlos Nougué e Michel Teixeira. Barcelona: Folio, 2007 
SANTOS, M. C. C. L. dos. Conceito médico-forense de morte. Revista da Faculdade de Direito, Universidade de São Paulo, São Paulo, v. 92, p. 341-380, jan. 1997. ISSN 2318-8235. Disponível em: <http://www.revistas.usp.br/rfdusp/article/view/67369>. Acesso em: 14 mai. 2018. doi:http://dx.doi.org/10.11606/issn.2318-8235.v92i0p341-380

SCHELER, M. Morte e Sobrevivência. Tradução de Carlos Morujão. Lisboa: Edições 70, 2017

SCHIVANI, M.; SOUZA, G. F. de; PEREIRA, E. Pirâmide "holográfica": erros conceituais e potencial didático. Rev. Bras. Ensino Fís., São Paulo , v. 40, n. 2, e2506, 2018 . Disponível em $\quad<$ http://www.scielo.br/scielo.php?script=sci_arttext\&pid=S180611172018000200607\&lng=en\&nrm=iso>. Acesso em: 20 Set. 2018. Epub Dec 18, 2017. http://dx.doi.org/10.1590/1806-9126-rbef-2017-0186

SUMITRA, M 2011, Tribe Practices Finger Cutting as a Means of Grieving, 16 December 2011, Oddity Central. Disponível em: <http://www.odditycentral.com/pics/tribe-practicesfinger-cutting-as-a-means-of-grieving.html > Acesso em 24 Jun. 2018.

LEAYER, T. HIGHFIELD, T. (2016): Visualising the ends of identity: pre-birth and postdeath on Instagram, Information, Communication \& Society, DOI:

10.1080/1369118X.2016.1259343

THOMAS, L. (1996) Prefácio IN Sentido oculto dos ritos mortuários: morrer é morrer? Bayard, Jean-Pierre. São Paulo: Paulus, 1996

TURKLE, Sherry. A vida no ecrã: a identidade na era da internet. Tradução de Paulo Faria. Lisboa: Relógio D’Água Editores, 1997

UNIÃO EUROPEIA. Tribunal de Justiça da União Europeia. Processo C-131/12. Acórdão do Tribunal de Justiça (Grande Secção) ECLI:EU:C:2014:317. Partes: Google Spain SL e Google Inc. contra Agencia Española de Protección de Datos (AEPD) e Mario Costeja González. Pedido de decisão prejudicial: Audiência Nacional-Espanha. Relator: M. Ileši. Grande Secção. 13 mai. 2014. Jornal Oficial, Luxemburgo, 7 jul. 2014, p. 4. Disponível em: <http://curia.europa.eu/juris/document/document.jsf;jsessionid=9ea7d2dc30d585485bc5ed1a 4a0698fdcbaf380e2b01.e34KaxiLc3qMb40Rch0SaxuNb3z0?text=\&docid=152065\&pageInd ex $=0 \&$ doclang $=P T \&$ mode $=$ req $\&$ dir $=\& o c c=$ first $\&$ part $=1 \& \operatorname{cid}=262988>$. Acesso em: 25 Jun. 2018.

VAIL. K. E., J. JUHL, J. ARNDT, M. VESS, C. ROUTLEDGE, B.T. RUTJENS, When death is good for life: considering the positive trajectories of terror management, Pers. Soc. Psychol. Rev. 16 (2012) 303-329.

VIEIRA, W. Obituário ontem e hoje: do biográfico fast food a uma "literatura de jornal". Ilha Desterro, Florianópolis , v. 70, n. 1, p. 143-159, Apr. 2017. Disponível em <http://www.scielo.br/scielo.php?script=sci_arttext\&pid=S2175-

80262017000100143\&lng=en\&nrm=iso>. Acesso em: $05 \quad$ Set. 2018. http://dx.doi.org/10.5007/2175-8026.2017v70n1p143.

WALTER, T. HOURIZI, R. MONCUR, W. PITSILLIDES, S. (2012) Does the internet change how we die and mourn? Overview and analysis. OMEGA64(4): 275-302.

WEISSBERG, J. Real e Virtual. IN Imagem-máquina: a era das tecnologias do virtual; organização de Andre Parente; tradução de Rogério Luz. Rio de Janeiro: Editora 34, 1993 
WIENER, N. Deus. Golem e Cia. Tradução de Leonidas Hegenberg e Octanny Silveira da Mota. São Paulo: Cultrix, 1971

Cibernética e Sociedade: $O$ uso humano de seres humanos. Tradução de José Paulo Paes. São Paulo: Cultrix, 1968

WITTER. J. S. Os anúncios fúnebres (1920-1940) IN A Morte e os Mortos na Sociedade Brasileira. Organizador José de Souza Martins. São Paulo: Editora Hucitec, 1983

ZIZEK, S. O amor impiedoso (ou: sobre a crença). tradução de Lucas Mello Carvalho Ribeiro. Belo Horizonte: Autêntica Editora, 2013 


\section{ANEXOS \\ ANEXO 1}

Entrevista Bruno (heterônimo), 26 anos, São Paulo

Vou fazer o meu relato da experiência que eu tenho mais recente, que é de um grande amigo meu, que eu conheci na faculdade, que é o Rafael. a gente acabou se conhecendo por motivos de esporte. Eu tinha acabado de entrar na faculdade e ele meio que tava bastante envolvido com o time de rúgbi e ele meio queria me puxar para o time fui na onda dele acabei entrando no time da faculdade com ele e a gente se divertiu bastante, mas mano, ele se tornou se não o meu melhor, tá ali no círculo dos meus melhores amigos talvez a segunda pessoa mais importante que eu tenha convivido nessa minha fase mais adulta assim.

É (pausa), ele faleceu no acidente de carro há dois anos atrás agora completa 2 anos agora, e (pausa) foi terrível na época não era tão maduro como eu sou agora, inclusive amadureci muito depois da morte dele, por muita coisa que a gente convivia e eu senti falta depois de não ter ele. É, mas entrando de vez no assunto, as redes sociais eu acho que foram meio que uma faca de dois gumes assim (pausa) tanto ajudou em momentos que eu paro, olho e falo: puta, tô com saudade. Quando eu sinto saudade assim que é, queria olhar, lembrar de uma coisa boa, desestressar a cabeça, pensar alguma coisa que, mano, foi boa, ou que aconteceu de bom eu paro mano, e às vezes até o próprio Facebook aparece aqueles lembretes de ah!, isso aqui aconteceu há três anos atrás, isso aqui aconteceu há 4 anos atrás e vira e mexe aparece alguma foto que ele tava junto, algum momento que ele não tá aparecendo a foto mas sabia que ele estava lá, me lembrava da gente indo para o que a gente estava indo fazer, me lembrava da gente voltando, me lembrava do que aconteceu ali no meio.

Mas do mesmo jeito faz aquela falta, porque é uma pessoa que estava muito presente: me ajudou muito, acompanhou minha mãe quando tava no hospital, fez coisas que pessoas próximas a mim não fizeram. Ele fez, ele foi... se tornou muito importante num espaço de tempo muito curto. É, então acho que é isso, ele ajuda porque mata a saudade, acho que matar a saudade para mim é importante, mas um pouco que você sente a falta e sentir falta é ruim, mas mata a saudade é bom, lembrar do que do que foi bom, do que é bom, é muito bom. Emociona bastante, sem dúvida, porque lidar com a perda... nunca, acho que nunca vai ser fácil, nunca foi fácil, mas é 
rápido, é passageiro depois lembra, para pra pensar, cada um acredita no que acredita, mas eu acredito que pelo menos a presença dele está comigo o tempo inteiro, e olhar vê ele ali, ver uma foto com ele, escrever alguma coisa para ele, postar alguma coisa para ele acho que é meio que aliviante na hora e bom, não tem porque ficar escondendo não tem que ficar segurando: ele vira... acaba virando um álbum de fotografia. Querendo ou não, registrado para sempre mano, tá na internet, infelizmente agora vai ficar e vai ser difícil alguém tirar alguma coisa da internet, principalmente uma conta do Facebook sua, no Instagram tá lá, você tira se você quiser, se não tá ali para sempre cara. Você vai conseguir ver, lembrar de coisas boas e também sofrer um pouco com as coisas tristes 20, 30 anos depois. Eu acho que como eu falei tem muito lado bom e tem um lado natural de ficar magoado por não ter, por ter perdido a pessoa e tudo mais. Bem no geral falando e tentando resumir um pouco é isso que eu sinto.

- Entrevistador: Quando você falou sobre escrever mensagem e fazer postagem para ele, como é isso?

Não para ele, é... eu acabei fazendo, por exemplo, às vezes eu já escu..., eu tenho... a gente tinha um relacionamento... que a última coisa que a gente fez junto foi ir num show de uma banda que a gente gostava muito, que é o Mumford and Sons, e de lá pra cá eles soltaram algumas músicas, e algumas músicas que puta, eu tinha certeza que se ele ouvisse ele ia gostar pra caralho, porque eu sabia do gosto dele, a gente conversava disso, era uma conversa que a gente tinha cotidianamente, a gente falava de música, a gente tava o tempo inteiro. Porra, literalmente a última coisa que a gente fez junto foi assistir ao show dos caras. E aí, me mexia, me tocava bastante as músicas. E aí, eu gravava um pedaço da música, gravava, cantando, que seja, um pedaço da música, ou então pegava um trecho da música e postava e falava: porra, se você estivesse ouvindo tenho certeza que estaria gostando. Então, dividir aquele momento com ele, mas não dividir com ele, deixar registrado que era um negócio que eu queria que ele estivesse ali pra acompanhar ou ter a experiencia. É isso.

- Entrevistador: Aí você mandava por mensagem?

Não, nunca cheguei a mandar diretamente. Eu postava na minha própria página. É... ou então postava no meu feed de fotos do Instagram. Sem nem marcar ele, acabava às vezes nem marcando ele. Mencionava ele com palavras que eu sabia que ele entenderia que eu estava falando dele. A gente, ele me chamava de Charlie e ele me chamava de Jack e muita gente não sabia, não, tipo: quando a gente se chamava assim um perto do outro o pessoal dizia: Mas com quem você tá falando? Tá ligado? E às vezes eu escrevia, falava: - Ou, Jack, o negócio é, queria 
que você estivesse ouvindo essa música, ou, tô vendo um negócio aqui que gostaria que você tivesse visto, que você estivesse vendo comigo e só, esta ligado? Só para expressar um pouco o momento, poder falar, ter um sentimento um pouco mais tangível de que eu passei uma mensagem para ele, sem que ele vá ler ou não, mas dar um pouco dessa sensação de que eu tornei real e não só tipo, eu parado e sentado no quarto conversando com ele, entendeu? Torna um pouco mais tangível.

- Entrevistador: E com o perfil dele, você chegou a interagir alguma vez?

Eu entrei no perfil dele algumas vezes. Peguei fotos do perfil dele para usar, mas, num marquei ele numa foto, não marquei o nome dele em uma publicação. Já fui marcado em muitas fotos que falavam sobre ele, principalmente da família dele, porque eu tive um contato muito grande então, a família dele sempre tem foto dele lá jogando rúgbi e eu estou junto, coisas do tipo, então eles acabam me marcando. E aí eu curto, comento, tipo... também é um momento que eu gosto de dividir com eles porque eu sei que todo mundo sofreu a mesma perda que eu ali. Então, mano, eu gosto de interagir e saber que ainda tem esse carinho, que ele gerou esse carinho. Então, mas não faço isso. Porque eu não sei qual é o momento das outras pessoas ali. Não sei se agora, tipo, tenho a família dele no Facebook. Então, tipo, vou marcar ele numa publicação, e eu não sei se eles estão em um momento frágil, não sei se a mãe dele está se sentindo ainda mal com isso... então fico com um pouco de pé atrás de postar alguma coisa e acabar causando um desconforto desnecessário, sendo que o objetivo ali é totalmente o contrário em todas as vezes, entendeu?

- Entrevistador: e o Facebook dele se manteve do jeito que estava ou virou página memorial?

Então, virou pagina memorial. Se não me engano, o irmão dele entrou com pedido para se tornar memorial, mas o Instagram dele tá lá. O Instagram está como se ele estivesse vivo ainda, só ninguém posta nada, tá ligado?

- Entrevistador: Você chegou a entrar no Instagram?

Eu não entro com frequência. Mas já entrei em alguns momentos que, tipo, bate a saudade, vou lá, dou uma olhada. Entro no Instagram, vejo alguma coisa, vejo o que ele tinha postado..., mas interagir, mandar mensagem, eu ainda não cheguei a fazer.

- Entrevistador: E quando você faz essa visita, é reconfortante?

É emocionante. Muitas vezes é. É bom, é produtivo, porque tipo, eu estava ali, num momento que eu gostaria de sentir aquela relação, aquele bem-estar que eu sentia quando eu estava com 
ele. Então pega, me lembra, me faz lembrar de momentos que eram bons, que me fizeram bem e fazem falta hoje. Fariam falta naquele momento, então, não é a mesma coisa que tá tendo na hora, a mesma experiencia que eu tive quando estava naquela foto com ele, quando tava naquele momento com ele, mas traz um pouco do alivio, mesmo que seja momentâneo ali, pro motivo da visita. Porque a visita é quase sempre tipo, tô com saudade dele. Agora, então, a maioria das vezes que eu tenho, que eu escuto uma música e penso: Caralho, o rafa iria curtir pra caralho isso. E aí eu entrava lá e olhava as coisas dele. E aí olhava um pouco, via, emocionava obviamente. E aí falava, mano, não precisava ficar ali perdendo horas. Matava a saudade, como se eu estivesse vendo uma foto do meu irmão ou da minha mãe que não estão perto de mim agora e depois segue a vida, vida que segue.

- Entrevistador: Uma curiosidade... se você viesse a falecer, preferiria deixar o seu aberto, transformar em página memorial ou exclui-lo? Já pensou sobre isso?

Não pensei, mas, aqui de bate e pronto, eu acho que deixaria essa opção para as pessoas mais próximas de mim. Eu acho que depois que a pessoa, tipo, não é muito mais o que eu quero daqui pra frente, sabe? Eu acho que seria mais um bem-estar das pessoas que estavam próximas a mim. Por exemplo: se meus familiares pudessem escolher: Ah, quero que esteja aberto, ou então quero que vire uma página memorial. Se fosse trazer um pouco de conforto para eles ali no momento eu acho que, transformar numa página memorial, acho que ótimo, tá ligado? Pra usar mesmo de lembrança, para pegar alguma foto, para ver, para matar uma saudade. Mas também não deixar aquele negócio permanente. Eu acho que uma página memorial é boa por causa disso. Você não pode mandar mensagem, você fica ali, meio, tipo, realmente como um álbum, tá ligado?

- Entrevistador: Quando você diz isso, é porque já se deparou com algum falecimento, ou esse ou outro, que isso te incomodou ou causou algum estranhamento? Alguma questão que você achou inadequada ou qualquer coisa que você tem restrição?

Não, eu particularmente acho que não cara. Porque eu tento entender sempre, por exemplo, se alguma pessoa postou de alguém que faleceu. Já aconteceu vários casos, tipo, eu estou marcado em vários posts da família do rafa. Tem momentos que eu acho que, até eu, tipo, já sofri, estou em um momento que estou em um momento alegre ali... eu não me deixo parar e falar, e ficar triste, tá ligado? Eu tento entender o lado da pessoa que está fazendo aquilo, entendeu? Eu acho que ela está tentando buscar ali um pouco de alivio do mesmo jeito que eu busquei em outros momentos. Então, pode ser que incomode, mas nada que eu vá falar: vou bloquear, vou remover 
esse comentário. Eu acho que não, tem que respeitar... a pessoa que tá envolvida tem que ter o direito de poder, mesmo, expressar um sentimento, aproveitar ali da ferramenta que é o Facebook, e etecetera. Até para poder buscar um alivio, matar uma saudade, não sei.

- Entrevistador: Tem mais alguma coisa que você acha que seria interessante acrescentar? Você comentou do álbum de fotografias, mas escolhe o Facebook e o Instagram para visitar, por que essa escolha?

Primeiro porque eu acho que a gente passa 24 horas do dia no celular. A gente não consegue sair disso. Inclusive eu me incluo nisso. A gente tá viciado, a gente tá viciado no prático: o Instagram tá aqui, o Facebook tá aqui, não preciso perder 3 segundos que já estou com a tela aberta. Já to vendo, acho que é o negócio de ser mais instantâneo, mais prático. Posso perder meu celular, meu computador, posso estar na Hungria que vou acessar meu Facebook e vai estar tudo lá. Por isso, pelo menos eu, por isso de a gente não usar mais algum de fotografia. Na minha casa não tem, mano, os álbuns de fotografia a gente tava até vendo esses dias, tudo mofado debaixo do armário. Facebook nunca vai acontecer isso cara. E as fotos tão lá, tão com qualidade. Se um dia o cara quiser pegar e fazer uma foto impressa ele faz uma foto impressa. Então acho que essa praticidade o Facebook traz nessas horas também. Pelo menos para mim é assim. Acho que é um negócio muito fácil, muito prático. Eu o uso desse jeito.

- Entrevistador: E antes do Facebook, você passou por algum luto?

Ah, teve o falecimento do meu avô, mas a gente nunca foi muito próximo dos nossos avós. Pela distância que a gente sempre morou longe. Mas era nossos avós, a gente se dava bem e se gostava. Então cara, eu acho que foi um negócio mais rápido, mais fácil de aceitar, durou muito menos tempo o luto, do que agora que a gente pode pegar e olhar a foto tipo, eu lembro de ficar a semana seguinte inteira que o Rafa morreu entrando vendo algumas fotos, lembrando de uns jogos que a gente ligou, tá ligado?

- Entrevistador: Então você acha que poderia ter esse efeito de prolongar o luto?

Eu acho que tem. Eu acho que tem. Eu não sei, eu não senti a mesma coisa. Não dá para comparar o relacionamento que eu tinha com meu avô e o relacionamento que eu tinha com o Rafa em nenhum aspecto. Mas acho que eu desliguei do meu avô muito mais rápido do que eu me desliguei do Rafa. Foi mais fácil de lidar. Não sei se é o jeito certo de interpretar mas, foi mais rápido, beleza, morreu, era o avô, vou lembrar dele quando entrar na casa dele, porque 
minha avó ainda mora lá, vou lembrar dele quando alguém falar alguma coisa que ele costumava falar sempre e é isso.

- Entrevistador: Era uma morte esperada?

Era, mais ou menos. Sendo bem honesto era. Ele não se cuidava muito, tinha alguns casos clínicos ruins e acabou indo no hospital, nunca foi um cara que quis se cuidar, nunca foi um cara que respeitou a opinião dos outros, e isso foi prejudicial para a saúde dele, e a gente já estava esperando que mano, uma hora ou outra isso ia acontecer. É, também não sei se esse pode ser um dos motivos de eu ter me desligado tão rápido, por ser um negócio que a gente já esperava, mas, eu tenho nítido para mim que eu sofri mais com a morte do Rafael, por mais tempo pelo menos, sofrer mesmo. Tipo, de sentir dor, aquele, angustia da pessoa ter morrido. Da falta da pessoa. Aquilo lá eu senti mais tempo do que eu senti quando meu avô faleceu por exemplo. Eu tenho isso claro, com certeza. Mas em compensação não tenho mais tanto acesso as coisas do meu avô, por exemplo. Não tenho, a imagem do meu avô já não é mais tão nítida para mim. Não sei se é uma coisa boa ou ruim. Eu lembro do tipo físico dele, eu lembro mais ou menos do rosto dele, eu lembro que ele usava óculos e era carequinha assim. Mas aspecto físico dele, não sei, a gente não tinha muita foto dele velho... ele não gostava de tirar foto. A gente tem foto dele novo assim, na casa, jovem, a gente tem bastante foto dele. Mas, não sei, eu lembro dele tipo físico: baixinho, troncudinho, parrudo, com as coxas gigantescas assim... mano, mas lembrar dos detalhes assim, lembrar como era o rosto dele: já não é uma memória tão nítida assim. Lembro dele bem mais ou menos. Já o Rafael, se passar um cara um pouco parecido com ele na rua eu falo: parece o Rafa lá.

\section{- Entrevistador: Mas isso você acha que tem a ver com o Facebook?}

Acho que sim. Eu não tenho a memória do meu avô. Mas não sei, eu não lembro muito o que aconteceu aquela época e em outros períodos também, além da morte do meu avô. Mas eu acho que ter o acesso, poder ver, poder manter essa memória presente, essa presença dele o tempo inteiro, presença mesmo virtual, e a hora que você quiser, a hora que você precisar, também tem esse lado ruim. Porque pode ser que faça você sofrer mais, mas também tem o lado bom de que, porra, eu vou saber, aliás, quem quiser, vai saber como era o Rafael no dia, meses antes de ele morrer, que ele tava bem, que ele tava se divertindo, como ele era. Não vão poder conhecer a pessoa Rafael, mas vão poder ter uma imagem que, muitas vezes era a imagem que todo mundo tinha dele. Porque para mim, essa morte, no velório dele foi muita gente. Até a mãe dele não esperava que fosse tanta gente, foi gente demais no cemitério. E todo mundo tem 
uma memória dele de ser um cara muito bom, um cara muito alegre, e as fotos dele, eu sei porque já entrei muitas vezes, todas expressam isso cara. Não tem um momento que ele não tava... nem fazendo charminho, ele tava nitidamente feliz, e várias vezes com muitos amigos perto, e isso foi refletido depois que ele morreu. E aí eu fico meio dividido: é bom, mas é ruim. É isso, acho que deu para dar uma passada por tudo. Acho que falei o que eu precisava falar a respeito desse assunto. Minha visão é essa. 


\section{ANEXO 2}

Entrevista Carolina (heterônimo), 45 anos, casada, São Paulo, SP

Minha filha tinha uma amiga na escola que elas se tornaram muito amigas e de repente ela estava frequentando a minha casa quase todos os dias, elas viajavam juntas, e ela vivia muito tempo na minha casa, com a família com meus filhos e a gente conviveu mais ou menos durante 5 anos, e no ano passado, no mês que ela estava completando 15 anos, aconteceu um acidente com ela no mês das férias, a gente também estava de férias viajando e ela ficou em São Paulo foi para o interior com a família dela com os pais e ela estava saindo de um hotel com a mãe, e andando de bicicleta, tava com fone de ouvido e não ouviu o barulho do carro e o carro atropelou ela. E ela foi parar no hospital e nós ficamos sabendo disso, assim, de uma forma muito estranha, apareceu no grupo da escola que alguém estava precisando, sem falar o nome da menina: que tinha uma garota da escola tava precisando sangue pois tinha sofrido um acidente, e a gente ficou pensando, nossa que situação coitada dessa família. Enfim, e só tava eu e minha filha viajando quando a gente descobriu umas 3 horas depois, foi uma coisa horrorosa, ela ficou a ela tava no interior ainda para os primeiros socorros, e depois de uns 4 dias, a família resolveu transferir para São Paulo. E nessa transferência para São Paulo ela teve um inchaço cerebral e isso desestabilizou e ela teve morte cerebral no mesmo dia que ela chegou em São Paulo. E quando ela tava nesse processo de diagnosticar morte cerebral a gente tava assim, em desespero né, porque a gente não podia acreditar que aquilo tava acontecendo.

Entrevistador: E aí você ficou sabendo da morte?

A gente... as pessoas falavam pelo WhatsApp o que estava acontecendo, que ela teve morte cerebral e a gente mandava mensagem para mãe, porque os pais não divulgaram, não queriam dizer que ela teve morte cerebral, mesmo porque eles não queriam acreditar nisso e a gente também não acreditava a gente queria que... insistir que ela não tivesse morrido e tem aquele processo todo que eles fazem os testes para saber se realmente deu a morte cerebral... e a gente não queria que chegasse o dia desses testes, a gente queria que ficasse pra amanhã, e pra amanhã e pra amanhã... minha filha escrevia para mãe dela e dizia: a Maria nunca ia desligar os aparelhos se fosse por você tia, ela nunca ia desligar e a gente ficava rezando para que ela não 
desligasse mesmos aparelhos... porque a gente achava que ela podia reagir, porque ela era forte , porque a gente conhecia ela muito bem. Então a gente tinha uma esperança muito grande que ela ia reagir e acho que no terceiro dia a mãe... eles conversaram e então decidiram que iam desligar os aparelhos, porque eles poderiam doar os órgãos.

E foi muito ruim, porque a gente não podia fazer nada... era uma situação horrorosa e antes mesmo de ser anunciado que eles iam desligar os aparelhos as pessoas começaram a postar coisas na internet, no Facebook principalmente, foto de... "tô com saudade, foi bom ser sua amiga, nunca esqueça"... enfim, milhões de mensagens e a gente... minha filha principalmente escrevia mensagem para os amigos dizendo "para com isso! ela não morreu, ela não morreu ainda, ela não morreu"... a gente até acabou criando uma certa inimizade com algumas pessoas que fizeram isso antes da hora e foi horrível, e então ela teve realmente, foi diagnosticada a morte cerebral e fizeram a doação dos órgãos e aí a gente viu aquela... aquela... um monte de mensagens na internet e pessoas querendo dizer que eram amigas dela e postando fotos, e... sei lá, eu achei um tanto desnecessário, triste, tanto é que na minha casa... a gente não postou nada, a gente não quis postar nada em relação a ela, acho que a tristeza era muito particular, e não ia aliviar a dor dividindo isso com as pessoas. Acho que é uma coisa muito triste para ficar... sei lá, você posta uma coisa que você perdeu uma pessoa, que você está de luto, e as pessoas vão ficar te escrevendo "a, que pena, ela morreu e sei lá o que", quando na verdade você não quer ouvir nada de outras pessoas, porque acho que as outras pessoas não sabem da sua dor, não sabem o que aquilo significava para você. E hoje, quando eu vejo, o pai dela sempre posta fotos, fotos no dia das crianças, fotos...

- Entrevistador: Mas o pai posta no perfil dele ou dela?

No perfil dele e posta fotos dela, assim, em datas comemorativas: natal, dia das crianças, enfim... e é horrível, é ruim ver a foto dela, sei lá, não é... eu acho que as pessoas cada dia comentam menos e... e assim, acho estranho, porque os pais... o pai é um pouco diferente, mas a mãe, ela age como se a filha não tivesse morrido e, ela consola as pessoas, mas ela não posta nada no Facebook, ela não posta nada no Instagram. Mas o pai constantemente posta, pelo menos umas duas vezes por mês ele posta alguma coisa dela e não é confortável ver a foto dela, sei lá, eu não gostaria que ele postasse mais as fotos dela.

- Entrevistador: E o perfil dela?

Teve um dia que eu tava olhando meu Facebook e cliquei no nome dela e apareceu o perfil dela e, eu não tive coragem de olhar, eu achei que... sei lá, eu acho muito triste. Eu nem quis ver se 
tinha alguma coisa sabe, que as pessoas postam, tipo homenagem, não sei. Eu não sei o que tem no perfil dela.

- Entrevistador: Mas está lá?

Agora eu não sei, mas estava lá sim. Eu já fiquei imaginando, sabe? Algumas pessoas dizendo... eu já ouvi algumas histórias que as pessoas ficam alimentando o perfil de uma pessoa que foi embora, então, as pessoas postam muitas coisas, colocam fotos, principalmente no aniversário da morte da pessoa, e eu acho isso muito triste. Eu acho que, a mãe da Maria fala que ela não precisa ser esquecida, ela tem que ser lembrada, como se fosse uma pessoa que fosse morar no exterior, que você vai ver, quem sabe, ou talvez não veja mais, mas que você sente saudade. Mas eu não consigo pensar na Maria dessa forma, eu acho que, sei lá, é estranho... Não acho confortável ver uma foto dela estampada no Facebook.

- Entrevistador: Então, você acha que interagir com o perfil poderia não ser positivo em relação a ideia de luto?

Eu acho que me fez mal e... eu vejo que outras, por exemplo na minha casa, ninguém comenta nada. Às vezes eu mostro uma foto, as vezes eu tô olhando fotos antigas no computador e acho alguma coisa dela e mostro para os meus filhos. E eles, tipo, não gostam de ver, não querem lembrar, porque acho que o que ficou foi muito sofrimento repentino, e sofrimento que demorou muito para acabar. Então, eu acho que ficou muito isso, do momento mais crítico, sofrido, que, sei lá, acho que, pelo menos na minha casa, a gente não quer lembrar disso... acho que, ver uma foto dela estampada no Facebook, no Instagram, acho que remete, ao sofrimento, àquele tempo que foi ruim. A gente não pensa no momento bom, a gente pensa no que de ruim aconteceu com ela.

- Entrevistador: E vocês participaram do funeral?

Sim, eu não fui no cemitério. Minha filha foi. E como todo mundo da escola, eram muitos amigos, e eu só fui na missa de sétimo dia, e foi muito triste. Foi triste e eu me sentia... olhava para a mãe dela e me sentia pior que ela, e olhava para minha filha e pensava que podia ser minha filha, e olhava para a Maria e imaginava a Maria... ficou um buraco ali. E olhava para a mãe e pensava: como que ela tá aguentando tudo isso? Algumas pessoas criticavam ela, porque a gente não sabia se ela tava dopada, enfim, a gente não sabia se ela tava em choque. Porque ela ficava praticamente acolhendo as pessoas que estavam no lugar. Então ela dizia para as pessoas: ta tudo bem, ela ta num lugar bom, ela não ta sofrendo, ela é uma estrelinha. Enfim, 
ela falava coisas que... era um sentimento de como se ela tivesse consolando mesmo. Mas não sentia que aquilo era bom, enfim, ela podia estar em choque ou dopada, aquilo era estranho. $\mathrm{O}$ pai, muito pelo contrário, chorava muito. Enfim, acho que ali, eu percebia que tinha muitas pessoas que choravam como se quisessem mostrar que estavam chorando. Outras pessoas choravam porque era triste mesmo toda aquela história. Não sei, eu acho que foi... não pensando só numa menina de 15 anos que morreu. Mas para a gente não era só uma menina, era uma pessoa muito especial.

O que deixou a situação muito pior foi: olha, ela vai ser operada, olha tá estável, tá estável então vamos transferir para São Paulo, e a gente tinha essa sensação de: não transfere para São Paulo. Mas as pessoas têm uma ideia de: vamos para o Einstein, vamos para o São Luiz, e lá vai dar tudo certo, e foi quando eles transferiram ela que ela teve essa instabilidade e começou a inchar o cérebro de novo. E quando eles falaram que, que não tinha mais jeito... antes disso acontecer tinha um pai da escola, um pai representante que era amigo do casal, e ele dava as informações para todo mundo no grupo, então esse pai falava: olha, ela tá mal, olha, ela não vai sobreviver. E ele falava coisas no grupo que revoltavam as pessoas que tinham muita proximidade dela. Outras pessoas que não tinham tanta proximidade falavam: olha, a gente tá rezando pela família... que ela vá em paz... Quando as pessoas escreviam "que ela vá em paz”, a gente pensava, tipo, ela não é sua filha, ela não é nada sua.

- Entrevistador: mas ela já tinha tido a morte cerebral aí?

Não, ainda não. Ainda não tinha diagnosticado. Ela tava com um inchaço cerebral, mas ainda não tinha sido diagnosticado. Quem falava da gravidade da coisa era uma pessoa que não tinha conhecimento nenhum. Então ele só dizia "ouvi isso dos médicos", "ouvi isso dos médicos", quando na verdade os pais... a gente não sabe se os pais também não queriam aceitar, e a gente também não queria aceitar, então a gente tinha essa...

A escola inteira divulgava coisas no Snap, no Stories, no Facebook, postando coisas assim “onde vai ser o enterro?”, “que horas vai ser o funeral?”, e a gente, assim, quando você não tem uma nota oficial "foi diagnosticado morte cerebral", você espera, porque você tem uma esperança ainda, não importa... a gente tinha essa esperança. Mas esse pai da escola, a gente o achava muito insensível, e ele ganhou inimizade de todas as pessoas que tinham proximidade da Maria, e ele é um homem hoje muito odiado porque ele fez coisas que ele não tinha direito de fazer.

- Entrevistador: tipo? 
Ele não tinha direito de dizer que ela estava morta, eles divulgaram onde ela seria velada. Esse tipo de coisa, acho que ele foi desrespeitoso com a família, foi péssimo com todas as pessoas na verdade. Porque ela não era um pedaço de carne, ela era uma pessoa, que tipo... amavam ela.

Eu acho que nesse momento as pessoas não têm que falar coisas que não tem certeza. Precisam ter cuidado para dar uma notícia ruim.

- Entrevistador: E quando tiveram certeza? O que foi a "nota oficial”?

A nota oficial foi quando eles esperaram 24 horas, e eles fizeram um teste para saber se tinha dado morte cerebral, e os médicos achavam que provavelmente tinha dado morte cerebral, mas eles esperaram 24 horas para ter certeza. E nesse caso, repetiram, e talvez porque o cérebro tava desinchando. Então eles repetiram depois de 24 horas e constataram a morte cerebral, mesmo porque não tinha muito mais tempo para a retirada dor órgãos, então nesse momento era como se fosse... era um momento de tristeza, mas um alivio também, aí não ficava toda hora divulgando uma coisa e depois outra. E quem fez a nota oficial... essa nota veio, não sei se foi da escola... a gente soube através da mãe, mas para as pessoas todas veio através da escola que notificou... aí sim, acabou, acalmou os ânimos, tipo, não tem mais jeito. Mas essa forma de você informar uma situação como essa, não dá para ficar dizendo, "olha, agora morreu”, "olha, agora não morreu". Isso durou uns quatro dias de angustia, as pessoas rezando a noite toda. A escola toda em comoção. Como te disse, também tinha aquela coisa de sensacionalismo, as pessoas querem aparecer achando que... que isso, queriam ganhar não fama, mas um espaço se aproveitando de uma situação triste como essa, isso era o mais revoltante. É isso... 